\title{
Assessing Potential Exposure from Truck Transport of Low-level Radioactive Waste to the Nevada Test Site
}

\author{
prepared by \\ Julianne J. Miller, David S. Shafer, Karen J. Gray, Bruce W. Church, \\ Scott A. Campbell, and Barbara A. Holz
}

submitted to

Nevada Site Office

National Nuclear Security Administration

U.S. Department of Energy

Las Vegas, Nevada

AUGUST 2005

Publication No. 45208 
Reference herein to any specific commercial product, process, or service by trade name, trademark, manufacturer, or otherwise, does not necessarily constitute or imply its endorsement, recommendation, or favoring by the United States Government or any agency thereof or its contractors or subcontractors. The views and opinions of authors expressed herein do not necessarily state or reflect those of the United States Government or any agency thereof.

This report has been reproduced directly from the best available copy.

Available for sale to the public, in paper, from:

U.S. Department of Commerce

National Technical Information Service

5285 Port Royal Rd.

Springfield, VA 22161

phone: 800.553 .6847

fax: 703.605 .6900

email: order@ntis.gov

online ordering: http://www.osti.gov/ordering.htm

Available electronically at http://www.doe.gov/bridge

Available for a processing fee to the U.S. Department of Energy and its contractors, in paper, from:

U.S. Department of Energy

Office of Scientific and Technical Information

P.O. Box 62

Oak Ridge, TN 37831-0062

phone: 865.576 .8401

fax: 865.576 .5728

email: reports@adonis.osti.gov 


\title{
Assessing Potential Exposure from Truck Transport of Low-level Radioactive Waste to the Nevada Test Site
}

\author{
prepared by \\ Julianne J. Miller, David S. Shafer, Karen J. Gray, Bruce W. Church, \\ Scott A. Campbell, and Barbara A. Holz \\ Division of Hydrologic Sciences \\ Desert Research Institute \\ University and Community College System of Nevada
}

Publication No. 45208

submitted to

Nevada Site Office

National Nuclear Security Administration

U.S. Department of Energy

Las Vegas, Nevada

AUGUST 2005

The work upon which this report is based was supported by the U.S. Department of Energy under Contract \#DE-AC52-00NV13609. Approved for public release; further dissemination unlimited. 
THIS PAGE INTENTIONALLY LEFT BLANK 


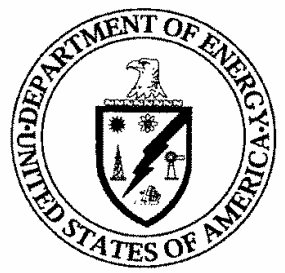

\author{
Department of Energy \\ National Nuclear Security Administration \\ Nevada Site Office \\ P.O. Box 98518 \\ Las Vegas, NV 89193-8518
}

MAY 62005

Julianne Miller, Principal Investigator

Desert Research Institute

755 E. Flamingo Road

Las Vegas, NV 89119-7363

Dear Julianne:

FINAL REPORT, ENTITLED: ASSESSING POTENTIAL EXPOSURE FROM TRUCK TRANSPORT OF LOW-LEVEL RADIOACTIVE WASTE TO THE NEVADA TEST SITE

We thank you and your associates for completing the subject report and request that this letter be published with the report.

The Desert Research Institute (DRI) has turned a vague concept, measurement of the actual gamma radiation exposure from truck transporting low-level radioactive waste to the Nevada Test Site, into reality. This document gives the reader an important insight into the complexities associated with the measurement of gamma radiation and how these measurements relate to the exposure to a member of the public. The results of this study indicate that individual truck and cumulative exposure measurements were well below relevant Department of Transportation and Environmental Protection Agency standards.

Although the Department of Energy, National Nuclear Security Administration Nevada Site Office (NNSA/NSO) funded this study and has reviewed drafts of this report, it is important to understand that DRI is solely responsible for the content of this report. The NNSA/NSO will now initiate a process to consider the recommendations contained in the report.

Again, thank you for your dedication and hard work.

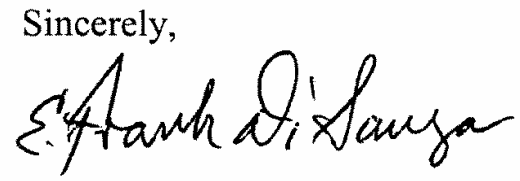

E. Frank Di Sanza, Director

Waste Management Division 
THIS PAGE INTENTIONALLY LEFT BLANK 


\section{EXECUTIVE SUMMARY}

The United States (U.S.) Department of Energy (DOE) Nevada Test Site (NTS) is one of two regional sites where low-level radioactive waste (LLW) from approved DOE and Department of Defense generators is disposed of by shallow land burial. In fiscal year (FY) 2003, more than $91,000 \mathrm{~m}^{3}\left(3.2\right.$ million $\left.\mathrm{ft}^{3}\right)$ of LLW were transported by truck to the NTS. Over $85,000 \mathrm{~m}^{3}$ (3.0 million $\left.\mathrm{ft}^{3}\right)$ were disposed of in FY 2004, driven in part by the accelerated closure of DOE Environmental Management (EM) sites such as Mound, Fernald, and Rocky Flats. The DOE and Department of Transportation (DOT) regulations ensure that radiation exposure from truck shipments is negligible. Nevertheless, particularly in rural communities, there is perceived public risk about cumulative exposure, especially when LLW transportation routes and the main highway through towns are the same. The DOE, National Nuclear Security Administration Nevada Site Office (NNSA/NSO), which manages the NTS, has agreed with the State of Nevada to restrict transport of LLW through the Las Vegas metropolitan area. Consequently, LLW generators primarily use highways through rural parts of Nevada and western Utah to reach the NTS.

The NNSA/NSO and other DOE offices have provided information on potential exposure to members of the public from LLW trucks as part of public outreach activities. However, based on literature searches and discussion with other researchers in the transportation field, nearly all of the information is based on calculated versus measured exposures, although measurements of trucks are made with portable, hand-held instruments when drivers arrive at such facilities as the Area 5 Radioactive Waste Management Complex (RWMC) or the Area 3 Radioactive Waste Management Site (RWMS) on the NTS. To help better address public concerns about potential exposure from LLW trucks, a stationary and automated array of four pressurized ion chambers (PICs) was established for LLW trucks to pass through just before they reached the NTS. The PICs were positioned $1.0 \mathrm{~m}(3.3 \mathrm{ft})$ from the truck trailer at a height of $1.5 \mathrm{~m}(5.0 \mathrm{ft})$ to simulate conditions of a citizen standing on a sidewalk next to a LLW truck on a standard two-lane highway in the U.S., and to be representative of the exposure of chest organs for a "Reference Man" using the Snyder-Fisher model of an adult human. The use of four PICs (two on each side of a truck) was to investigate, account, and correct for nonuniformity where gamma radiation levels from waste packages varied from side to side, and from front to back in the truck trailer. In addition to the PICs, photoacoustic sensors, positioned between the PICs on each side of the array, were used to detect when a truck entered and departed the array. Data from the PICs and photoacoustic sensors were recorded on dataloggers. All instruments were solar powered. Automating the array provided an objective and consistent means to measure and calculate exposure to gamma radiation.

Each PIC was calibrated by collecting readings from exposure to a known 189.2 micro $(\mu) \mathrm{Ci}^{137} \mathrm{Cs}$ source. A calibration was first conducted in the field, and then the same PICs and dataloggers were calibrated again in the laboratory at the Desert Research Institute in Las Vegas. Last, an independent calibration was performed on one of the PICs by the Environmental Measurements Laboratory (EML), U.S. Department of Homeland Security, in New York, with a ${ }^{226}$ Ra source. The EML calibration showed only a three percent difference in energy response, within the tolerance range for a variation in the detector energy for a PIC when comparing calibrations with two difference sources. However, because of periodic under-response in voltage and background measurements of 
one of the PICs during operation of the array in the field, only the measurements from three PICs were used in determining background for calculating the "net exposure" from each truck.

A letter from the Waste Management Division Director at NNSA/NSO to all approved generators requested their truck drivers to participate in the study and provided instructions for using the PIC array. However, because DOE could not contractually require waste generators to participate, the database is biased to voluntary participants. Drivers parked their truck in a marked "footprint" within the array and recorded shipment information, including date, time, and Waste Shipment Identification Number (WSIN), into a logbook located at the PIC array. Data on 1,012 truck shipments were collected between February and December 2003, representing nearly 47 percent of all LLW truck shipments to the NTS during the study period. A slightly larger number of trucks passed through the array, but insufficient data were recorded by truck drivers to match PIC readings to a particular truck and WSIN. Consequently, these measurements were not included in the database presented herein. The remote location of the site, and the fact that drivers could arrive at the site 24 hours per day, made it infeasible and cost prohibitive to have a person present at the PIC array to direct drivers to use the array.

The dataloggers were programmed to continuously run, with PIC measurements collected at 5-sec intervals. The dataloggers were programmed to analyze these data at 2-min intervals, and record, for each 2-min interval, (1) the maximum 5-sec microRoentgens per hour $(\mu \mathrm{R} / \mathrm{h})$ value, (2) the minimum 5-sec $\mu \mathrm{R} / \mathrm{h}$ value, and (3) the average of all 5-sec PIC readings. The photoacoustic sensors detected when a truck passed through the PIC array during a 2-min interval. It was assumed that it would take the driver longer than two minutes to enter the required information into the array logbook; however, particularly when the minimum recorded PIC value was at background, there was evidence that the truck may not have remained within the array for the entire 2-min period. In these cases, the 2-min averaged PIC readings would incorporate both measurements from the truck as well as background readings before or after the truck was in the array. As a consequence, the maximum PIC values were determined to be the most consistent and reliable measurements of an actual truck. Thus, the highest maximum value from the four PICs during a 2-min interval was selected as the gross measurement for the truck. Use of the maximum PIC reading was also consistent with procedures used at the Area 3 RWMS and Area 5 RWMC for recording measurements for trucks with portable instruments at the NTS.

Readings taken every two minutes when trucks were not present in the array were used to calculate two background values in military time: from 1946 (7:46 pm) to $0744 \mathrm{~h}$ (7:44 am) and 0744 to $1946 \mathrm{~h}$. For consistency in using maximum exposure measurements from the trucks, the average of the maximum background values obtained during the specific 12-h window when a truck arrived at the PIC array, and the standard deviation of the background values, were subtracted from the gross reading of the truck to obtain net exposure values for each truck. Overall, background readings could vary from approximately 9 and $40 \mu \mathrm{R} / \mathrm{h}$, although typically background readings ranged between 10 and $15 \mu \mathrm{R} / \mathrm{h}$.

In addition, for each of the trucks, the WSIN was used to determine the route its driver used to reach the NTS so that potential exposures could be apportioned to particular 
towns along the routes. There were six potential routes during the study period that drivers traveling through Nevada or western Utah could have used to reach the NTS. However, for the shipments in the database, only four of the routes were used. Measurements from 10 of the 18 waste generators who sent LLW to the NTS during the study period contributed to the database. Although no data were collected from an additional eight generators, the 10 participating generators accounted for the vast majority ( 92 percent) of the waste shipments to the NTS when the PIC array was operating. Because of the voluntary nature of the study, the names of individual generators are not provided in the report.

Although manufacturer specifications for the Reuter-Stokes, Model RSS-131, PIC used in this study stated that the instrument would read to $1,000 \mu \mathrm{R} / \mathrm{h}$, it was subsequently found that a second channel on the PIC had to be used for measurements over $800 \mu \mathrm{R} / \mathrm{h}$, and even then, pursuant to the manufacturer, the "analog sensitivity output is invalid" for measurements between 800 and 1,000 $\mu \mathrm{R} / \mathrm{h}$ (Reuter-Stokes, 2001). Of the 1,012 trucks measured, 59 had gross gamma readings at the PIC array greater than $800 \mu \mathrm{R} / \mathrm{h}$.

To rectify this situation, when a record of $800 \mu \mathrm{R} / \mathrm{h}$ or greater occurred, the WSIN from the truckers' logbook was used to find the specific waste manifest sheet from the RWMC or RWMS records. The waste manifest sheets include the hand-held radiation instrument readings made by the LLW radiological control technicians (RCTs) at the RWMC and RWMS, using a Ludlum Model 3 gamma detector. The RCTs routinely record the gamma radiation measurements of the highest readings at the surface of the truck trailer, at $0.3 \mathrm{~m}(1.0 \mathrm{ft})$ distance from the trailer, at $1.0 \mathrm{~m}(3.3 \mathrm{ft})$ distance from the trailer, and at the truck cab, approximately $3.0 \mathrm{~m}(10.0 \mathrm{ft})$ distance from the trailer. In all, data from 77 trucks, including the 59 recorded at the PIC array, with gross measurements greater than $800 \mu \mathrm{R} / \mathrm{h}$, were examined to evaluate whether the $1.0 \mathrm{~m}(3.3 \mathrm{ft})$ measurements at the Area 3 RWMS and the Area 5 RWMC could be substituted for the trucks with measurements greater than $800 \mu \mathrm{R} / \mathrm{h}$ at the PIC array.

Measurements at $1.0 \mathrm{~m}(3.3 \mathrm{ft})$ and at $0.3 \mathrm{~m}(1.0 \mathrm{ft})$ were normalized to readings taken on contact with the truck. Taking the thickness of the truck wall into account, the actual distances plotted were $0.022 \mathrm{~m}(0.072 \mathrm{ft}), 0.322 \mathrm{~m}(1.07 \mathrm{ft})$, and $1.022 \mathrm{~m}(3.35 \mathrm{ft})$. The data were then evaluated to see if the slope of the resulting curve (gross gamma reading versus distance) and its standard deviation would suggest that the data behaved in a manner such that readings at $1.0 \mathrm{~m}(3.3 \mathrm{ft})$ were predictable. The standard deviation at

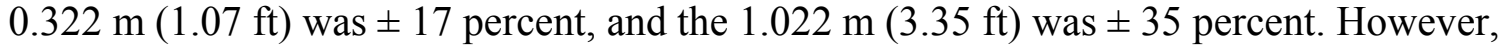
the slope of the decrease of radiation intensity as a function of increasing distance was much lower, or "slower," than would be predicted than if the trucks had been treated as point or even line sources. The authors recommend further study on these phenomena. Based on the relatively low standard deviation, the measurements at the Area 5 RWMC at $1.0 \mathrm{~m}(3.3 \mathrm{ft})$ were used in the database for those trucks that measured greater than $800 \mu \mathrm{R} / \mathrm{h}$ at the PIC array. Another check of consistency between measurements taken at the PIC array and measurements taken at the RWMC was that, in all but one case, trucks measured at the PIC array that produced gross exposure values exceeding $800 \mu \mathrm{R} / \mathrm{h}$ also produced values at the RWMC that exceeded $800 \mu \mathrm{R} / \mathrm{h}$ as well, with the one exception at the $\mathrm{RWMC}$ reading $750 \mu \mathrm{R} / \mathrm{hr}$. 
For analyzing the data, five scenarios appropriate for rural transportation routes were developed, with the $1.0 \mathrm{~m}(3.3 \mathrm{ft})$ distance between the member of the public and the truck, and the time of exposure ranging from $15 \mathrm{sec}$ to $8 \mathrm{~h}$. For each scenario, the number of trucks that could have contributed to exposure was determined, and the total potential exposure based on the PIC array records for the trucks that traveled those routes to the NTS was calculated. Of the four routes used by trucks during the study period, nearly 58 percent passed through the towns of Tonopah, Beatty, and Goldfield, NV, before reaching the NTS. At both Ely, NV, and Tonopah, there are highway junctions where truck routes converge. Furthermore, once a truck driver reaches Ely, the only reasonable travel route to the NTS is through Tonopah, Beatty, and Goldfield because of LLW truck transport restrictions through the Las Vegas Valley.

For nearly half of the trucks measured at the PIC array ( 483 or 47.7 percent), the net exposure at a distance of $1.0 \mathrm{~m}(3.3 \mathrm{ft})$ was less than or equal to $0.0 \mu \mathrm{R} / \mathrm{h}$, meaning that the truck was indistinguishable from variations in background and represented no potential exposure to a member of the public. An additional 206 trucks had exposures greater than zero, but equal to or less than $1 \mu \mathrm{R} / \mathrm{h}$. Finally, nearly 80 percent of the population of trucks (802 of 1,012 ) had net exposures less than or equal to $10 \mu \mathrm{R} / \mathrm{h}$. Although there are no shipping or exposure standards at $1.0 \mathrm{~m}(3.3 \mathrm{ft})$ distance, one relevant point of comparison is the DOT shipping standard of 10 millirems (mrem) per hour at $2.0 \mathrm{~m}(6.6 \mathrm{ft})$ distance. Assuming a one-to-one correspondence between Roentgens and Rems, then 903 trucks (89.2 percent of the trucks measured) had net exposures no greater than one percent of the DOT standard at $1.0 \mathrm{~m}(3.3 \mathrm{ft})$. In actuality, of course, had the distance at which the trucks were measured increased to $2.0 \mathrm{~m}(6.6 \mathrm{ft})$ where the DOT shipping standard is established, the net exposure would be even less because of the increase in distance, although based on the empirical data from the NTS, at a rate of decrease that may be slower than for either a point or line source. The highest value recorded at $1.0 \mathrm{~m}(3.3 \mathrm{ft})$ distance $(11,970.9 \mu \mathrm{R} / \mathrm{h}$, or $11.9 \mathrm{mR} / \mathrm{h}$ ) was the only truck with a value greater than $10.0 \mathrm{mR} / \mathrm{h}$.

Previous studies on potential exposure to the public from transporting LLW to the NTS either relied on calculated exposures (Davis et al., 2002) or were based on a small population of trucks (e.g., 88) where a relatively high-background value of $50 \mu \mathrm{R} / \mathrm{h}$ (background value measured at the LLW disposal sites) was subtracted from the gross reading of the truck trailer as measured by portable, hand-held instruments (Gertz, 2001). This background value is considerably higher than values at the PIC array or at towns along transportation routes in the region. Nevertheless, if the dataset described herein was analyzed for net exposure using the $50-\mu \mathrm{R} / \mathrm{h}$ background value, then 84.5 percent of the trucks would be below background. This is a result not altogether different than the estimate made in Gertz (2001).

Cumulative exposures were calculated for the population of trucks that went through particular towns based on five exposure scenarios. These scenarios assume, however unlikely, that the same individual, or "reference man," was exposed to all the trucks measured in the study that traveled along particular transportation routes. For the cumulative exposure measurements, comparisons were made to exposure limits to the public in 10CFR834, Subpart B, "Radiation Dose Limits for Members of the Public," which, excluding radon and medical exposures, limits members of the public to an exposure no greater than $100 \mathrm{mrem} / \mathrm{y}$ from any licensed facility. 
The cumulative exposure calculations highlight the nonGaussian nature of the data, with measurements dominated by a small percent of the trucks (5.4) with net exposures rates greater than $1,000 \mu \mathrm{R} / \mathrm{h}$, or $1 \mathrm{mR} / \mathrm{h}$. A scenario that has been commonly used by the NNSA/NSO is that of a person walking adjacent to a LLW truck for a period of $15 \mathrm{sec}$ at a distance of $2.0 \mathrm{~m}(6.6 \mathrm{ft})$. In this study, this scenario was examined at a distance of $1.0 \mathrm{~m}$ $(3.3 \mathrm{ft})$. Previously evaluations had been based on extrapolations of calculated truck exposures at $1.0 \mathrm{~m}(3.3 \mathrm{ft})$ to $2.0 \mathrm{~m}(6.6 \mathrm{ft})$ by treating the truck as either a line or a point source. As an example, if a person was along the side of the road when each of the 42 trucks measured from Route 2 went through Amargosa Valley, assuming the 15-sec exposure of Scenario 1, his or her cumulative exposure would be $3.0 \mu \mathrm{R}$. However, Amargosa Valley is a good example of the sensitivity of the higher measurements on total cumulative exposure. If the truck with the highest net exposure reading of $259.2 \mu \mathrm{R}$ over a one-hour period is removed from the total net exposure calculation, then the cumulative exposure for Scenario $1(15 \mathrm{sec})$ is reduced to $2.0 \mu \mathrm{R}$, or only 66 percent of the original cumulative exposure rate.

The probability of an individual receiving exposure from a truck, rather than a "reference man" cumulative exposure, may be a more meaningful perspective to an individual living in one of the communities along the transportation routes. For each of the five scenarios, the actual amount of time when an exposure might occur is comparatively short, and there is far more time when a LLW truck is not present along a route. However, for the purposes of this study, the assumption was made that an individual was present within $1.0 \mathrm{~m}(3.3 \mathrm{ft})$ of a truck when it passed through town; and thus, the potential for an exposure to a LLW truck was assumed to exist.

As previously discussed, a small number of trucks contribute the majority of potential cumulative exposures, but the probability of being exposed to one of those trucks is low. For example, of the 587 LLW trucks that traveled through Tonopah, 340 of these trucks had net exposure rates greater than $0.0 \mu \mathrm{R} / \mathrm{h}$, and 54 of the trucks had net exposure rates greater than or equal to $1,000 \mu \mathrm{R} / \mathrm{h}$. This results in the probability of an individual in Tonopah receiving a potential net exposure from any single truck to be 0.58 , and to a truck with a net exposure rate greater than or equal to $1,000 \mu \mathrm{R} / \mathrm{h}$ to be only 0.09 .

In conclusion, although this study suggests that members of the public may receive exposure that can be measured from a small percentage of LLW trucks coming to the NTS, the vast majority of trucks ( 89.2 percent) represent no more than one percent of the relevant standards (e.g., the DOT shipping exposure standard of $10 \mathrm{mrem} / \mathrm{h}$ at $2 \mathrm{~m}$ ). For nearly 50 percent of the trucks measured, there would be no net exposure.

The dataset collected for this study is the largest the authors are aware of for systematically collected exposure data for LLW truck shipments, especially when they are in transit. In addition, because this study was based on measurements rather than calculations of exposure, recommendations for future studies of this type are provided. 


\section{ACKNOWLEDGMENTS}

In addition to the authors, other DRI personnel contributed to this study including Craig Shadel, Lynn Karr, Stacey Sedano, Tammy Kluesner, Amy McKinney, and Kristen Self. DRI appreciates the assistance of Bechtel Nevada (BN) Waste Management Operations for providing copies of Waste Shipment Identification Numbers for trucks that passed through the PIC array as well as records of surveys of trucks taken at the Area 5 Radioactive Waste Management Complex and the Area 3 Radioactive Waste Management Site on the Nevada Test Site. Rose Denton of BN provided access and assistance with the Low-level Waste Information System for NTS that provided information on shipments per month. Lee Stevens of Navarro Engineering provided information on the number of shipments and approved generators, volumes of waste disposed of, and transportation routes. Last, the participation of waste generators was obviously critical to the study. The study was funded by the Waste Management Division, National Nuclear Security Administration Nevada Site Office through contract DE-AC52-00NV13609. 


\section{CONTENTS}

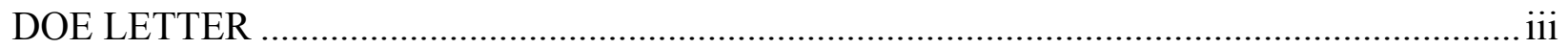

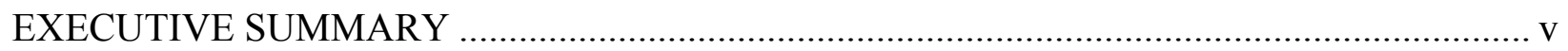

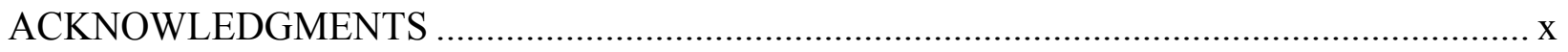

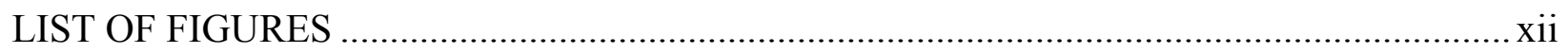

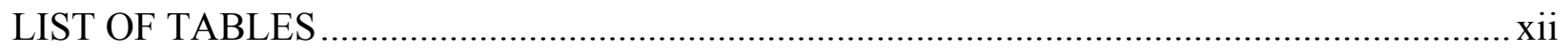

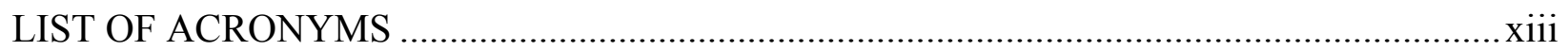

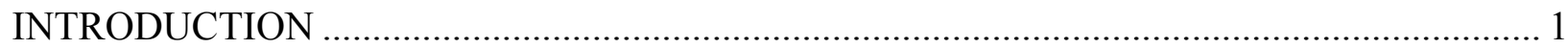

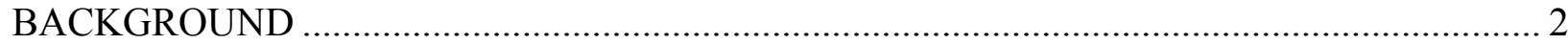

The Role of the NTS as a Regional LLW Disposal Site..................................................... 2

Major Truck Routes and Travel Restrictions for LLW Trucks.............................................. 2

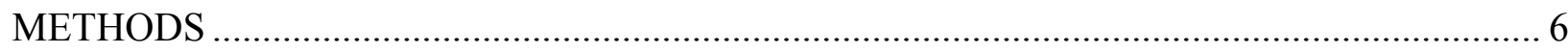

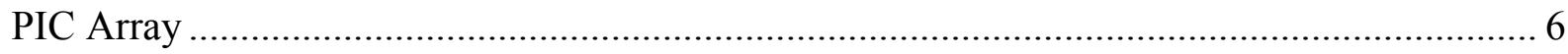

Collecting and Processing Data from the PIC Array ……................................................... 8

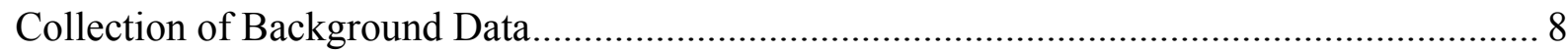

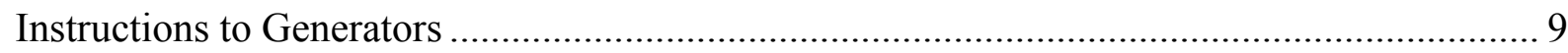

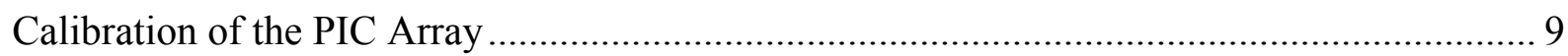

Data Collection, Management, and Analysis.................................................................... 12

Criteria for Identifying a Truck in the PIC Array ............................................................... 13

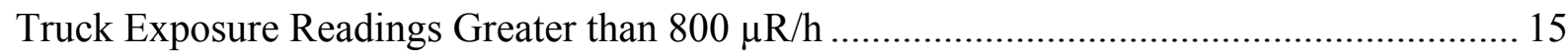

Reduction in Radiation Intensity as a Function of Distance from LLW Trucks ..................... 16

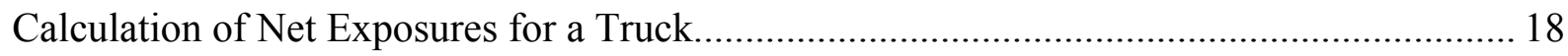

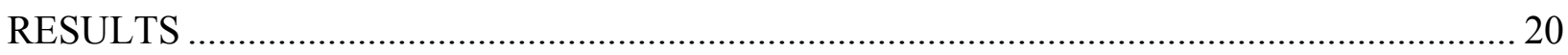

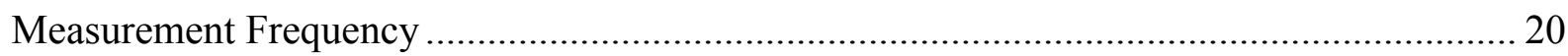

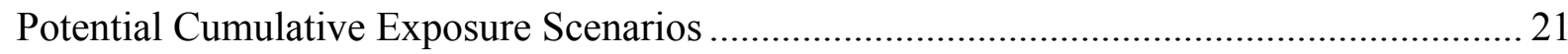

Potential Individual Exposure Probabilities......................................................................... 26

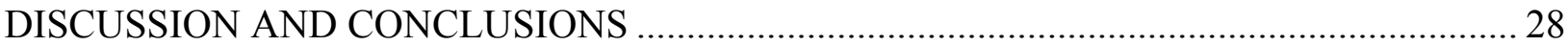

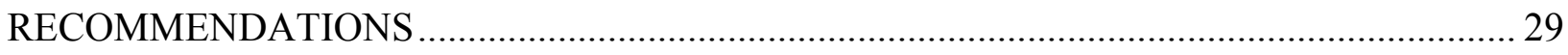

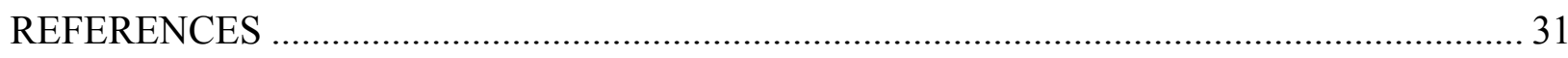

APPENDIX: Gross, Net, and Adjusted Net Measurements for LLW Trucks............................ A-1 


\section{LIST OF FIGURES}

1. LLW transportation route map to the NTS. Las Vegas is located $105 \mathrm{~km}$ (65 mi) southeast of the entrance of the NTS near Mercury, where the PIC array was

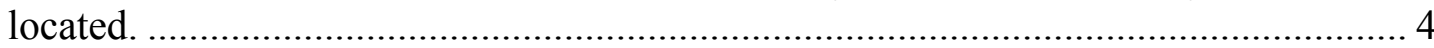

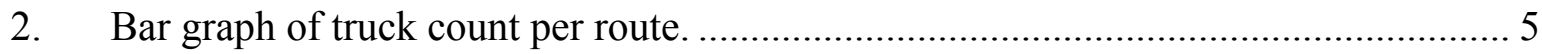

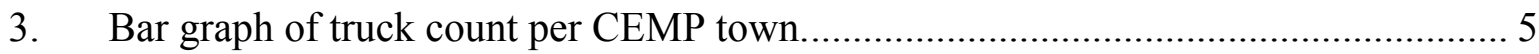

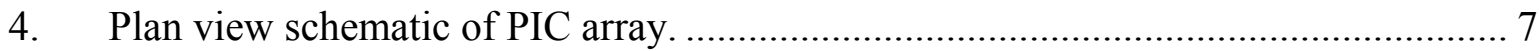

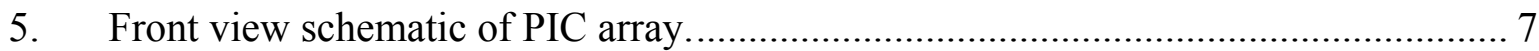

6. A flatbed truck in the PIC array during the setup of the instrumentation................... 8

7. Maximum readings from PIC 2B on May 5, 2003, plotted as a function of

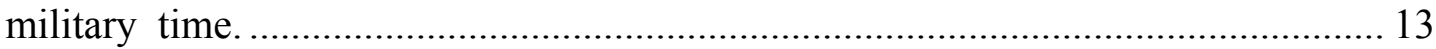

8. Rates of radiation intensity reduction as a function of increasing distance............... 17

9. Net exposure measurement frequency for all 1,012 trucks measured during the study using the average background and standard deviation. .................................... 20

10a. Measurement frequency of the 384 trucks that traveled through Pahrump, NV (Route 1), compared to net exposure ranges in $\mu \mathrm{R} / \mathrm{h}$.............................................. 23

10b. Measurement frequency of the 42 trucks that traveled through Amargosa Valley, NV (Route 2), compared to net exposure ranges in $\mu \mathrm{R} / \mathrm{h}$.

10c. Measurement frequency of the 427 trucks that traveled through Delta, UT, and Tonopah, NV (Route 5), compared to net exposure ranges in $\mu \mathrm{R} / \mathrm{h}$......................... 24

10d. Measurement frequency of the 162 trucks that traveled through Salt Lake City, UT, and Tonopah and Ely, NV (Route 6), compared to net exposure ranges in $\mu \mathrm{R} / \mathrm{h}$...... 25

10e. Measurement frequency of the 587 trucks that traveled through combined Tonopah, $\mathrm{NV}$, total (Routes 5 and 6) compared to net exposure ranges in $\mu \mathrm{R} / \mathrm{h}$.

\section{LIST OF TABLES}

1. Six major trucking routes used for transporting LLW to the NTS.............................. 3

2. Results of field calibration of the PICs in the array, as well as laboratory calibrations

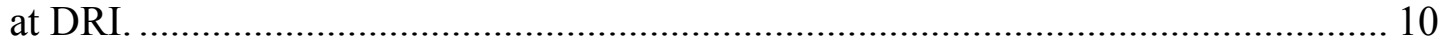

3. Solid-state voltage outputs for the PICs.............................................................. 11

4. Sample Microsoft Access database format for LLW truck transportation exposure data collected on dataloggers at the PIC array. .......................................................... 12

5. The net exposure results for a subset of trucks that passed through the PIC array between July 1 and July 8, 2003.......................................................................... 19

6. The absolute number of trucks per increment of net exposure. …………………...... 21

7. Potential exposure scenarios for members of the public in rural towns in Nevada and Utah along transportation routes to the NTS............................................................. 22

8. Total exposures $(\mathrm{mR})$ for each scenario by route and town..................................... 23

9. Probability of a potential net exposure to an individual within a specific town from any single truck or to a truck with a net exposure greater than or equal to $1,000 \mu \mathrm{R} / \mathrm{h}$. 


\section{LIST OF ACRONYMS}

BN Bechtel Nevada

CEMP Community Environmental Monitoring Program

DoD U.S. Department of Defense

DOE U.S. Department of Energy

DOT U.S. Department of Transportation

DRI Desert Research Institute

EM Environmental Management

EML Environmental Management Laboratory

FY fiscal year

ICRP International Committee on Radiation Protection

LLW low-level radioactive waste

NCRP National Council on Radiation Protection and Measurements

NNSA/NSO National Nuclear Security Administration Nevada Site Office

nti no truck identified

NTS Nevada Test Site

PIC pressurized ion chamber

RCT radiological control technician

RS Reuter-Stokes

RWMC Radioactive Waste Management Complex

RWMS Radioactive Waste Management Site

US United States

WSIN Waste Shipment Identification Number 
THIS PAGE INTENTIONALLY LEFT BLANK 


\section{INTRODUCTION}

Since 1980, over $651,558 \mathrm{~m}^{3}\left(23,000,000 \mathrm{ft}^{3}\right)$ of low-level radioactive waste (LLW) have been disposed of at the Nevada Test Site (NTS) by shallow land burial. Since 1988, the majority of this waste has been generated at other United States (U.S.) Department of Energy (DOE) and Department of Defense (DoD) sites and facilities in the U.S. Between fiscal year (FY) 2002 and the publication date, the volumes of LLW being shipped by truck to the NTS increased sharply with the accelerated closure of DOE Environmental Management (EM) Program sites (DOE, 2002). The NTS is located $105 \mathrm{~km}(65 \mathrm{mi})$ northwest of Las Vegas, Nevada, in the U.S.

There continue to be public concerns over the safety of LLW shipments to the NTS. They can be broadly divided into two categories: (1) the risk of accidents involving trucks traveling on public highways; and (2) whether residents along transportation routes receive cumulative exposure from individual LLW shipments that pose a long-term health risk. The DOE and U.S. Department of Transportation (DOT) regulations ensure that radiation exposure from truck shipments to members of the public is negligible. Nevertheless, particularly in rural communities along transportation routes in Utah and Nevada, there is a perceived risk from members of the public about cumulative exposure, particularly when "Main Street" and the routes being used by LLW trucks are one in the same.

To provide an objective assessment of gamma radiation exposure to members of the public from LLW transport by truck, the Desert Research Institute (DRI) and the DOE, National Nuclear Security Administration Nevada Site Office (NNSA/NSO) established a stationary and automated array of four pressurized ion chambers (PICs) in a vehicle pullout for LLW trucks to pass through just outside the entrance to the NTS. The PICs were positioned at a distance of $1.0 \mathrm{~m}(3.3 \mathrm{ft})$ from the sides of the truck trailer and at a height of $1.5 \mathrm{~m}(5.0 \mathrm{ft}$ ) to simulate conditions that a member of the public (Turner, 1995) might experience if a truck were to pass while the person was on the side of the road, or if a truck were to come to a stop at a stoplight in one of the smaller towns along the transportation routes. The 1.0-m (3.3-ft) distance also allowed for comparison with gamma readings of trucks taken with portable, hand-held instruments at the two LLW disposal sites at the NTS: the Area 5 Radioactive Waste Management Complex (RWMC) and the Area 3 Radioactive Waste Management Site (RWMS). The purpose in automating the system was to provide the most objective and consistent measurement and calculation of radiation exposure from the trucks possible.

The array was set up in November 2002 and equipment was tested and calibrated over the next two months. Data collection on trucks began on February 13, 2003, and continued to the end of December 2003. In all, external gamma readings were collected from 1,012 of the 2,260 trucks that delivered LLW to the NTS during this period. Because DOE could not contractually require waste generators to participate in the study, the database is biased toward voluntary participants; however, data were collected from the 10 generators that represented 92 percent of the LLW shipments to the NTS during the study period, with another eight generators accounting for the balance of the shipments. Because of the voluntary nature of the participation, the identity of the waste generators is not used in the report. 
Previous studies on potential exposure to the public from transporting LLW to the NTS either relied on calculated exposures (Davis et al., 2002) or was based on a small population of trucks (e.g., 88) where a relatively high-background value of 50 microRoentgens per hour $(\mu \mathrm{R} / \mathrm{h})$ (background value measured at the LLW disposal sites) were subtracted from the gross reading of the truck trailer as measured by portable, handheld instruments (Gertz, 2001). The dataset that resulted from the DRI study is the largest collection of measurements of LLW trucks in transit of which the authors are aware.

\section{BACKGROUND}

\section{The Role of the NTS as a Regional LLW Disposal Site}

The NNSA/NSO EM Program supports the DOE complex by maintaining essential capability to dispose of LLW at the NTS from approved generators from across the DOE complex. This role was codified in the 1997 Waste Management Programmatic Environmental Impact Statement when the NTS was designated as one of two regional disposal sites for LLW. It is anticipated that the NTS will continue to be used by off-site generators until at least 2021 (DOE, 2002). Bechtel Nevada (BN) operates the two LLW disposal facilities at the NTS: the Area 5 RWMC and the Area 3 RWMS.

Presently, 29 DOE and DoD off-site generators from across the U.S. are approved for disposal of LLW at the NTS. This is in addition to disposal of LLW generated by NNSA/NSO's own EM activities, although this has amounted to less than one percent of the LLW disposed of in the last three years. With the DOE EM Program accelerating cleanup at several key sites between FY2002 and FY 2006, volumes of LLW being disposed at the NTS have substantially increased. In FY 2003, 91,777 $\mathrm{m}^{3}\left(3,239,720 \mathrm{ft}^{3}\right)$ of LLW was transported by truck from off-site generators to the NTS, the largest amount disposed of at the NTS in a single year. In addition, over 85,000 $\mathrm{m}^{3}\left(3,000,000 \mathrm{ft}^{3}\right)$ were disposed of in FY 2004.

\section{$\underline{\text { Standards and Dose Limits for LLW Truck Shipments }}$}

There are no gamma radiation exposure limits per se for LLW truck shipments. However, the DOT, in addition to regulating packaging, labeling, handling, marking, and placarding of trucks and train cars used for LLW shipments, also has shipping-standard dose rate limits for "closed," exclusive-use vehicles such as trucks being used for delivering LLW to the NTS (DOE, 1999). Standards include 2 millirems per hour $(\mathrm{mrem} / \mathrm{h})$ to the driver in the truck cab, $200 \mathrm{mrem} / \mathrm{h}$ at contact with the truck trailer, and $10 \mathrm{mrem} / \mathrm{h}$ at $2.0 \mathrm{~m}(6.6 \mathrm{ft})$ distance. For cumulative exposure and dose, applicable regulations and standards in the U.S. assume that the average person is exposed to a total effective dose equivalent of $360 \mathrm{mrem} / \mathrm{y}$ from all sources (NCRP, 1987). Also relevant are both 10CFR834, Subpart B, "Radiation Dose Limits for Members of the Public," and International Committee on Radiation Protection (ICRP) public dose limits. With the exception of radon (public exposure of which is regulated separately), ICRP and Subpart B limit exposure to members of the public from any licensed facilities (excluding medical) to $100 \mathrm{mrem} / \mathrm{y}$.

\section{Major Truck Routes and Travel Restrictions for LLW Trucks}

Six major trucking routes were used for transporting LLW through Nevada and western Utah to the NTS during the study period (Table 1 and Figure 1). As shown in Table 1, these six routes typically combine two or more of the DOE numbered routes, which 
are generally minor route variations or detours along major trucking routes, but also include interstate travel routes across the country. The six routes illustrated in Table 1 and Figure 1 are only those portions of the routes that pass through towns where a Community Environmental Monitoring Program (CEMP) station is located in Nevada. The towns of Delta and Cedar City, Utah, both along LLW transport routes to the NTS, also have CEMP stations.

The CEMP is a network of 26 stations, managed by DRI for the NNSA/NSO, located at ranches or in towns and cities around the NTS, used for monitoring of possible releases of radiation (Hartwell et al., 2001). Because the CEMP represents one of NNSA/NSO's major public outreach activities, particularly for rural communities near the NTS, DRI focused its cumulative exposure results on towns along transportation routes that host CEMP stations.

Table 1. Six major trucking routes used for transporting LLW to the NTS. Major towns along each route, including ones that host a CEMP station, are listed in parentheses.

\begin{tabular}{|c|c|c|c|}
\hline $\begin{array}{l}\text { Route } \\
\text { Number }\end{array}$ & Direction & Color & DOE Transportation Route Codes \\
\hline 1 & $\begin{array}{c}\text { South } \\
\text { (Shoshone, CA and Pahrump, NV } \\
{[\text { CEMP]) }}\end{array}$ & Yellow & $\begin{array}{l}\text { 01B, 01C, 01E, 02B, 02C, 02E, 02F, } \\
\text { 03B, 03C, 03D, 03E, 04B, 04C, 04D, } \\
\text { 05B, 05C, 05E, 06B, 06C, 06E, 10E }\end{array}$ \\
\hline 2 & $\begin{array}{c}\text { South } \\
\text { (Shoshone, CA and Amargosa Valley, NV } \\
{[\text { CEMP]) }}\end{array}$ & Green & $01 \mathrm{D}, 02 \mathrm{D}, 05 \mathrm{D}, 06 \mathrm{D}, 10 \mathrm{C}$ \\
\hline 3 & $\begin{array}{c}\text { North } \\
\text { (out of Cedar City, UT) } \\
\text { (Caliente, NV [CEMP]) }\end{array}$ & Orange & $12 \mathrm{~A}, 12 \mathrm{C}$ \\
\hline 4 & $\begin{array}{c}\text { North } \\
\text { (out of Reno, NV) } \\
\text { (Tonopah, NV [CEMP]) }\end{array}$ & Red & $11 \mathrm{~B}, 14 \mathrm{~A}, 14 \mathrm{~B}, 14 \mathrm{C}, 15 \mathrm{~A}, 16 \mathrm{~A}$ \\
\hline 5 & $\begin{array}{c}\text { North } \\
\text { (out of Delta, UT) } \\
\text { (Ely, NV [CEMP]) }\end{array}$ & Yellow & 09A \\
\hline 6 & $\begin{array}{c}\text { North } \\
\text { (out of Idaho or Salt Lake City, UT) } \\
\text { (Ely, NV [CEMP]) }\end{array}$ & Blue & $11 \mathrm{~A}, 17 \mathrm{~A}, 17 \mathrm{~B}$ \\
\hline
\end{tabular}

Along the six routes, LLW trucks travel through five Nevada towns with CEMP stations (Figure 1). Route 1 travels through Pahrump; Route 2 travels through Amargosa Valley; Route 3 travels through Caliente (these trucks also travel through Cedar City, Utah, and Rachel, Nevada); Route 4 travels through Tonopah (and subsequently through Goldfield, Sarcobatus Flat, and Beatty); Route 5 travels through Ely and then Tonopah (these trucks also travel through Delta, Utah); and Route 6 travels through Ely and then Tonopah (these trucks arrive at Ely from routes to the north that pass through Salt Lake City and West Wendover, Utah). However, as indicated on Figure 2, only trucks traveling on Routes 1, 2, 5, and 6 used the PIC array during the study period. In Figure 3, the number of trucks that were measured at the PIC array passing through particular towns with CEMP stations is shown. The Tonopah total is cumulative, and includes those trucks counted in both the Ely and 


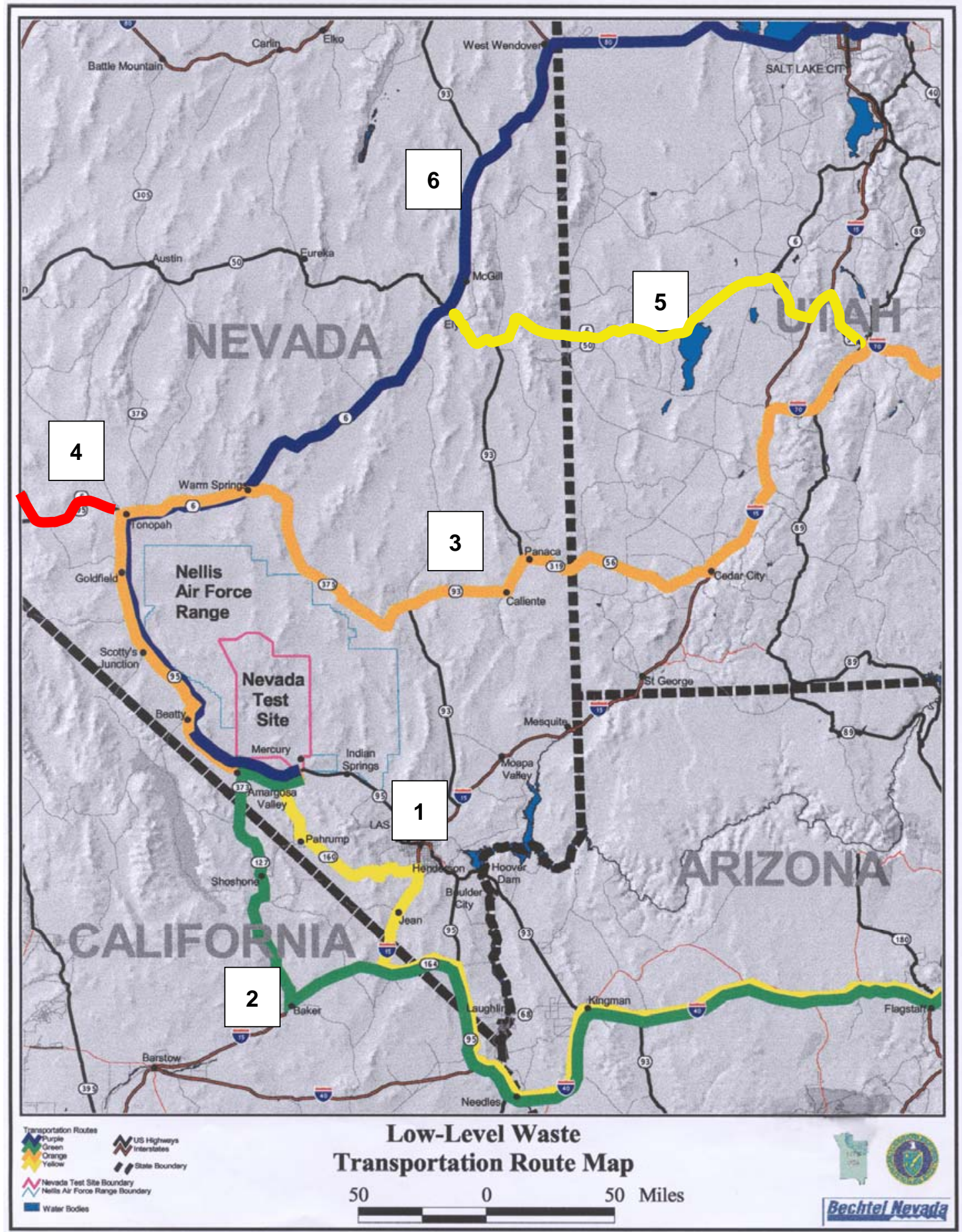

Figure 1. LLW transportation route map to the NTS. Las Vegas is located $105 \mathrm{~km}(65 \mathrm{mi})$ southeast of the entrance of the NTS near Mercury, where the PIC array was located. 


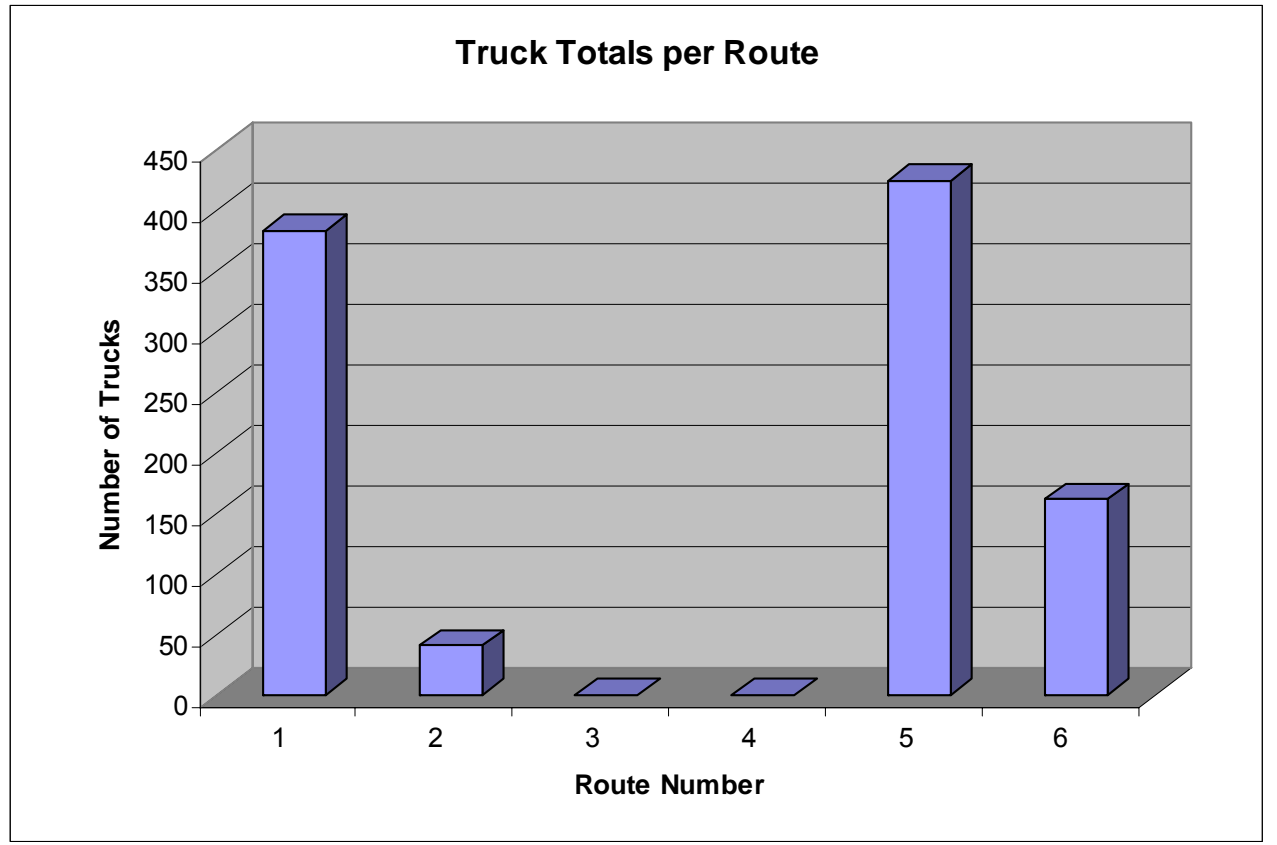

Figure 2. Bar graph of truck count per route.

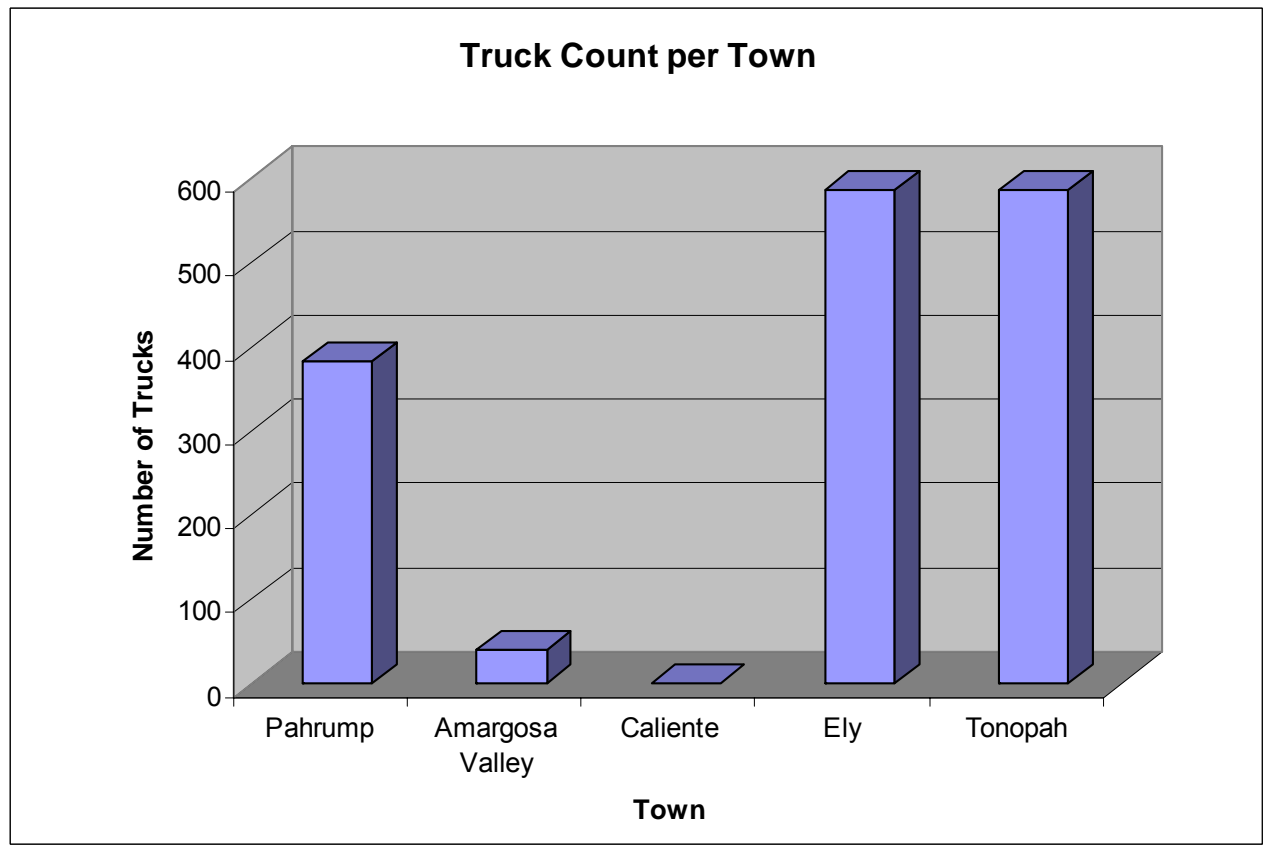

Figure 3. Bar graph of truck count per CEMP town. The Tonopah total includes those trucks counted in the Ely and Caliente totals, as well as trucks that intersect one of the major LLW transportation routes to the NTS at Tonopah. Gross counts for the routes were Pahrump (384 trucks), Amargosa Valley (42), Caliente (0), Ely (586), and Tonopah (586). Once a truck driver reached Ely, the only routes available to the NTS would take the truck through Tonopah as well. 
Caliente totals, as well as trucks solely traveling through Tonopah (Route 4) on their way to the NTS. However, as there were no trucks traveling on Routes 3 or 4, the totals for Ely and Tonopah are identical. Although the CEMP stations are equipped with PICs for measuring total gamma radiation, which are the same instruments used for measuring external exposure from LLW trucks at the PIC array, the CEMP stations are not positioned along highway routes to collect data specific to potential exposure from LLW truck transportation.

In the past, there were no travel restrictions on LLW truck transport to the NTS, either through the Las Vegas Valley or across Hoover Dam. Between FY 1997 and the third quarter of FY 1999, a total of 1,216 out-of-state shipments arrived at the NTS, with a total of 916, or 75 percent, of these trucks crossing into Nevada via Hoover Dam and 100 percent of the shipments traveling through the main highway interchange of US 95 and Interstate-15 (the "Spaghetti Bowl") in Las Vegas. However, former DOE Secretary Richardson made obligations to both the State of Nevada and the local governments within the Las Vegas Valley restricting these travel routes beginning in the fourth quarter of FY 1999. Trucks were no longer allowed to travel across the dam or through the valley, although a few drivers did still travel along these routes. During the fourth quarter of FY 1999 through FY 2001, only a few percent of the LLW trucks transporting to the NTS crossed Hoover Dam, and approximately 20 percent or less of the trucks traveled through the Spaghetti Bowl. After the events of September 11, 2001 (near the end of FY 2001), all truck travel across Hoover Dam was prohibited; thus, there have been no further LLW trucks crossing Hoover Dam. During this same time period, less than one percent of the LLW trucks have traveled through the Spaghetti Bowl or throughout the Las Vegas Valley along other routes.

\section{METHODS}

\section{PIC Array}

To measure exposure from LLW trucks, a stationary and automated array of four Reuter-Stokes (RS), Model RSS-131 High Pressure PICs was established at an existing roadside pullout along Mercury Highway just outside the main entrance to the NTS. The array was designed with two PICs on each side of the driveway, allowing a semi-truck to drive into the array and center the trailer between the two pairs of PICs (Figure 4, 5, and 6). As previously discussed, the PICs were positioned along the driveway so that they were $1.0 \mathrm{~m}(3.3 \mathrm{ft})$ away from the side of a standard truck trailer, at a height of $1.5 \mathrm{~m}(5.0 \mathrm{ft})$ to simulate the height of an adult citizen standing next to a LLW truck, and to be representative of the exposure of chest organs for a "Reference Man" using the Snyder-Fisher model of an adult human (Turner, 1995). The use of four PICs (two on each side) was to investigate for potential nonuniformity where gamma radiation levels from waste packages may vary from side to side, and from front to back in the truck trailer, depending upon packaging types and load arrangements. The PICs had a measurement range of approximately $2 \mu \mathrm{R} / \mathrm{h}$ to $800 \mu \mathrm{R} / \mathrm{h}$.

Photoacoustic sensors (Campbell Scientific SR50 instruments) were positioned on each side of the driveway between the PICs, horizontally aimed at the center of the driveway, and were used to detect when a truck entered and departed the array. Data from both the PICs and photoacoustic sensors were recorded on time-calibrated Campbell Scientific CR10X dataloggers, which were then manually downloaded to a laptop computer. A drivers' logbook was on-site for drivers to provide shipment identification information, and lights were 
provided at the PIC array so that it could be used 24 hours per day. Automating the array created an objective and consistent means to calculate the potential exposure from each truck.

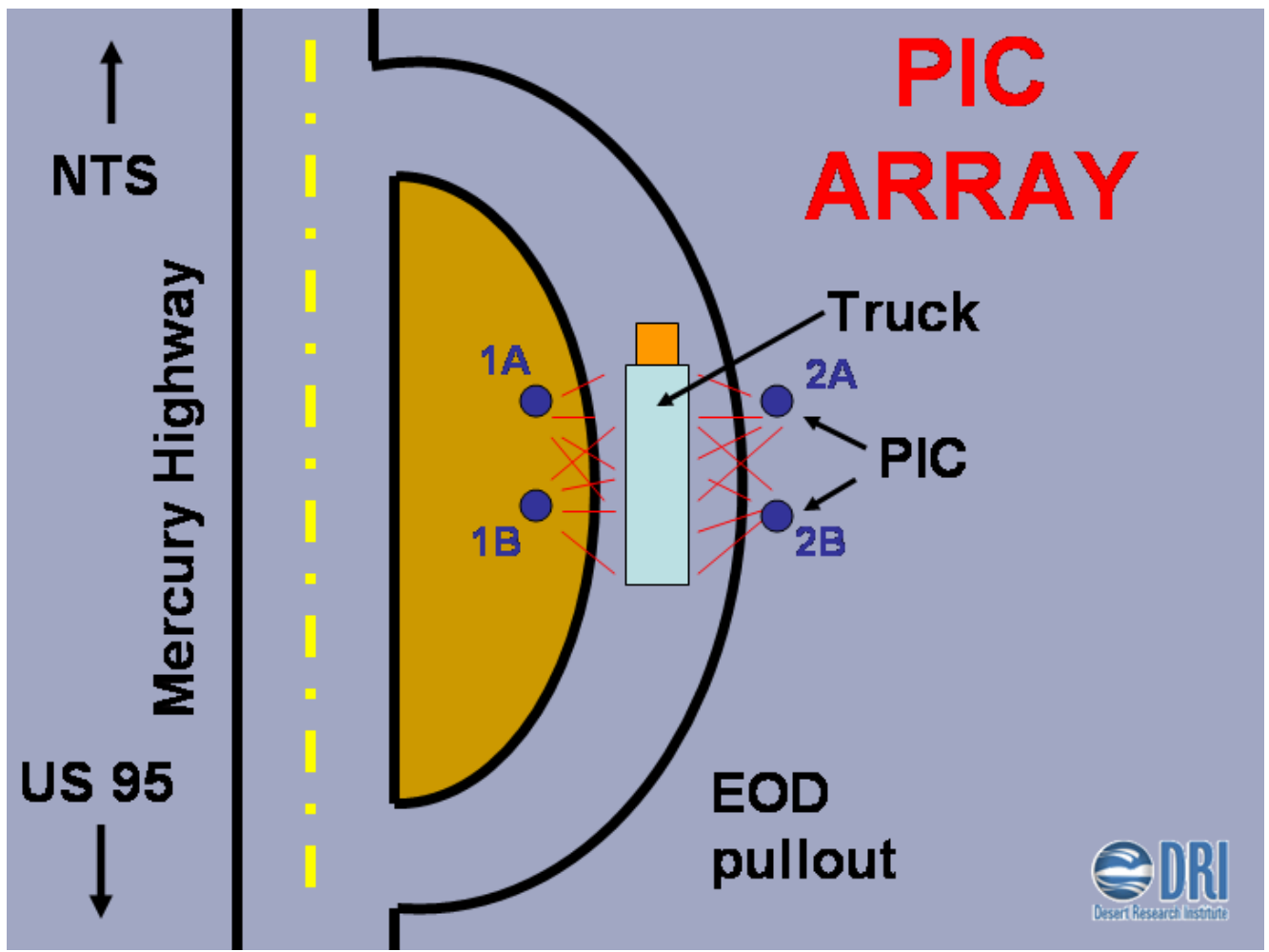

Figure 4. Plan view schematic of PIC array.

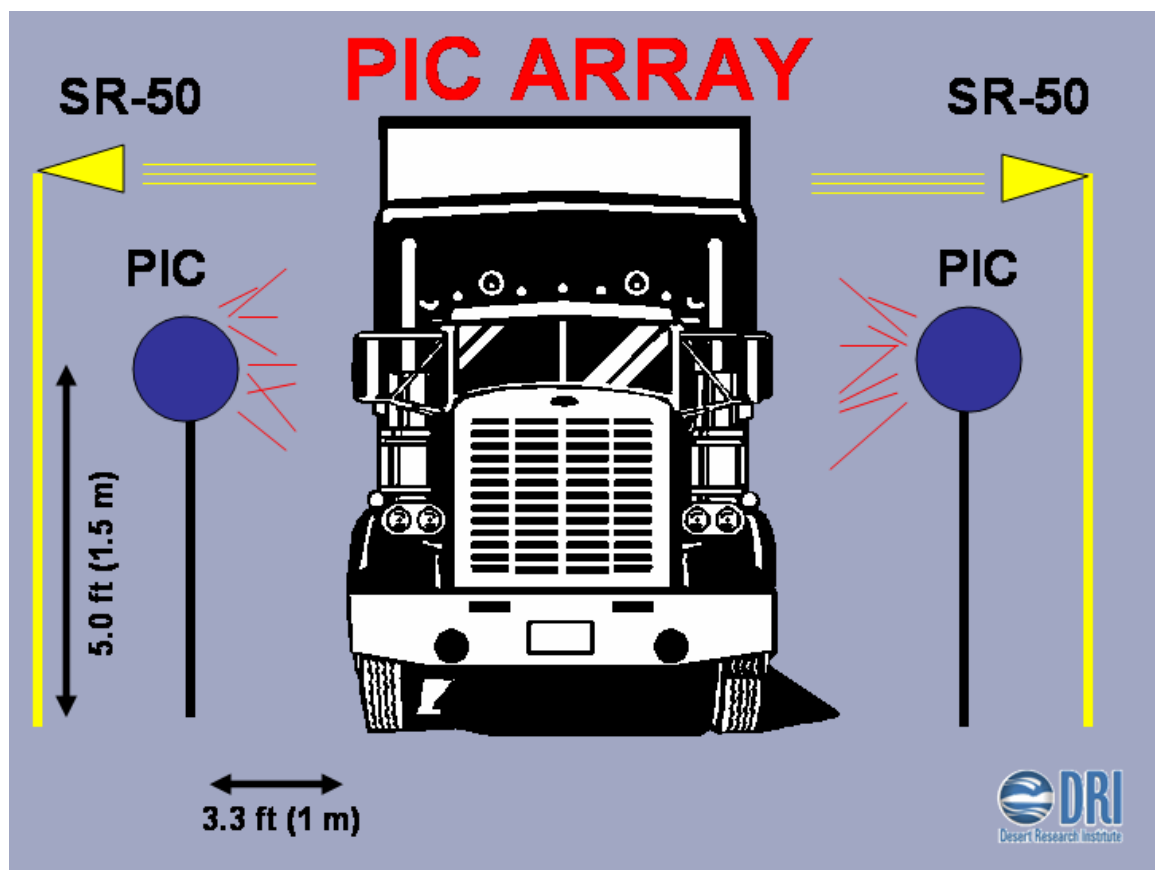

Figure 5. Front view schematic of PIC array. 


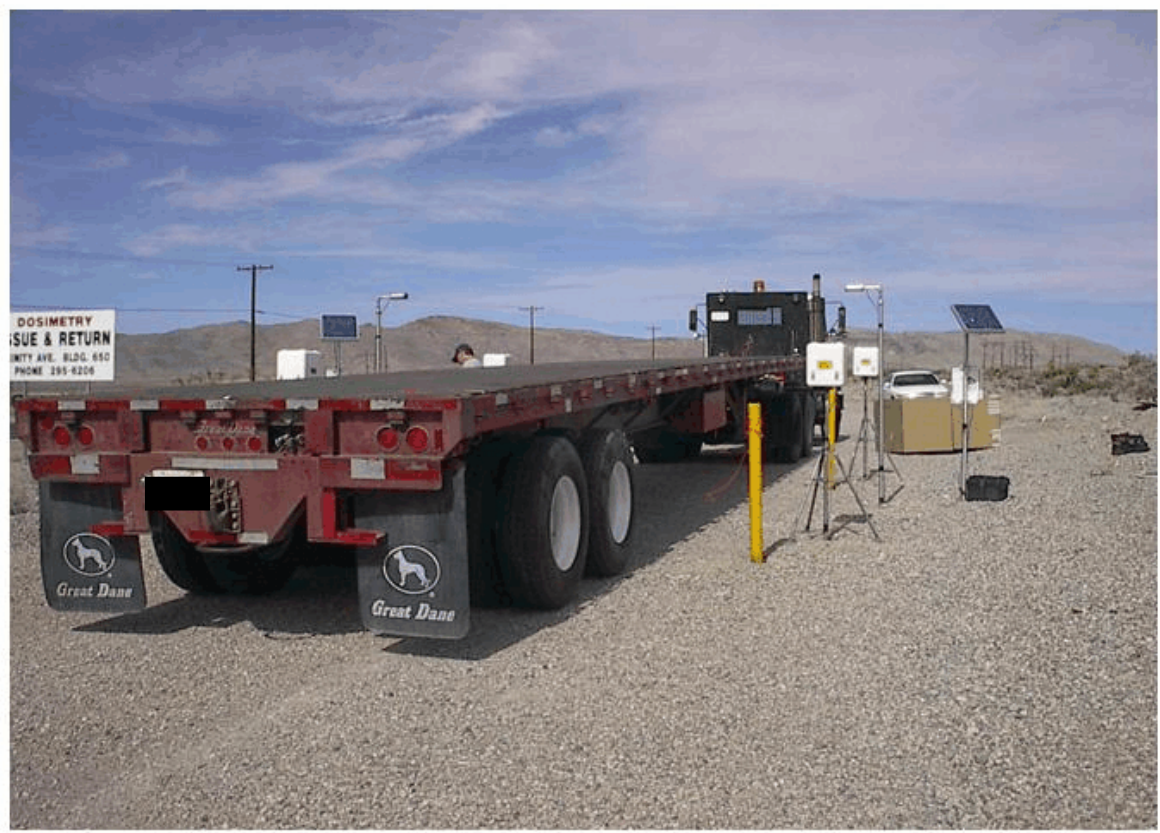

Figure 6. A flatbed truck in the PIC array during the setup of the instrumentation.

\section{Collecting and Processing Data from the PIC Array}

The dataloggers were programmed to continuously run, with PIC measurements collected at 5-sec intervals. The dataloggers were programmed to analyze these data at 2-min intervals, and record, for each 2-min interval, (1) the maximum 5-sec $\mu \mathrm{R} / \mathrm{h}$ value, (2) the minimum 5-sec $\mu \mathrm{R} / \mathrm{h}$ value, and (3) the average of all 5-sec PIC readings. The photoacoustic sensors detected when a truck passed through the PIC array during a 2-min interval. It was assumed that it would take the driver longer than two minutes to enter the required information into the array logbook; however, particularly when the minimum recorded PIC value was at background, there was evidence that the truck may not have remained within the array for the entire 2-min period. In these cases, the 2-min averaged PIC readings would incorporate both measurements from the truck as well as background readings before or after the truck was in the array. As a consequence, the maximum PIC values were determined to be the most consistent and reliable measurements of an actual truck. Thus, the highest maximum value from the four PICs during a 2-min interval was selected as the gross measurement for the truck.

\section{Collection of Background Data}

Readings taken when trucks were not present in the array were used to calculate two background values in a 24-h period: from $1946(7: 46 \mathrm{pm})$ to $0744 \mathrm{~h}(7: 44 \mathrm{am})$ and 0744 to $1946 \mathrm{~h}$. For consistency in using maximum exposure measurements from the trucks, the average of the maximum background values obtained during the specific 12-h window when a truck arrived at the PIC array, and the standard deviation of the background values, were subtracted from the gross reading of the truck to obtain net exposure values for each truck. 
Overall, background readings could vary from approximately 9 to $40 \mu \mathrm{R} / \mathrm{h}$, although typically background readings ranged between 10 and $15 \mu \mathrm{R} / \mathrm{h}$.

\section{Instructions to Generators}

To obtain the maximum population of radiological readings from trucks, the NNSA/NSO EM Program, in a letter to all approved offsite LLW generators, requested that all generator sites and their transportation companies participate in the study (DiSanza, 2002), assuming safe conditions for use of the PIC array site. For example, the pullout that was used was long enough that several trucks could be safely pulled off the highway at one time to wait their turn to go through the PIC array. However, the drivers were instructed to bypass the array if so many waiting trucks parked in the driveway created a backup along the driveway, causing drivers to stop their trucks along the shoulder of Mercury Highway. For safety reasons, the county sheriff would not allow trucks to be parked along the shoulder of the roadway leading to the main entrance gate at the NTS.

When a driver entered the array, he or she parked the truck trailer in a marked "footprint" within the array and then entered information into a logbook located at the site. The drivers were asked to record several key pieces of information about their waste shipment, including date and time of arrival, Waste Shipment Identification Number (WSIN) and final destination on the NTS (Area 3 RWMS or Area 5 RWMC, if known).

\section{Calibration of the PIC Array}

The objective in calibrating the PIC array was to examine the response of the PICs to a known source strength in the same array configuration used to study the potential radiation exposure of an LLW truck. The measurements could then be compared to the theoretical response versus distance (i.e., inverse-square law) curve and values calculated for the calibration source when the distance between the source and the PIC was increased. The PICs were permanently installed at the vehicle pullout area and positioned so that approximately one-third of the truck trailer extended beyond the front and back of the PIC array (Figure 3). An Isotope Products Laboratories $189.2 \mu \mathrm{Ci}$ source of ${ }^{137} \mathrm{Cs}$ (Nevada State Health Division, Radioactive Material License Number 16-13-0003-07) was mounted on a tripod within a Plexiglas ${ }^{\circledR}$ framework, selected to reduce or minimize absorption and scatter

of the ${ }^{137} \mathrm{Cs}$ gamma rays. A laser-light level was used to verify that the source was in the same horizontal and vertical planes as the center point of the PIC ionization chamber for each distance where PIC responses were measured.

The exposure rate was measured at three different distances between the source and the center of the PIC ionization chamber: $0.3 \mathrm{~m}(1.0 \mathrm{ft}), 0.5 \mathrm{~m}(1.6 \mathrm{ft})$, and $1.0 \mathrm{~m}(3.3 \mathrm{ft})$ (see Table 2). Gross or total gamma readings in $\mu \mathrm{R} / \mathrm{h}$ were taken every $5 \mathrm{sec}$ for a total of seven measurements at each distance. From the average value of the total gamma measurements, an average background reading (seven measurements total) was subtracted to yield a net value. The exposure and background rates, displayed on the screen of a connected laptop computer, were both hand recorded and digitally recorded on a connected datalogger, which was then downloaded to the laptop computer. Work was temporarily halted if winds at the site exceeded approximately 16 to $24 \mathrm{~km} / \mathrm{h}$ (10 to $15 \mathrm{mph})$. 
Table 2. Results of field calibration of the PICs in the array, as well as laboratory calibrations at DRI. Background readings were subtracted from gross readings of the PICs to obtain net readings in $\mu \mathrm{R} / \mathrm{h}$. Parenthetical values below the three distances from the source at which

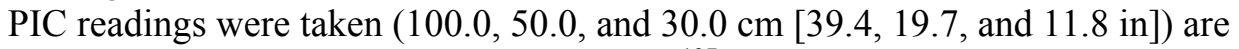
theoretical values for the source $\left(189.2 \mu \mathrm{Ci}{ }^{137} \mathrm{Cs}\right)$ used for calibration using the Inverse Square Law.

\begin{tabular}{|c|c|c|c|c|c|}
\hline \multicolumn{6}{|c|}{ Field Calibration } \\
\hline & & \multicolumn{3}{|c|}{ Net Readings $(\mu \mathrm{R} / \mathrm{h})$} & \multirow[b]{2}{*}{$\begin{array}{l}\text { Background } \\
\quad(\mu \mathrm{R} / \mathrm{h})\end{array}$} \\
\hline \multicolumn{2}{|c|}{$\begin{array}{c}\text { Distance } \\
\text { (Theoretical Value) }\end{array}$} & $\begin{array}{l}100 \mathrm{~cm} \\
(60.5)\end{array}$ & $\begin{array}{l}50 \mathrm{~cm} \\
(242.0)\end{array}$ & $\begin{array}{c}30 \mathrm{~cm} \\
(672.7)\end{array}$ & \\
\hline \multirow{2}{*}{ Datalogger 1} & PIC 1A & 62.7 & 243.0 & 672.0 & 11.7 \\
\hline & PIC 1B & 62.3 & 245.0 & 664.0 & 11.7 \\
\hline \multirow{2}{*}{ Datalogger 2} & PIC 2A & 57.4 & 225.0 & 614.0 & 11.1 \\
\hline & PIC 2B & 61.5 & 235.0 & 654.0 & 11.6 \\
\hline \multicolumn{6}{|c|}{ DRI Laboratory Calibration } \\
\hline \multirow{2}{*}{\multicolumn{2}{|c|}{$\begin{array}{c}\text { Distance } \\
\text { (Theoretical Value) }\end{array}$}} & \multicolumn{3}{|c|}{ Net Readings $(\mu \mathrm{R} / \mathrm{h})$} & \\
\hline & & $\begin{array}{l}100 \mathrm{~cm} \\
(60.5)\end{array}$ & $\begin{array}{l}50 \mathrm{~cm} \\
(242.0)\end{array}$ & $\begin{array}{c}30 \mathrm{~cm} \\
(672.7)\end{array}$ & $\begin{array}{l}\text { Background } \\
\quad(\mu \mathrm{R} / \mathrm{h})\end{array}$ \\
\hline \multirow{2}{*}{ Datalogger 1} & PIC 1A & 63.6 & 244.8 & 671.4 & 10.6 \\
\hline & PIC 1B & 63.8 & -- & -- & 10.9 \\
\hline \multirow{2}{*}{ Datalogger 2} & PIC 2A & 59.0 & 228.7 & 622.7 & 10.6 \\
\hline & PIC 2B & 61.9 & -- & -- & 10.3 \\
\hline
\end{tabular}

Following completion of the data collection phase in the field, the array was disassembled and the PICs brought back to the DRI laboratory in Las Vegas, Nevada. A similar calibration was performed on the PICs in the laboratory to compare against the measurements taken in the field. For PIC 1A and PIC 2A, a total of 15 measurements were taken in the laboratory at each of the same three distances measured in the field $(0.3 \mathrm{~m}$ $[1.0 \mathrm{ft}], 0.5 \mathrm{~m}[1.6 \mathrm{ft}]$, and $1.0 \mathrm{~m}[3.3 \mathrm{ft}])$ and net values calculated similar to the field calibration. Data were collected for PIC 1A for all three distances because they were also sent to the U.S. Department of Homeland Security's Environmental Measurement Laboratory (EML) for an independent cross-calibration check to verify quality assurance of the array. The measurements were performed in the laboratory for ease of comparison with the EML cross-calibration data. Exposure rate readings for PIC 2A were repeated at all three distances because PIC 2A showed a slight under-response to the source in the field. This underresponse was also measured in the laboratory. For PIC $1 \mathrm{~B}$ and PIC $2 \mathrm{~B}$, sets of measurements were taken only at a single distance of $1.0 \mathrm{~m}(3.3 \mathrm{ft})$ since these PICs were not being sent to EML for cross calibration. 
The following equations were used for calculating the measured exposure rate for each PIC and the theoretical or expected values versus distance using the Inverse Square Law for point sources of gamma radiation.

Exposure Rate (gamma ray point source):

$$
\mathrm{mR} / \mathrm{h}=\frac{n I_{y}}{d^{2}}
$$

where: $n=$ number of millicuries $(\mathrm{mCi})$

$I \gamma=\mathrm{mR} / \mathrm{h}$ at $1.0 \mathrm{~m}(3.3 \mathrm{ft})$ per $\mathrm{mCi}$ or 0.32 for ${ }^{137} \mathrm{Cs}$ NCRP, (NCRP, 1974)

$\mathrm{d}=$ distance $(\mathrm{m})$

Solving for $189.2 \mu \mathrm{Ci}$ or $0.1892 \mathrm{mCi}$ of ${ }^{137} \mathrm{Cs}$ (source):

$$
\mu \mathrm{R} / \mathrm{h}=\frac{[(0.1892)(0.32)]}{1 \mathrm{~m}^{2}}=60.5 \mu \mathrm{R} / \mathrm{hr}
$$

Equation for Inverse Square Law (for point sources of gamma radiation):

$$
\frac{I_{1}}{I_{2}}=\frac{\left(R_{2}\right)^{2}}{\left(R_{1}\right)^{2}} \text { or } I_{2}=I_{1} \times \frac{\left(R_{1}\right)^{2}}{\left(R_{2}\right)^{2}}
$$

where: $I_{1}=$ radiation intensity at distance $R_{1}$ from the source.

$I_{2}=$ radiation intensity at distance $R_{2}$ from the source.

In addition to the field calibration against a known source, direct measurements of the voltage supply using serial communication cables and software from RS was conducted.

There was only a 0.4 percent difference in the solid-state voltage outputs between the highest and lowest values for all four PICs (Table 3).

Table 3. Solid-state voltage outputs for the PICs.

\begin{tabular}{cc}
\hline PIC & Volts of direct current (vdc) \\
\hline PIC 1A & 399.6 \\
PIC 1B & 401.2 \\
PIC 2A & 400.4 \\
PIC 2B & 401.3 \\
\hline
\end{tabular}

As a final quality control check, PIC 1A was sent to the EML for an independent laboratory calibration. A 1-mg, National Institute of Standards and Technology-traceable ${ }^{266} \mathrm{Ra}$ needle source was used in a shadow field geometry at a distance between 4 and $5 \mathrm{~m}$ from the PIC. At this distance, the exposure rate for the direct beam ranged from 30 to $45 \mu \mathrm{R} / \mathrm{h}$. The result for the direct analog output from PIC $1 \mathrm{~A}$ was $14.1 \mathrm{mV}$ per $\mu \mathrm{R} / \mathrm{h}$. This calibration factor provided a room background reading of about $7 \mu \mathrm{R} / \mathrm{h}$. PIC $1 \mathrm{~A}$ was previously calibrated by RS in March 2001 with a ${ }^{137}$ Cs source and gave a value of 
$13.68 \mathrm{mV}$ per $\mu \mathrm{R} / \mathrm{h}$, a 3 percent difference from the EML reading, but well within the tolerance range for energy response variance for a PIC, particularly when different sources are used for calibration (Shebell, 2004).

\section{Data Collection, Management, and Analysis}

During the course of the data collection period, PIC and photoacoustic measurements were periodically downloaded via a laptop computer from the dataloggers at the PIC array into a Microsoft Excel spreadsheet. However, for the analysis of the data for potential exposure values, a Microsoft Access database was developed. A sample of the database for a truck with PIC-detected, above-background exposure readings is shown in Table 4. As discussed previously, the dataloggers ran continuously and export of the gamma readings were recorded in military time. The conversion to Julian time was made in the Microsoft Access database. Plotting of gamma readings as a function of time graphically was another means of identifying a truck in the PIC array (Figure 7).

Table 4. Sample Microsoft Access database format for LLW truck transportation exposure data collected on dataloggers at the PIC array. The data are for PIC 1A when a LLW shipment went through the array. The shipment identification number was recorded by the driver in the logbook, although the actual number shown in this table is fictitious. The approximately 2-min period when the truck was detectable in the PIC array is highlighted in gray. The maximum PIC readings in $\mu \mathrm{R} / \mathrm{h}$ of 47.87 and 59.35 are in excess of PIC readings preceding and following the truck, which represent background readings. Days are in Julian Days starting in January 2003. Time is recorded in military time. In this case, the truck went through the PIC array between 12 noon and 12:30 P.M. on March 2, 2003.

\begin{tabular}{|c|c|c|c|c|c|c|c|c|c|}
\hline $\begin{array}{l}\text { Shipment } \\
\text { ID }\end{array}$ & $\begin{array}{l}\text { Validated } \\
\text { ID }\end{array}$ & Notes & J-Day & Time & $\begin{array}{c}\text { PICA } \\
\text { Avg } \\
\mu \mathrm{R} / \mathrm{hr}\end{array}$ & $\begin{array}{l}\text { PICA } \\
\text { Min } \\
\mu \mathrm{R} / \mathrm{hr}\end{array}$ & $\begin{array}{l}\text { PICA } \\
\text { Min } \\
\text { Time }\end{array}$ & $\begin{array}{l}\text { PICA } \\
\text { Max } \\
\mu \mathrm{R} / \mathrm{hr}\end{array}$ & $\begin{array}{c}\text { PICA } \\
\text { Max } \\
\text { Time }\end{array}$ \\
\hline & & & 61 & 1210 & 11.33 & 9.53 & 1208 & 14.17 & 1209 \\
\hline & & & 61 & 1212 & 11.16 & 9.77 & 1210 & 12.70 & 1211 \\
\hline & & & 61 & 1214 & 11.36 & 9.28 & 1212 & 15.63 & 1213 \\
\hline & & & 61 & 1216 & 10.91 & 10.01 & 1214 & 12.70 & 1215 \\
\hline \multirow[t]{6}{*}{ NTS12345 } & NTS12345 & $\mathrm{OK}$ & 61 & 1218 & 33.96 & 9.77 & 1216 & 47.87 & 1217 \\
\hline & & & 61 & 1220 & 42.85 & 11.23 & 1220 & 59.35 & 1219 \\
\hline & & & 61 & 1222 & 11.40 & 10.26 & 1221 & 12.94 & 1220 \\
\hline & & & 61 & 1224 & 11.19 & 9.53 & 1222 & 12.94 & 1222 \\
\hline & & & 61 & 1226 & 11.18 & 9.53 & 1225 & 13.68 & 1225 \\
\hline & & & 61 & 1228 & 11.37 & 10.01 & 1227 & 12.70 & 1227 \\
\hline
\end{tabular}




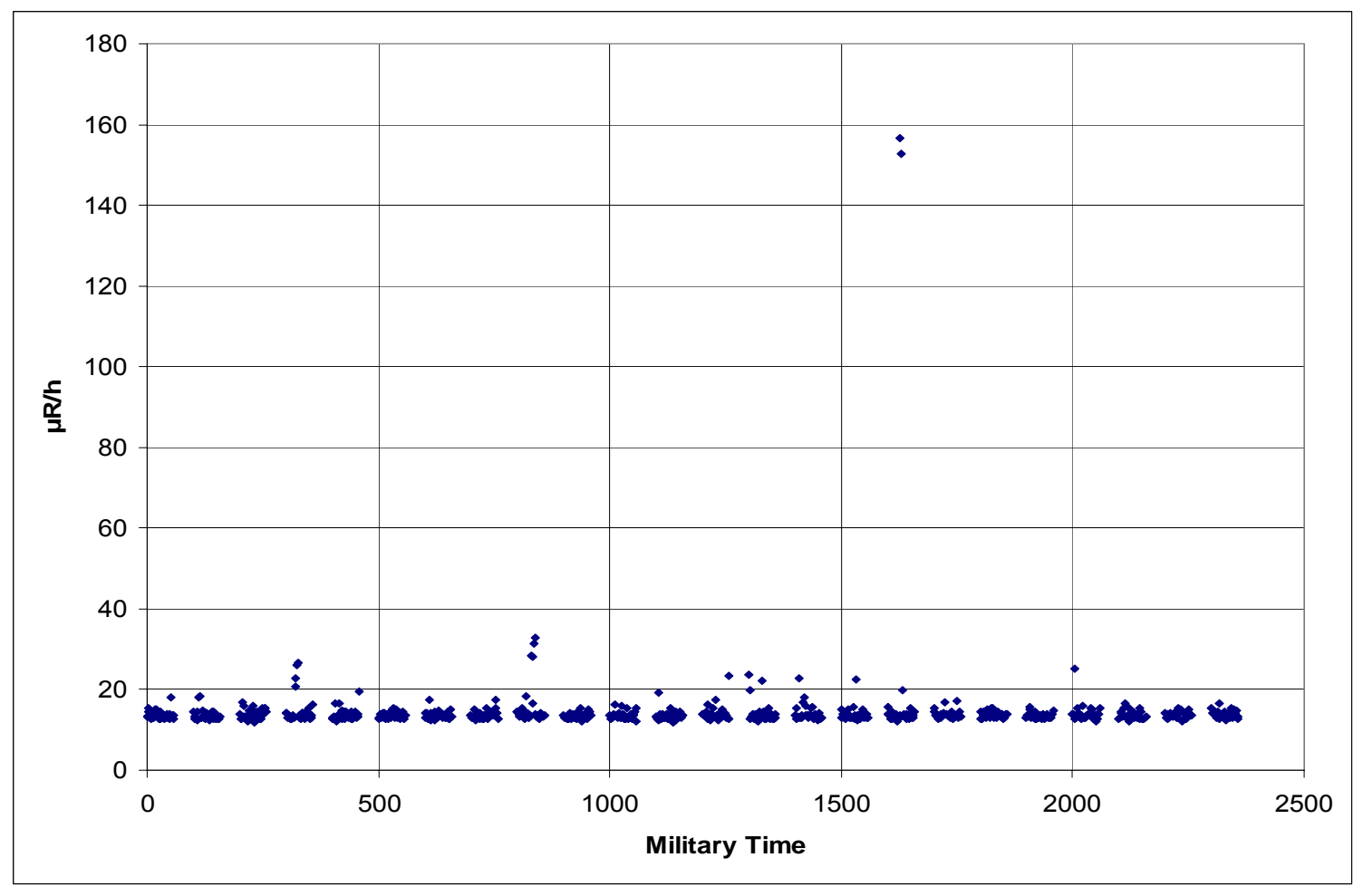

Figure 7. Maximum readings from PIC 2B on May 5, 2003, plotted as a function of military time. Readings between approximately 10 and $35 \mu \mathrm{R} / \mathrm{h}$ represent readings of maximum background during 2-min intervals. Two higher readings between approximately 150 and $160 \mu \mathrm{R} / \mathrm{h}$ at about $1600 \mathrm{~h}$ is a truck in the PIC array.

The most significant information provided by the drivers in the logbook was the WSIN, which allowed PIC readings from the truck to be compared to information on the waste manifest sheets collected at the Area 5 RWMC and Area 3 RWMS. Thus, having the WSIN for each truck facilitated comparison of truck readings collected at the PICs to waste type and inventory, generator, radiation readings collected at the Area $5 \mathrm{RWMC}$ and Area 3 RWMS, and transportation route information.

\section{Criteria for Identifying a Truck in the PIC Array}

The LLW transportation database was date/time justified for those instruments tied to dataloggers including the PICs and the photoacoustic sensors. Ideally, a truck could be added to the database because the following events were observed or recorded:

- The SR50 and SR50 Q data indicated the presence of an "object" (presumably a truck based upon sensor height) between 1.5 and $1.9 \mathrm{~m}$ (4.9 and $6.2 \mathrm{ft})$ distance from the sensors.

- The truck driver recorded his or her arrival in the logbook at a time consistent with the SR50 and SR50 Q recorded time.

- The WSIN was also recorded in the logbook. 
- Finally, for the trucks with a gross exposure measurement above background, one or more of the PICs recorded a gamma reading that was higher than preceding PIC measurements, which would represent background readings. However, especially for trucks with an external exposure at or only slightly above background, PIC readings alone, with no other supporting data, were insufficient evidence of a truck.

Some of the data recorded by the truck drivers, however, were incorrect or incomplete. Common problems encountered, but that could be corrected, included the following:

1. The driver recorded the wrong date.

2. The driver recorded the wrong time, or the time that was recorded was correct for the time zone where he or she began her trip to the NTS. In some cases, no time of arrival at the PIC array was recorded, although information on the truck was otherwise written down.

3. The origin of the waste was not recorded, or the wrong code was used for the site of origin.

A correctly recorded WSIN was the most valuable quality assurance data for correcting the database. When errors or omissions were made by the drivers in the logbook, the WSIN was compared with the waste manifest records maintained at the Area 5 RWMC, which previously had been copied and collected for comparison with the PIC database, and were used to ascertain the correct information. The waste manifests also served as a secondary check of a truck that was measured as "above background" in terms of the gamma radiation field at the PIC array because they frequently were recorded as "above background" at the Area 5 RWMC or Area 3 RWMS based on near-contact gamma radiation measurements made with portable, hand-held instruments. Finally, because the datalogger provided a continuous record of the PICs and the photoacoustic sensors, a truck whose arrival time was incorrectly recorded was still represented within the database as the next truck that used the PIC array. Thus, simply knowing the sequence of trucks that used the array was sometimes enough to correct the database. In the case of the wrong generator code being logged in, if the remainder of the WSIN was correctly recorded, then the site generator code could be corrected.

An unanticipated situation was trucks traveling in a convoy and going through the PIC array as a group with virtually no break in time between each truck. This typically occurred in the morning before the entrance to the NTS was opened. As an example, four truck drivers signed the logbook as the first truck sat in the array, and then all drove their vehicles straight through without stopping, rather than each driver individually parking the truck in the array while he or she recorded information in the logbook. The convoy situation created data records where the response time of the instruments was not fast enough to distinguish each vehicle. In such cases, the numbers of unique readings that could be identified were recorded for an appropriate number of trucks, but the remainder were also recorded as "nti" (no truck identified). An overall assumption was that only LLW trucks were driven through the PIC array.

Nevertheless, as previously mentioned, there is a subpopulation of measurements that may represent trucks passing through the PIC array. The best evidence of this was a 
combination of photoacoustic sensors recording the presence of an object and, in some of these same cases, one or more of the PICs recorded readings clearly exceeding the background readings preceding the event. In these cases, an nti was recorded, and the date and time were noted in the database. Because there were episodes of increased gamma radiation readings unrelated to a truck, simply having an episode of higher gamma readings was insufficient evidence of a LLW truck. The nti records were retained in a separate database. However, they were not included among the 1,012 trucks in the database and their apparent net exposure values were not used to calculate background nor the standard deviation for the 12-h periods when recorded trucks used the PIC array. In addition, PIC readings during periods when the array was calibrated were removed when background values were calculated.

\section{Truck Exposure Readings Greater than $800 \mu \mathrm{R} / \mathrm{h}$}

A problem not discovered until after data collection was well underway, was the performance of the PICs for trucks with gross exposure readings exceeding $800 \mu \mathrm{R} / \mathrm{h}$. Although manufacturer specifications for the Reuter-Stokes, Model RSS-131, PIC used in this study stated that the instrument would read to $1,000 \mu \mathrm{R} / \mathrm{h}$, it was subsequently found that a second channel on the PIC had to be used for measurements over $800 \mu \mathrm{R} / \mathrm{h}$, and even then, pursuant to the manufacturer, the "analog sensitivity output is invalid" for measurements between 800 and 1,000 $\mu \mathrm{R} / \mathrm{h}$ (Reuter-Stokes, 2001). Of the 1,012 trucks measured, 59 had gross gamma readings at the PIC array greater than $800 \mu \mathrm{R} / \mathrm{h}$.

To rectify this situation, when a record of $800 \mu \mathrm{R} / \mathrm{h}$ or greater occurred, the WSIN from the truckers' logbook was used to find the specific waste manifest sheet from the RWMC or RWMS records. As previously discussed, the waste manifest sheets include the hand-held radiation instrument readings made by the LLW radiological control technicians (RCT) at the RWMC and RWMS. The RCTs routinely record onto the waste manifest sheets the gamma radiation measurements of the highest readings at the surface of the truck trailer, at $0.3 \mathrm{~m}(1.0 \mathrm{ft})$ distance from the trailer, at $1.0 \mathrm{~m}(3.3 \mathrm{ft})$ distance from the trailer, and at the truck cab, approximately $3 \mathrm{~m}(10 \mathrm{ft})$ distance from the trailer. The radiation readings are made using a Ludlum Model 3, hand-held gamma detector. In all, data from 77 trucks, including the 59 recorded at the PIC array, with gross measurements greater than $800 \mu \mathrm{R} / \mathrm{h}$, were examined to evaluate whether the $1.0 \mathrm{~m}(3.3 \mathrm{ft})$ measurements at the Area $3 \mathrm{RWMS}$ and the Area $5 \mathrm{RWMC}$ could be substituted for the greater than $800 \mu \mathrm{R} / \mathrm{h}$ at the PIC array.

One concern was whether the measurements of individual trucks at the RWMC were unduly influenced by neighboring trucks, thereby artificially increasing the gross gamma measurements made by the RCTs. In examining the radiation readings for each of the trucks at the cab, a distance of $3 \mathrm{~m}(10.0 \mathrm{ft})$ from the truck trailer, 73 of the 77 trucks ( 94.8 percent) had readings indistinguishable from background, typically $50 \mu \mathrm{R} / \mathrm{h}$ at the disposal site (Gertz, 2001). Four trucks had measurements above the disposal site background value at the cab. However, these four trucks also had the highest "on contact" readings of the population of 77 trucks, and as expected, had the highest readings at the cab. However, the preponderance of cab readings for the 77 trucks that were below background suggests that the hand-held readings were not artificially increased by adjacent trucks. Also, as the waste inventories of each shipment were already known at the disposal site prior to the truck's arrival, any truck that would have radiation readings above background was immediately 
segregated from the other trucks, and parked in an isolated part of the parking lot. Another check of consistency between measurements taken at the PIC array and measurements taken at the RWMC was that, in all but one case, trucks measured at the PIC array that produced gross exposure values exceeding $800 \mu \mathrm{R} / \mathrm{h}$ also produced values at the RWMC that exceeded $800 \mu \mathrm{R} / \mathrm{h}$ at a distance of $1.0 \mathrm{~m}(3.3 \mathrm{ft})$. In the one exception, the $\mathrm{RWMC}$ reading was $750 \mu \mathrm{R} / \mathrm{hr}$.

However, before using the 1.0-m (3.3-ft) readings made by the RCTs in place of the greater than $800 \mu \mathrm{R} / \mathrm{h}$ reading at the PIC array, the collective relationship of the truck readings to one another was examined to establish whether the readings made with the handheld instruments could be used to predict exposure readings comparable to the readings made at the PIC array. To investigate this, each truck's hand-held readings at $0.3 \mathrm{~m}(1.0 \mathrm{ft})$ and $1.0 \mathrm{~m}(3.3 \mathrm{ft})$ were normalized to their own surface contact readings. The distances were first corrected for the typical thickness of the sidewall of a van-type truck trailer, $0.022 \mathrm{~m}$ $(0.07 \mathrm{ft})$. As such, the Ludlum Model 3 readings were plotted such that the contact reading was $0.022 \mathrm{~m}(0.072 \mathrm{ft})$, and subsequent readings at increasing distances were corrected to $0.322 \mathrm{~m}$ and $1.022 \mathrm{~m}(1.07$ and $3.35 \mathrm{ft})$. The data were then evaluated to see if the slope of the resulting curve (gross gamma reading versus distance) and its standard deviation would suggest that the data behaved in a manner such that readings at $1.0 \mathrm{~m}(3.3 \mathrm{ft})$ were predictable.

Figure 8a illustrates the slope of the average ratio. The trend line was derived with a least-square fit using the following equation: $\mathrm{y}=\mathrm{cx}$ where $c$ and $b$ are constants. The standard deviation for the $0.322-\mathrm{m}(1.07-\mathrm{ft})$ point is \pm 17 percent, while the $1.022-\mathrm{m}(3.35-\mathrm{ft})$ point is \pm 35 percent. The slope of the line ranged from -0.17 to -0.35 , with a value of -0.24 for the mean. Measurements made with the hand-held instruments at the Area $5 \mathrm{RWMC}$ at $1.0 \mathrm{~m}$ $(3.3 \mathrm{ft})$ were \pm 35 percent. It was the judgment of the authors that the 35 percent standard deviation of the 1.0-m (3.3-ft) measurements at the RWMC did not preclude the RWMC data from being used in the transportation exposure database for the trucks whose gross reading exceeded $800 \mu \mathrm{R} / \mathrm{h}$ at the PIC array. There were five trucks at the PIC array for which at least one PIC measurement exceeded $800 \mu \mathrm{R} / \mathrm{h}$, but for which survey information from the RWMC on the NTS could not be obtained. However, as these trucks were all from the same generator, the average normalized gross exposure from other trucks of this generator with PIC measurements exceeding $800 \mu \mathrm{R} / \mathrm{h}$ was used for these trucks.

\section{Reduction in Radiation Intensity as a Function of Distance from LLW Trucks}

Another benefit of examining the Ludlum Model 3 readings collected at the Area 5 RWMC was to examine the rate at which radiation intensity readings decreased as a function of increasing distance away from the 77 trucks examined with readings exceeding $800 \mu \mathrm{R} / \mathrm{h}$. In previous studies of LLW truck transportation to the NTS, trucks have been treated both as a point source (Gertz, 2001) and as a line source (Davis et al., 2002). However, as illustrated in a comparison of Figures 8a, 8b, and 8c, the rate of decrease with distance may be much lower or "slower" than would be predicted by assuming either a point or a line source. 

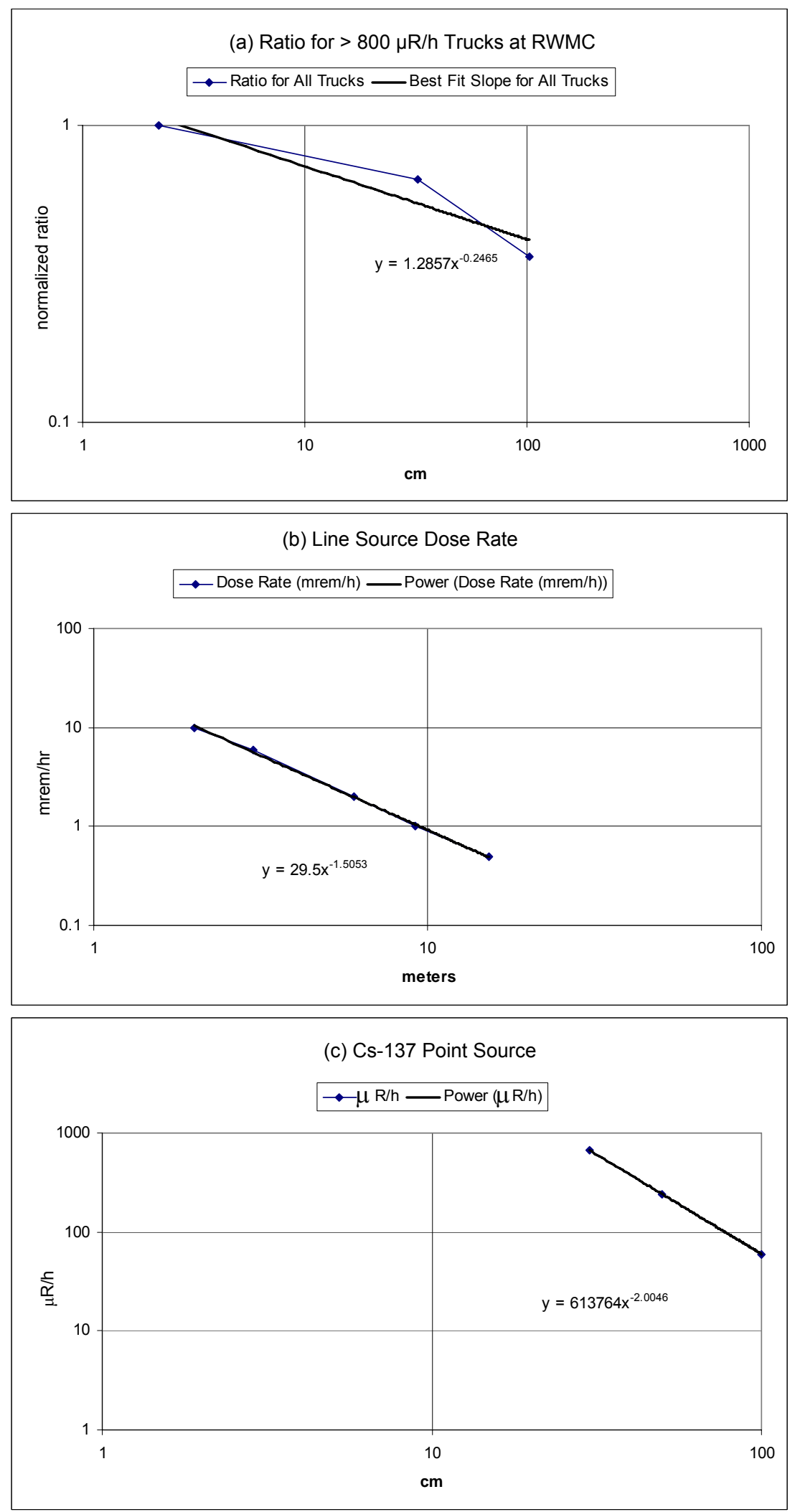

Figure 8. Rates of radiation intensity reduction as a function of increasing distance. 
In Figure 8a, the slope is based on the normalized ratios of gross gamma readings at $0.022,0.322$, and $1.022 \mathrm{~m}(0.07,1.07$, and $3.35 \mathrm{ft})$ for the 77 trucks with readings exceeding $800 \mu \mathrm{R} / \mathrm{h}$. In Figure $8 \mathrm{~b}$, for a line source, the following equation would be used to calculate the slope: $\mathrm{m}=\log \left(\mathrm{y}_{2} / \mathrm{y}_{1}\right) / \log \left(\mathrm{x}_{2} / \mathrm{x}_{1}\right)$. Data are from Davis et al. (2002). In Figure $8 \mathrm{c}$, data from Shebell (2004) are used to calculate the slope, "m", for a point source in log-log space, using the power function equation of $y=a / x^{m}$. The slopes of the resulting curves indicate significant differences. For the 77 trucks examined from the RWMC, the average slope is -0.24 (Figure $8 \mathrm{a}$ ). For the line source, the slope is -1.5 (Figure $8 \mathrm{~b}$ ), while for the point source, the slope of the curve is -2.0 (Figure $8 \mathrm{c}$ ). For example, if the three equations (normalized, line source, and point source) were used to predict the radiation exposure values at $2.0 \mathrm{~m}$ $(6.6 \mathrm{ft})$ when the exposure value is known to be $10 \mathrm{mR} / \mathrm{h}$ at $1.0 \mathrm{~m}(3.3 \mathrm{ft})$, the resulting values would be $7.5,3.5$, and $2.5 \mathrm{mR} / \mathrm{h}$, respectively. In summary, the slope from the observed, normalized truck value ratios at the Area 5 RWMC was considerably slower than if the same trucks were treated as line or point sources.

There may be good reasons why the LLW trucks examined are not behaving similar to point or line sources. The LLW shipments to the NTS are configured with packages that are most likely randomly arranged within the trailer with regard to heterogeneity of waste forms and radioactive content, as well as total radioactivity of containers. In fact, it was for this reason that the PIC array was designed with four PICs rather than relying on a single PIC measurement. The authors could find no references describing the observed phenomena for LLW shipments. Further examination of this issue is discussed in the recommendations section of this report.

\section{Calculation of Net Exposures for a Truck}

As discussed previously, background radiation measurements were continually measured by the PICs when trucks were not parked within the array. For each 2-min period, the datalogger recorded the maximum reading from each PIC, the average value, and minimum value. An "average" background for a given period of time (e.g., $12 \mathrm{~h}$ ) was calculated by taking the average of the 2-min averages for that period. Thus, two daily 12-h time periods were selected to determine background values, representing "daytime" (0746 to

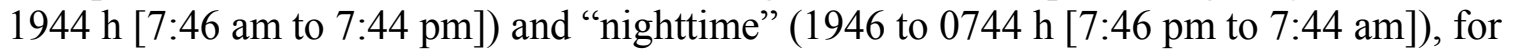
any diurnal changes in background values. For each 12-h time frame, the average readings from the PICs were totaled, divided by the total number of readings (usually 360 readings for each $12 \mathrm{~h}$ ), and an average background value for that specific $12-\mathrm{h}$ period was determined. If within any 12-h period LLW trucks were responsible for any of the 2-min values, the database queries for background were modified to reject those specific records so they did not contribute to the total background readings for the 12-h period. Thus, if a single truck was in the array during a specific 12-h period, and the database records showed that it was there for one PIC reading cycle, then that average PIC reading record was not included in the total of all average PIC readings, and the total number of readings was reduced to 359 . Thus, the waste inventory within that truck was not allowed to skew the calculated background readings. Last, for each $12-\mathrm{h}$ period, a standard deviation of the average background readings was calculated.

To avoid any perception of biasing a potential exposure low, the maximum PIC reading from the array (i.e., the single highest reading of the four PICs) for each truck measurement was assigned as the maximum gross radiation value for each truck. To calculate 
the "net exposure" for each truck, the average of the maximum background values during the corresponding 12-h period when the truck arrived at the PIC array, as well as the absolute value of the standard deviation of the background reading, was subtracted from the maximum gross exposure measurement of the truck recorded (see Appendix). If, after subtracting the background and standard deviation from the gross radiation exposure value of the truck, the net exposure was equal to or less than zero, then the truck was considered as having no potential exposure above background, and was assigned a net exposure value of "zero." For the 59 trucks whose gross exposure measurements exceed $800 \mu \mathrm{R} / \mathrm{h}$, the background and standard deviation for when the truck went through the PIC array was used instead of the standard $50-\mu \mathrm{R} / \mathrm{h}$ background with no standard deviation that is used at the Area $5 \mathrm{RWMC}$.

In calculating background, values from three of the four PICs were used. The exception was PIC 1B, as there were episodes during the study period when transmission from this PIC was interrupted. Because there was some uncertainty about the duration of these events, its background readings were not incorporated with those of the other PICs.

Table 5. The net exposure results for a subset of trucks that passed through the PIC array between July 1 and July 8, 2003. For these net exposure calculations, the average of the 2-min PIC array maximum background measurements, and its standard deviation, taken during the 12-h period during which each truck arrived, was subtracted from the gross value measured when the truck was within the array. A net exposure value of zero or less than zero was assigned as "zero." The "Sequence Number" is only for ease in using this table and does not correspond to the Sequence Number for the entire truck data set in Appendix. See Figure 1 for route numbers.

\begin{tabular}{|c|c|c|c|c|c|c|c|}
\hline $\begin{array}{l}\text { Sequence } \\
\text { Number }\end{array}$ & Date & $\begin{array}{l}\text { Time of } \\
\text { Shipment }\end{array}$ & $\begin{array}{l}\text { Gross } \\
\text { Value }\end{array}$ & $\begin{array}{l}\text { Maximum } \\
\text { Background }\end{array}$ & $\begin{array}{l}\text { Standard } \\
\text { Deviation }\end{array}$ & $\begin{array}{c}\text { Net } \\
\text { Exposure }\end{array}$ & $\begin{array}{c}\text { Route } \\
\text { Number }\end{array}$ \\
\hline 1 & July 1, 2003 & 10:20:00 PM & 15.08 & 13.76 & 1.43 & -0.12 & 1 \\
\hline 2 & July 2, 2003 & 1:20:00 AM & 15.08 & 13.76 & 1.43 & -0.12 & 1 \\
\hline 3 & July 2, 2003 & 4:20:00 AM & 15.09 & 13.76 & 1.43 & -0.11 & 5 \\
\hline 4 & July 2, 2003 & 6:00:00 AM & 14.85 & 13.76 & 1.43 & -0.35 & 5 \\
\hline 5 & July 2, 2003 & 6:04:00 AM & 14.85 & 13.76 & 1.43 & -0.35 & 5 \\
\hline 6 & July 2, 2003 & 6:06:00 AM & 15.63 & 13.76 & 1.43 & 0.43 & 5 \\
\hline 7 & July 6, 2003 & $8: 26: 00$ PM & 15.37 & 13.94 & 1.23 & 0.21 & 1 \\
\hline 8 & July 6, 2003 & 11:32:00 PM & 15.08 & 13.94 & 1.23 & -0.08 & 2 \\
\hline 9 & July 6, 2003 & 11:34:00 PM & 16.56 & 13.94 & 1.23 & 1.40 & 1 \\
\hline 10 & July 6, 2003 & 11:36:00 PM & 15.32 & 13.94 & 1.23 & 0.16 & 1 \\
\hline 11 & July 7, 2003 & 12:18:00 AM & 14.84 & 13.94 & 1.23 & -0.32 & 1 \\
\hline 12 & July 7, 2003 & $12: 20: 00 \mathrm{AM}$ & 15.08 & 13.94 & 1.23 & -0.08 & 1 \\
\hline 13 & July 7, 2003 & 7:00:00 AM & 17.33 & 13.94 & 1.23 & 2.17 & 5 \\
\hline 14 & July 7, 2003 & 5:34:00 PM & 14.64 & 13.98 & 1.37 & -0.71 & 5 \\
\hline 15 & July 7, 2003 & 8:06:00 PM & 15.51 & 13.82 & 1.16 & 0.53 & 5 \\
\hline 16 & July 7, 2003 & 9:30:00 PM & 15.56 & 13.82 & 1.16 & 0.58 & 5 \\
\hline 17 & July 8, 2003 & 12:30:00 AM & 15.32 & 13.82 & 1.16 & 0.34 & 1 \\
\hline 18 & July 8, 2003 & $12: 32: 00 \mathrm{AM}$ & 15.08 & 13.82 & 1.16 & 0.10 & 1 \\
\hline 19 & July 8, 2003 & 5:24:00 AM & 14.84 & 13.82 & 1.16 & -0.14 & 5 \\
\hline 20 & July 8, 2003 & 6:04:00 AM & 14.85 & 13.82 & 1.16 & -0.13 & 5 \\
\hline 21 & July 8, 2003 & 6:30:00 AM & 14.85 & 13.82 & 1.16 & -0.13 & 5 \\
\hline
\end{tabular}




\section{RESULTS}

\section{Measurement Frequency}

For the 1,012 trucks, net exposure rates at $1 \mathrm{~m}(3.3 \mathrm{ft})$, either derived from gross measurements from the PIC array or from hand-held measurements for trucks with gross readings greater than $800 \mu \mathrm{R} / \mathrm{h}$, range from -6.65 to $11,970 \mu \mathrm{R} / \mathrm{h}(11.9 \mathrm{mR} / \mathrm{h})($ Appendix). For nearly half of the trucks measured (483 or 47.7 percent), net exposure values were equal to or less than zero, indicating that the measurement at the PIC array was indistinguishable from background (Figure 9 and Table 6). Consequently, these trucks represented no potential net exposure to the public. Any net exposure value of less than zero was subsequently set to zero in the database ("Adjusted Exposure" column in Appendix) for cumulative exposure calculations. An additional 206 trucks (20.4 percent) had net exposure values ranging between 0 and $1 \mu \mathrm{R} / \mathrm{h}$. Thus, a total of 689 trucks (68.1 percent) had values less than or equal to $1 \mu \mathrm{R} / \mathrm{h}$. The nonGaussian nature of the dataset is evident in Figure 9 and in Table 6. It is also evident in cumulative exposure measurements that are dominated by the small number of trucks (e.g., the 59 trucks) above $800 \mu \mathrm{R} / \mathrm{hr}$.

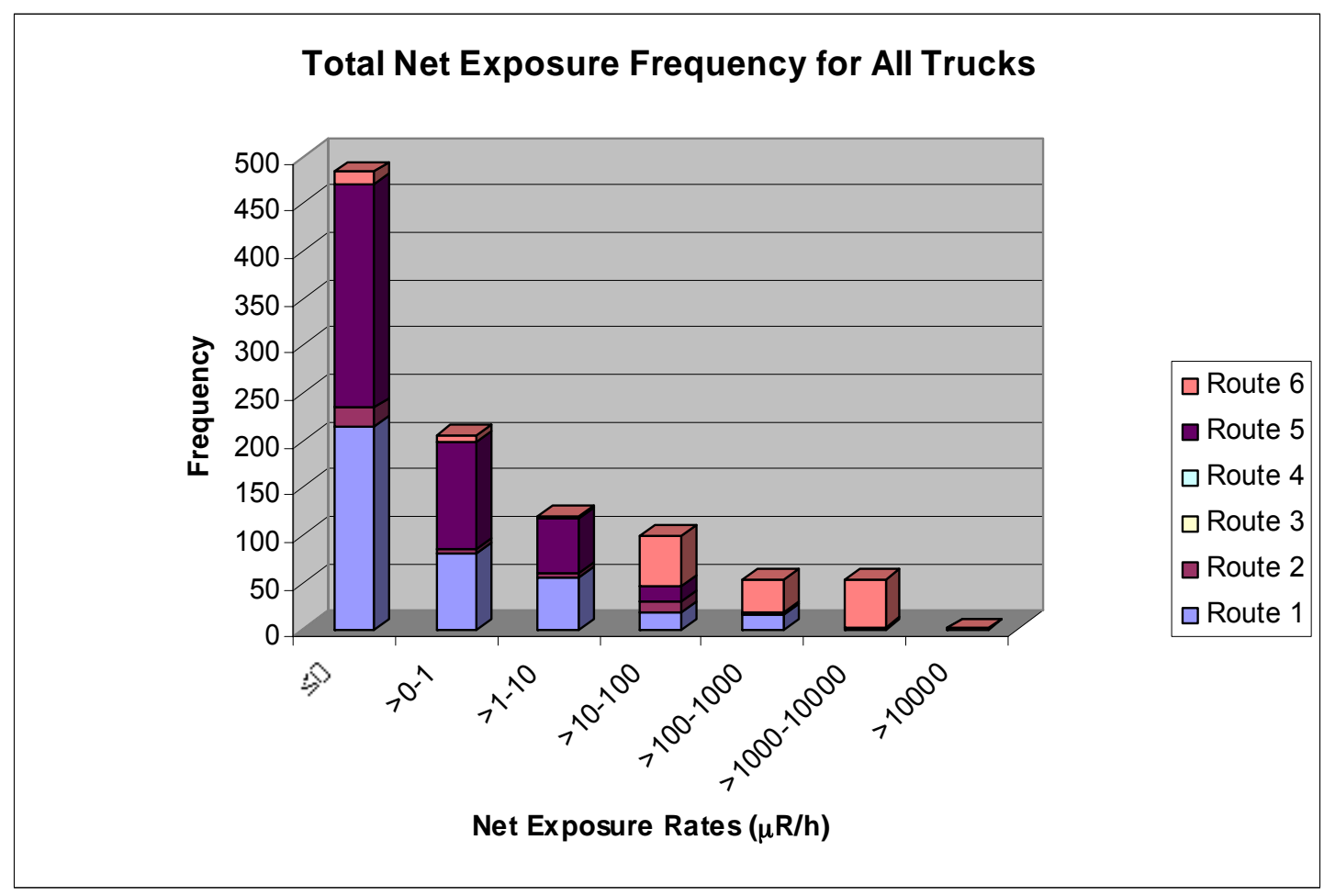

Figure 9. Net exposure measurement frequency for all 1,012 trucks measured during the study using the average background and standard deviation. The absolute number of trucks per increment of exposure measured at the PIC array and RWMC is shown in Table 6. 
Table 6. The absolute number of trucks per increment of net exposure.

\begin{tabular}{lcccccc}
\hline $\begin{array}{c}\text { Net Exposure } \\
\text { Range in } \mu \mathrm{R} / \mathrm{h}\end{array}$ & $\begin{array}{c}\text { Total } \\
\text { Number of } \\
\text { Trucks }\end{array}$ & $\begin{array}{c}\text { Number of } \\
\text { Trucks on } \\
\text { Route } 1\end{array}$ & $\begin{array}{c}\text { Number of } \\
\text { Trucks on } \\
\text { Route 2 }\end{array}$ & $\begin{array}{c}\text { Number of } \\
\text { Trucks on } \\
\text { Route } 5\end{array}$ & $\begin{array}{c}\text { Number of } \\
\text { Trucks on } \\
\text { Route } 6\end{array}$ & $\begin{array}{c}\text { Number of } \\
\text { Trucks on } \\
\text { Route 5/6 }\end{array}$ \\
\hline$\leq 0$ & 483 & 215 & 19 & 237 & 12 & 249 \\
$>0-1$ & 206 & 80 & 6 & 113 & 7 & 120 \\
$>1-10$ & 120 & 56 & 3 & 58 & 3 & 61 \\
$>10-100$ & 94 & 18 & 12 & 15 & 53 & 68 \\
$>100-1,000$ & 55 & 15 & 1 & 2 & 35 & 37 \\
$>1,000-10,000$ & 53 & 0 & 0 & 2 & 51 & 53 \\
$>10,000$ & 1 & 0 & 0 & 0 & 1 & 1 \\
\hline TOTAL & 1,012 & 384 & 41 & 427 & 162 & 589 \\
\hline
\end{tabular}

While there are some trucks in the database (e.g., the 59 trucks greater than $800 \mu \mathrm{R} / \mathrm{h}$ ) with comparatively high readings, the potential net exposure values for all 1,012 trucks are far below any regulatory limits. There are no standards per se for potential exposure from LLW shipments at $1.0 \mathrm{~m}(3.3 \mathrm{ft})$. However, as previously discussed, DOT has a shipping standard at $2.0 \mathrm{~m}(6.6 \mathrm{ft})$ distance of $10 \mathrm{mrem} / \mathrm{h}(10,000 \mu \mathrm{R} / \mathrm{h})$. Assuming a one-to-one correspondence between Roentgens and Rems (Shleien et al., 1998), then 903 trucks (89.2 percent of the trucks measured) were no greater than one percent of the DOT standard at $1.0 \mathrm{~m}(3.3 \mathrm{ft})$. Had the distance at which the trucks been measured increased to $2.0 \mathrm{~m}$ $(6.6 \mathrm{ft})$, the net exposure would be even less because of the increase in distance between the truck and the receptor. However, based on the empirical data from this study for trucks with gross measurement reading greater than $800 \mu \mathrm{R} / \mathrm{h}$, the rate of decrease may be slower than for either a point or line source. The highest adjusted net value, $11.9 \mathrm{mR} / \mathrm{h}$, came from the only truck with a value greater than $10 \mathrm{mR} / \mathrm{hr}$.

\section{Potential Cumulative Exposure Scenarios}

To address a concern of some stakeholders in rural communities along transportation routes of cumulative exposure, several cumulative exposure scenarios were developed for members of the public. Some scenarios assumed trucks were traveling at slower speeds through rural towns and were required to stop at a light or stop sign along the roadway. Also, scenarios were developed for situations in which the truck driver parked his or her vehicle for various periods of time. Exposure scenarios are described in Table 6. It should be noted that the cumulative exposure scenarios represent the highly unlikely case that the same individual would be in proximity to each of the LLW trucks that traveled through particular towns along the LLW transportation routes; however, the exposure scenarios were developed to apply to the aforementioned "reference man." As a point of comparison, the cumulative exposure values are compared to the ICRP and 10CFR834 Subpart B public dose limit of $100 \mathrm{mrem} / \mathrm{y}$ from a licensed facility, assuming a one-to-one correspondence between Roentgens and Rems (Shleien et al., 1998).

One of the concerns of stakeholders in rural communities along transportation routes is incremental exposure from the passage of LLW trucks along "Main Street." That is, when the transportation route and the main road in the town are the same, the potential of a person 
being exposed to LLW truck shipments at a distance of $1.0 \mathrm{~m}(3.3 \mathrm{ft})$ is increased. The exposure scenarios (Table 7) were developed to address issues of cumulative potential exposure. Total exposure of the individual in any of the scenarios is determined by the product of the quantity of the potential exposure time $(h)$, the net exposure rate $(\mu R / h)$, summed for all the trucks an individual is exposed to (net being the difference between the maximum PIC reading for the truck and the appropriate background value and standard deviation measured by the PICs), and the distance between the trailer and the individual.

Table 7. Potential exposure scenarios for members of the public in rural towns in Nevada and Utah along transportation routes to the NTS.

\begin{tabular}{|c|c|c|c|}
\hline $\begin{array}{l}\text { Scenario } \\
\text { Number }\end{array}$ & Scenario & Distance & $\begin{array}{c}\text { Potential } \\
\text { Exposure Time }\end{array}$ \\
\hline 1 & $\begin{array}{l}\text { A truck travels slowly through town, past an individual } \\
\text { ("Reference Man" - Davis et al., [2002]) standing on the } \\
\text { sidewalk. }\end{array}$ & $1.0 \mathrm{~m}$ & $15 \mathrm{sec}$ \\
\hline 2 & $\begin{array}{l}\text { An individual is parked at a stoplight, adjacent to a LLW } \\
\text { truck trailer. }\end{array}$ & $1.0 \mathrm{~m}$ & $1 \mathrm{~min}$ \\
\hline 3 & The driver stops for fuel, with an attendant dispensing fuel. & $1.0 \mathrm{~m}$ & $0.5 \mathrm{hr}$ \\
\hline 4 & The driver stops for a meal, parking along the curb. & $1.0 \mathrm{~m}$ & $1 \mathrm{hr}$ \\
\hline 5 & $\begin{array}{l}\text { The truck driver stops at a roadside rest area to sleep } \\
\text { overnight. }\end{array}$ & $1.0 \mathrm{~m}^{*}$ & $8 \mathrm{hrs}$ \\
\hline
\end{tabular}

Total cumulative exposure of an individual for each route and town along the routes was calculated for each of the five scenarios (Table 8 and Figures 10a through 10e). The values in the table assume that for Scenario 1, as an example, the same individual is present for $15 \mathrm{sec}$ when each LLW truck goes through town. In Scenario 4, the "reference man" is assumed to be a diner sitting at a window table of a street-front restaurant when a LLW truck is parked along the curb while the driver stops for an hour-long meal. The occupant of an adjacent vehicle parked at a roadside rest area, where the LLW truck driver stops to sleep overnight for eight hours, is the presumed "reference man" in Scenario 5. Pahrump and Amargosa Valley exposures are for only the trucks along Routes 1 and 2, respectively. Exposures for Routes 5 and 6 are segregated, as the portion of these routes in Utah before reaching Nevada is different (Delta for Route 5 versus West Wendover and Salt Lake City for Route 6). However, as the routes converged in Nevada, a cumulative exposure for Route 5/6 was developed and is the appropriate cumulative exposure value for both Ely and Tonopah, as well as towns such as Beatty and Goldfield along U.S. Highway 95 between Tonopah and the entrance to the NTS. A total exposure for "all" trucks is calculated for Mercury, located at the NTS, as all LLW trucks pass through this location on the way to the waste management sites on the NTS. For cumulative measurements, trucks with a negative net exposure value were assigned an "adjusted net exposure" of $0.0 \mu \mathrm{R} / \mathrm{h}$ (see Appendix). 
Table 8. Total exposures ( $\mathrm{mR}$ ) for each scenario by route and town. Cumulative exposure values are for a reference man, and assume the highly unlikely event that the same person is present for each truck along each route for the respective scenarios.

\begin{tabular}{|c|c|c|c|c|c|c|c|}
\hline \multirow[b]{3}{*}{ Route } & \multirow[b]{3}{*}{ Town } & \multirow[b]{3}{*}{$\begin{array}{l}\text { No. of } \\
\text { Trucks }\end{array}$} & \multicolumn{5}{|c|}{ Scenario } \\
\hline & & & 1 & 2 & 3 & 4 & 5 \\
\hline & & & $\begin{array}{l}15-\mathrm{sec} \\
@ 1 \mathrm{~m}\end{array}$ & $\begin{array}{l}1 \mathrm{~min} \\
\text { (a) } 1 \mathrm{~m}\end{array}$ & $\begin{array}{l}0.5 \mathrm{hr} \\
@ 1 \mathrm{~m}\end{array}$ & $\begin{array}{l}1 \mathrm{hr} \\
\text { (a) } 1 \mathrm{~m}\end{array}$ & $\begin{array}{l}8 \mathrm{hr} \\
@ 1 \mathrm{~m}\end{array}$ \\
\hline 1 & Pahrump, NV & 384 & 0.0 & 0.1 & 1.9 & 3.8 & 30.3 \\
\hline 2 & Amargosa Valley, NV & 42 & 0.0 & 0.0 & 0.4 & 0.7 & 5.8 \\
\hline 3 & Caliente, NV & 0 & 0.0 & 0.0 & 0.0 & 0.0 & 0.0 \\
\hline 4 & Tonopah, NV & 0 & 0.0 & 0.0 & 0.0 & 0.0 & 0.0 \\
\hline 5 & $\begin{array}{l}\text { Delta, UT/ Ely/ } \\
\text { Tonopah, NV }\end{array}$ & 427 & 0.0 & 0.1 & 3.5 & 7.0 & 56.2 \\
\hline 6 & $\begin{array}{l}\text { Salt Lake City, UT/ } \\
\text { Ely/ Tonopah, NV }\end{array}$ & 162 & 0.8 & 3.2 & 96.7 & 193.4 & $1,547.1$ \\
\hline $5 / 6^{*}$ & Ely/Tonopah, NV & 586 & 0.8 & 3.3 & 100.20 & 200.4 & $1,603.2$ \\
\hline All & Mercury, NV & 1,012 & 0.8 & 3.4 & 102.5 & 204.9 & $1,639.3$ \\
\hline
\end{tabular}

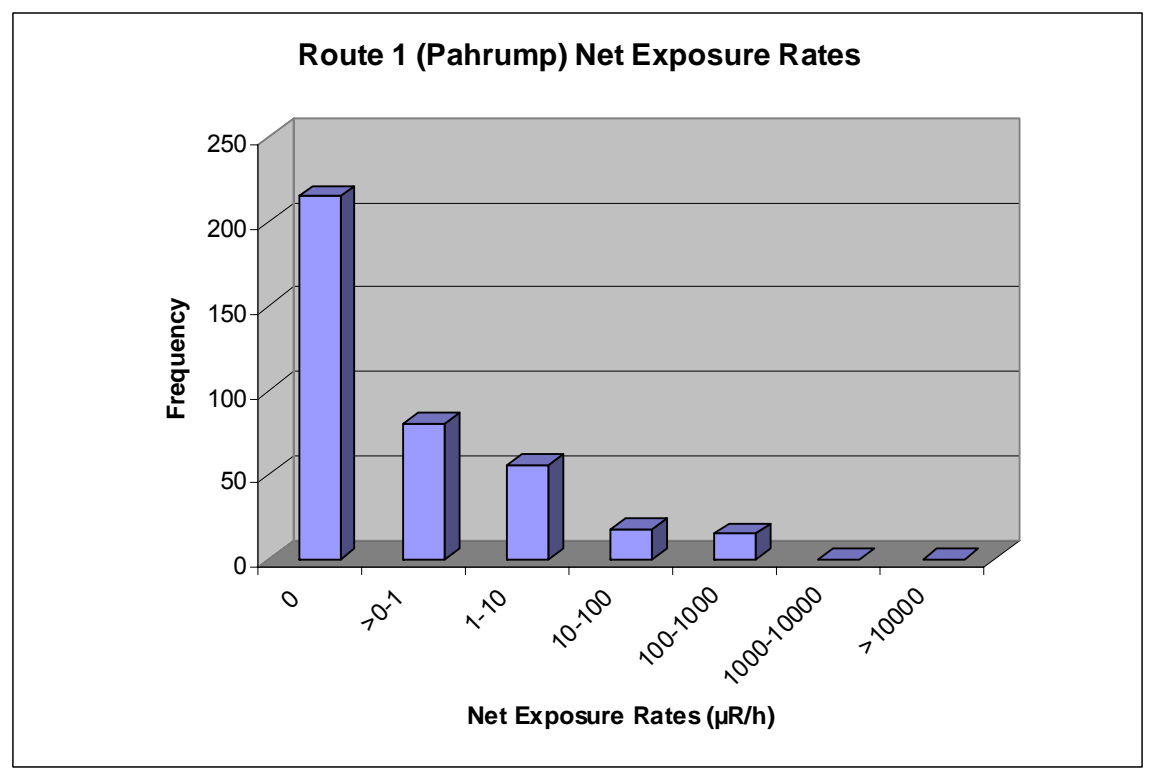

Figure 10a. Measurement frequency of the 384 trucks that traveled through Pahrump, NV (Route 1), compared to net exposure ranges in $\mu \mathrm{R} / \mathrm{h}$. 


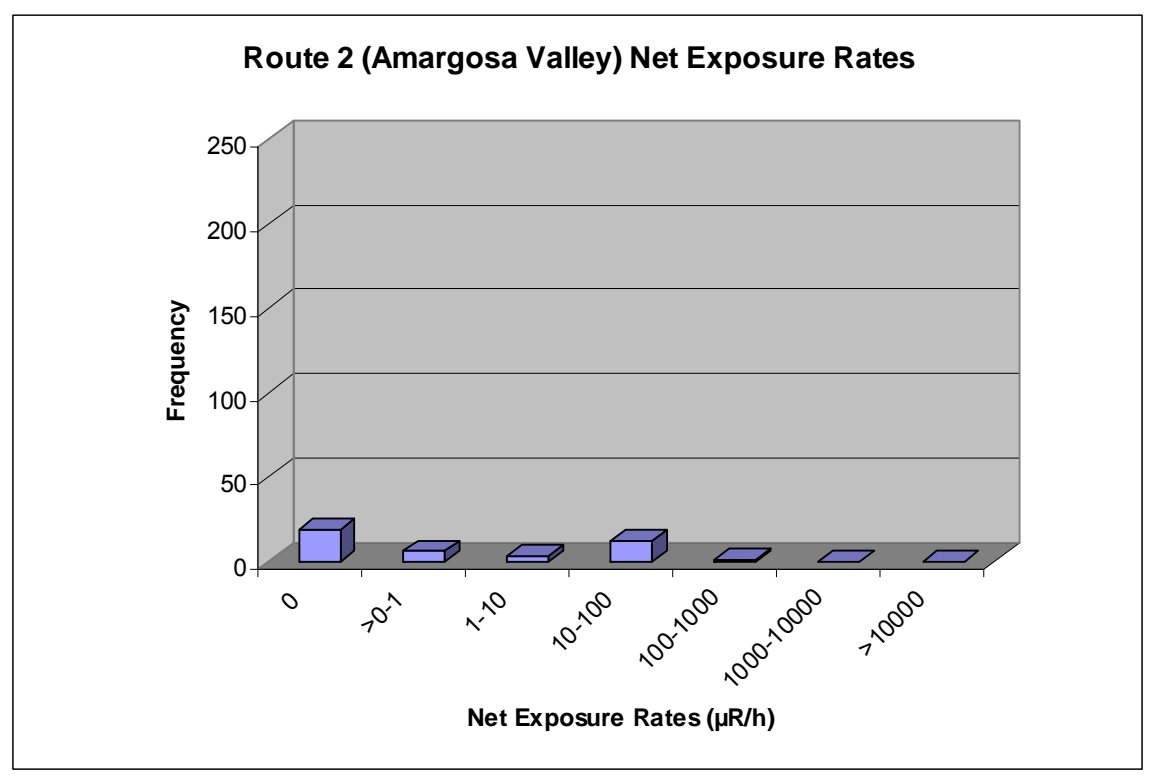

Figure 10b. Measurement frequency of the 42 trucks that traveled through Amargosa Valley, NV (Route 2), compared to net exposure ranges in $\mu \mathrm{R} / \mathrm{h}$.

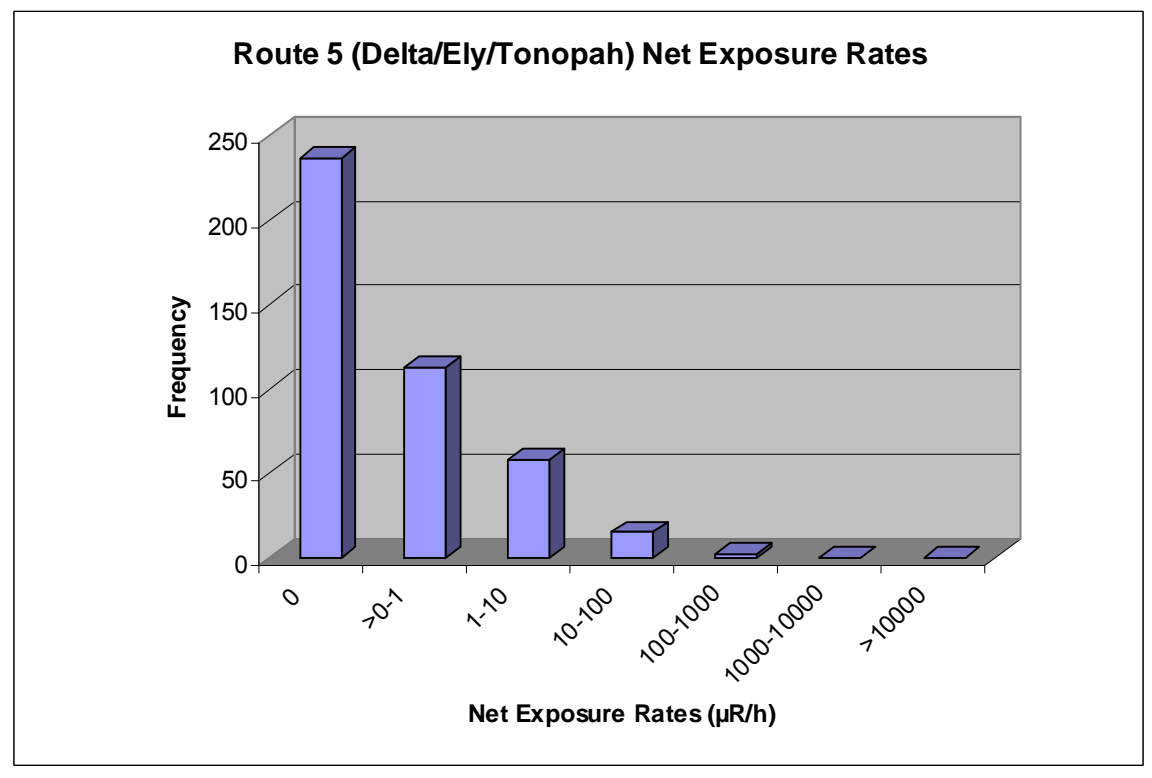

Figure 10c. Measurement frequency of the 427 trucks that traveled through Delta, UT, and Tonopah, NV (Route 5), compared to net exposure ranges in $\mu \mathrm{R} / \mathrm{h}$. 


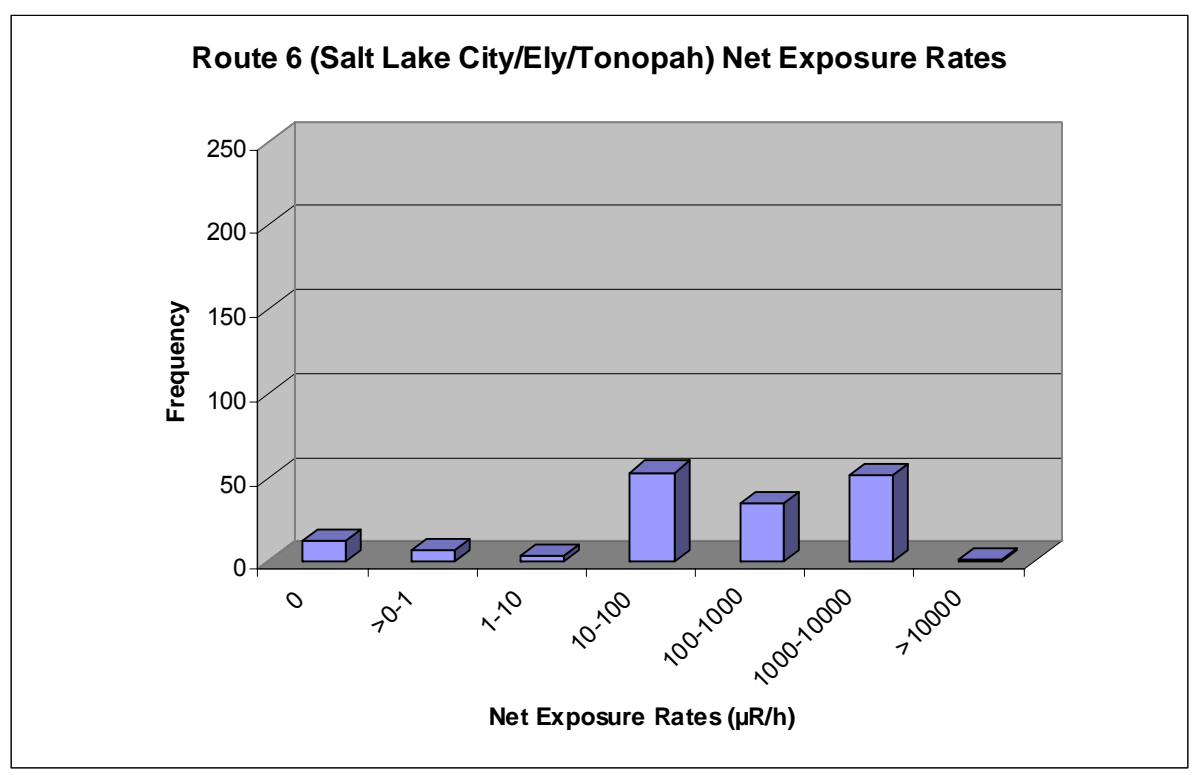

Figure 10d. Measurement frequency of the 162 trucks that traveled through Salt Lake City, UT, and Tonopah and Ely, NV (Route 6), compared to net exposure ranges in $\mu \mathrm{R} / \mathrm{h}$.

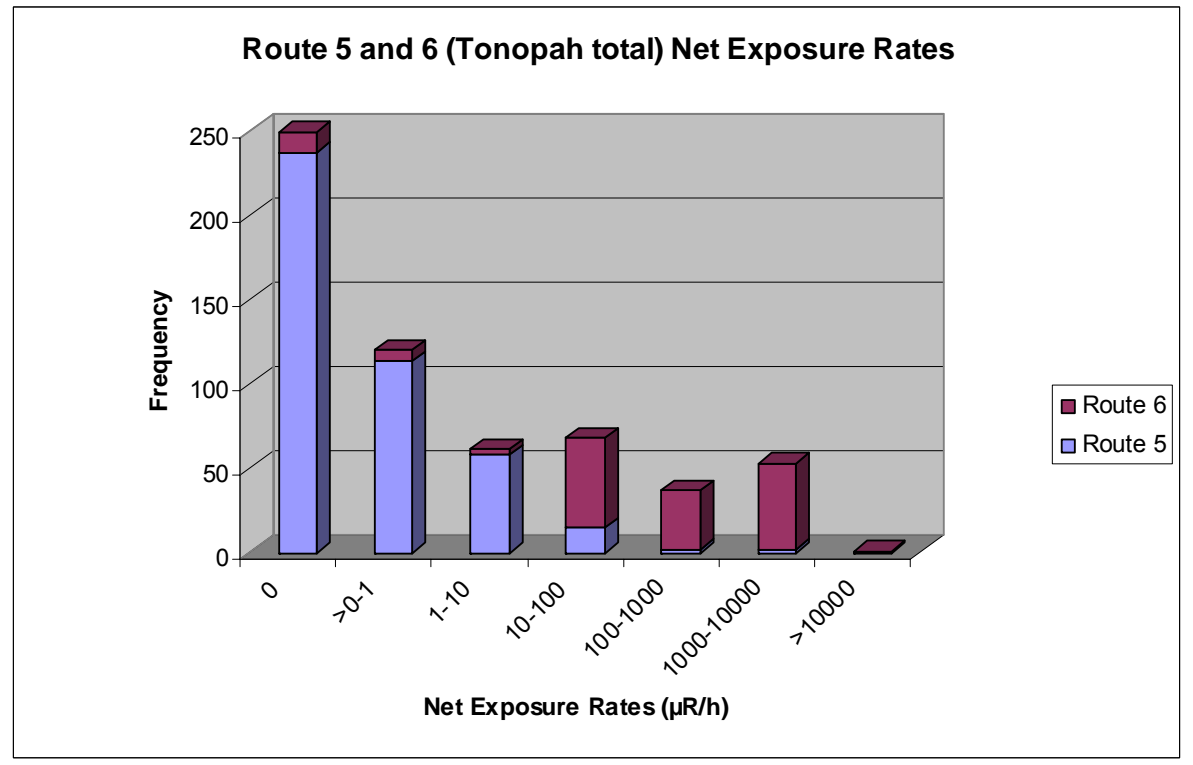

Figure 10e. Measurement frequency of the 587 trucks that traveled through combined Tonopah, $\mathrm{NV}$, total (Routes 5 and 6) compared to net exposure ranges in $\mu \mathrm{R} / \mathrm{h}$.

Scenario 1, where a member of the public is exposed to a LLW truck for a period of $15 \mathrm{sec}$, is based on a scenario used by NNSA/NSO from Davis et al. (2002) in discussing potential exposure and dose to pedestrians. However, Davis et al. (2002) extrapolate exposure and dose measurements from $1.0 \mathrm{~m}(3.3 \mathrm{ft})$ to $2.0 \mathrm{~m}(6.6 \mathrm{ft})$ based on treatment of the truck as a line source, a technique not supported by analysis of the greater than $800 \mu \mathrm{R} / \mathrm{h}$ 
trucks examined herein. Consequently, the data presented herein for this cumulative exposure scenario are based on an exposure at $1.0 \mathrm{~m}(3.3 \mathrm{ft})$ distance. As an example, if a person was along the side of the road when each of the 42 trucks measured from Route 2 went through Amargosa Valley, assuming the 15-sec exposure (0.0042 h) of Scenario 1, his or her cumulative exposure would be $3.0 \mu \mathrm{R}$. However, Amargosa Valley is a good example of the sensitivity of the higher measurements on total cumulative exposure. If the highest net exposure reading of $259.2 \mu \mathrm{R} / \mathrm{h}$ is removed from the calculation, then the cumulative exposure for Scenario 1 is reduced to $2.0 \mu \mathrm{R}$, or only 66 percent of the original cumulative exposure.

Figures 10c and 10d, combined with the results of Table 8, illustrate that total exposure is not simply a function of the total trucks along a given route. For example, 427 shipments were transported along Route 5, through Delta, Utah, whereas only 162 shipments were transported along Route 6, through Salt Lake City, Utah. However, as shown in Table 8 , the total net exposure for Route 6 is over 27 times that for Route 5, as is the cumulative exposure rate in each scenario. Review of Figures $10 \mathrm{c}, 10 \mathrm{~d}$, and $10 \mathrm{e}$ clearly demonstrates the difference in the distribution of the exposure rates for the trucks on these routes, with Route 6 showing the majority of the trucks having comparatively higher net exposure rates, whereas Route 5 has the majority of the trucks with lower net exposure rates.

Members of the public who are servicing LLW trucks en route to the NTS might receive some of the higher cumulative exposures. In Table 8, Scenario 3 for the combined truck traffic along Routes 5 and 6 through Ely and Tonopah might represent an attendant at a fuel station for trucks in either town. According to the cumulative exposure calculation for this scenario, such a person might receive $100 \mathrm{mR}$, the allowable exposure to a member of the public, after servicing the nearly 600 trucks that traveled through these towns. Again, this exposure is for a "reference man," as it is highly unlikely that only one attendant would be servicing all of the trucks.

\section{Potential Individual Exposure Probabilities}

A probability of an individual receiving exposure from a truck, rather than a "reference man" cumulative exposure, may be a more meaningful perspective to an individual living in one of the communities along the transportation routes. In addition, examining the probability of an individual receiving an exposure from a LLW truck also exhibits the nonGaussian nature of the data. For each of the five scenarios, the actual amount of time when an exposure might occur is comparatively short and there were long periods of times (sometimes multiple days) between trucks being recorded at the PIC array. In other words, at any one time, it is far more likely that a truck is not present as opposed to being present. However, for this exercise, the assumption is made that an individual is present within $1.0 \mathrm{~m}(3.3 \mathrm{ft})$ of a truck when it passed through their town; thus, the potential for exposure is assumed to exist.

Table 9 shows the probability that an individual might receive a net exposure from any single truck in towns along the various routes. In addition, as previously discussed, a small number of trucks contribute the majority of potential cumulative exposures, but the probability of being exposed to one of those trucks is low. For example, of the 587 LLW trucks that traveled through Tonopah, 340 of these trucks had net exposure rates greater than $0 \mu \mathrm{R} / \mathrm{h}$, and 54 of the trucks had net exposure rates greater than or equal to $1,000 \mu \mathrm{R} / \mathrm{h}$. This 
results in the probability of an individual in Tonopah receiving a potential net exposure from any single truck to be 0.58 , and to a truck with a net exposure rate greater than or equal to $1,000 \mu \mathrm{R} / \mathrm{h}$ to be only 0.09 .

In Table 9 it is assumed that an individual is present when a truck is present; however, there are far more times when a LLW truck is not present. If the individual exposure probabilities are put within context of the time periods used within the scenarios, the probability that an individual would receive an exposure from a LLW truck becomes, in reality, quite small. For example, in Table 9, the time period of $1 \mathrm{~min}$ of potential exposure at $1 \mathrm{~m}$ distance is used. As there are 525,600 minutes in a 365-day year, the probability of an individual being available to a potential exposure during a single 1-min time period in a given year is $1.9 \mathrm{E}-6$. Therefore, the probability of an individual in Pahrump receiving a potential net exposure to any single truck during any specific 1-min time period within a given year is the product of the probabilities of exposure and time, or 8.4E-7. Summing all of the reasonable probabilities of an individual being exposed results in a small probability of a net exposure to an individual.

Table 9. Probability of a potential net exposure to an individual within a specific town from any single truck or to a truck with a net exposure greater than or equal to1,000 $\mu \mathrm{R} / \mathrm{h}$.

\begin{tabular}{|c|c|c|c|}
\hline CEMP Town & $\begin{array}{c}\text { Total } \\
\text { number of } \\
\text { LLW trucks }\end{array}$ & $\begin{array}{l}\text { Total number of LLW } \\
\text { trucks with net exposure } \\
\text { above } \\
\text { zero } \mu \mathrm{R} / \mathrm{h}\end{array}$ & $\begin{array}{l}\text { Total number of LLW trucks } \\
\text { with net exposure } \\
\geq 1,000 \mu \mathrm{R} / \mathrm{h}\end{array}$ \\
\hline Pahrump & 384 & 169 & 0 \\
\hline Amargosa Valley & 41 & 22 & 0 \\
\hline Delta/Ely/Tonopah & 427 & 190 & 2 \\
\hline $\begin{array}{l}\text { Salt Lake City/ } \\
\text { Ely/Tonopah }\end{array}$ & 164 & 150 & 52 \\
\hline Ely/Tonopah (Total) & 587 & 340 & 54 \\
\hline Mercury & 1,012 & 529 & 54 \\
\hline CEMP Town & $\begin{array}{r}\text { Probability } \\
\text { fror }\end{array}$ & $\begin{array}{l}\text { f a potential net exposure } \\
\text { a any single truck }\end{array}$ & $\begin{array}{c}\text { Probability of an exposure from } \\
\text { a truck with rate } \\
\geq 1,000 \mu \mathrm{R} / \mathrm{h}\end{array}$ \\
\hline Pahrump & & 0.44 & 0.00 \\
\hline Amargosa Valley & & 0.54 & 0.00 \\
\hline Delta/Ely/Tonopah & & 0.44 & 0.01 \\
\hline $\begin{array}{l}\text { Salt Lake City/ } \\
\text { Ely/Tonopah }\end{array}$ & & 0.93 & 0.32 \\
\hline Ely/Tonopah (Total) & & 0.58 & 0.09 \\
\hline Mercury & & 0.52 & 0.05 \\
\hline
\end{tabular}




\section{DISCUSSION AND CONCLUSIONS}

This study has shown that, based upon measurements from industry standard radiation detection instruments, such as the RS model RSS-131 PICs in a controlled configuration, a person may be exposed to gamma radiation above background when in close proximity to some LLW trucks. However, in approximately half (47.7 percent) the population of trucks measured in this study, a person would receive no exposure above background at a distance of $1.0 \mathrm{~m}(3.3 \mathrm{ft})$ away from a LLW truck. An additional 206 trucks had net exposures greater than zero, but equal to or less than $1 \mu \mathrm{R} / \mathrm{h}$. Finally, nearly 80 percent of the population of trucks $(802$ of 1,012) had net exposures less than or equal to $10 \mu \mathrm{R} / \mathrm{h}$. Although there are no shipping or exposure standards at $1.0 \mathrm{~m}(3.3 \mathrm{ft})$ distance, one relevant point of comparison is the DOT shipping standard of $10 \mathrm{mrem} / \mathrm{h}$ at $2.0 \mathrm{~m}(6.6 \mathrm{ft})$ distance. Assuming a one-to-one correspondence between Roentgens and Rems, then 903 trucks (89.2 percent of the trucks measured) were no greater than one percent of the DOT standard at $1.0 \mathrm{~m}(3.3 \mathrm{ft})$. Had the distance at which the trucks been measured increased to $2.0 \mathrm{~m}(6.6 \mathrm{ft})$, the net exposure would be even less because of the increase in distance between the truck and the receptor. However, based on the empirical data from this study, the rate of decrease may be slower than for either a point or line source as was done for previous studies (Gertz, 2001; Davis et al., 2001). The highest net exposure value at $1.0 \mathrm{~m} \mathrm{(3.3 \textrm {ft } )}$ distance, $11.9 \mathrm{mR} / \mathrm{h}$, came from the only truck with a value greater than $10 \mathrm{mR} / \mathrm{h}$ at $1.0 \mathrm{~m}$ $(3.3 \mathrm{ft})$ distance.

The results compare favorably with conclusions from Gertz (2001) in which it was estimated that 90 percent of the LLW trucks coming to the NTS were at or below background in terms of net exposure. However, Gertz (2001) used a standard background on the NTS of $50 \mu \mathrm{R} / \mathrm{h}$ (with no standard deviation), a value appropriate for use at the disposal sites, but considerably higher than typical background measurements at the PIC array or for towns along transportation routes in the region. In addition, in the earlier study, a smaller data set (88 trucks) was used. Nevertheless, if the dataset described herein was analyzed for net exposure using the $50 \mu \mathrm{R} / \mathrm{h}$ background value, then 84.5 percent of the trucks would be below background, a result not altogether different than the estimate in Gertz (2001). However, the value of this study includes the larger population of trucks measured, the fact that they were in transit when measured, plus the use of background values particular to when each truck arrived. The authors are unaware of any study of such a large number of trucks for which systematic measurements were taken while the vehicles were in transit.

For cumulative exposure scenarios, the $100 \mathrm{mrem} / \mathrm{y}$ standard of the EPA in 10CFR834 Part B for a licensed facility (excluding exposures from radon and medical devices) was used as a basis of comparison. The comparison assumes a one-to-one correspondence between Roentgens and Rems (Shleien et al., 1998). Even when cumulative exposures are calculated for short exposures of time (for example, Scenario 1), the results are still a small percentage of the 10CFR834 Subpart B public dose limit. However, when calculating cumulative exposures for different scenarios, the results can be strongly sensitive to a relatively few high measurements. Only 5.3 percent of the trucks measured in this study had external readings exceeding $1,000 \mu \mathrm{R} / \mathrm{h}$. Nevertheless, as illustrated in the comparison of the average exposure from a 15-sec period of a pedestrian along side of a LLW truck in Amargosa Valley, including or excluding one higher value can significantly change the cumulative exposure rate. 
Although the results of this study indicate that individual truck and cumulative exposure measurements were well below relevant DOT and EPA standards, it is recommended that NNSA/NSO update some information that it presents to the public on LLW transportation to the NTS. For example, if the measurements collected during this study are representative, then the result of the highest "actual NTS shipment" of $1,000 \mu \mathrm{R}$ at contact with the truck, as reported in Davis et al. (2002), is now on the low side. This conclusion is reached by examining the PIC data, but also demonstrated in the manual measurements taken by RCTs at the Area 3 RWMS and Area 5 RWMC at the NTS. In addition, when examining the entire population of trucks, the distribution is nonGaussian. Consequently, an "average" truck is not an appropriate statistical measure. Instead, it may be more appropriate to talk about three populations of trucks. The first and the largest is those that represent no potential exposure (47.7 percent). The second is those close to zero (20.4 percent with positive net exposures rates less than $1 \mu \mathrm{R} / \mathrm{h}$ ). Finally, the smallest population is those that dominate cumulative exposure measurements, i.e., the 5.3 percent of trucks with net exposure rates greater than $1,000 \mu \mathrm{R} / \mathrm{h}$.

The results presented herein on differences in the number of trucks and cumulative exposure along particular routes to the NTS should only be considered a snapshot in time. Nevertheless, some trends may continue for the next few years with the accelerated closure of DOE sites. That is, the number of shipments and total potential exposure along routes through Nevada towns such as Ely, Tonopah, Beatty, and Goldfield are likely to remain higher than shipments through Amargosa Valley or Pahrump. However, the potential exposure will be dependent upon the waste type, an aspect that was not analyzed in this study because of the voluntary nature of the study and the decision not to identify waste generators.

\section{RECOMMENDATIONS}

As previously mentioned, nearly all investigations regarding exposure from LLW truck transportation involved calculated versus measured exposures and doses. In fact, in searching the literature, and in talking with others in the waste transportation field, the authors were not able to identify another project where such a large population of LLW trucks, particularly during transport, was systematically measured as was done for this study. Certainly, at radioactive waste management facilities, including the RWMC and RWMS at the NTS, RCTs take measurements with hand-held instruments to compare against DOT shipping standards. However, the data quality objectives of those measurements do not require the same level of precision that was the goal of this study.

Nevertheless, if further investigations of this type are performed, the following are some lessons-learned that may be included in future studies:

1. Use a traffic counter for recording when trucks entered the PIC array. A common error made by truck drivers was to record the time at the place of waste origin when they arrived at the PIC array, rather than that of the Pacific Time Zone. While these errors in time zone were corrected, the number of logbook errors and the amount of time necessary to make the corrections were underestimated. The number of errors might be reduced by using a traffic counter tied to a datalogger. The traffic counter would also be another line of evidence for cases where it is suspected that a LLW truck entered the PIC array, but the driver recorded no information about the shipment. 
2. If possible, do measurements at a facility where there is more control over participation of drivers in the study. It would have been ideal, but prohibitively expensive, to have a person at the NTS PIC facility to guide drivers through the process and make certain that data on the waste shipment were all correctly recorded in the logbook. For a future study that involved multiple means of transport of shipping containers, an intermodal facility might be an ideal location. All carriers would need to stop, and likely there would be personnel present at all times whom could assist with the quality of the data that are recorded about the waste shipment that would accompany the exposure measurements taken.

3. Measurements taken at an intermodal facility could also allow a larger number of measurements to be taken of the trucks. One of the values in automating the PIC array for this study, and having radiation instruments that stabilized quickly when a truck arrived, is that the amount of time required by the truck drivers to participate in the study was small. In talking to truck drivers who used it, the fact that little time was required for them to participate in the study was an important reason for using the PIC array. However, it resulted in relatively few measurements for each truck. In contrast, the number of measurements of background was significant and far more could be done statistically with these values. At an intermodal facility, it might be possible to collect a larger number of measurements for each truck and improve the analytical value of the gross measurement readings.

4. Explore alternative instruments for recording higher gamma readings or taking measurements with multiple instruments with different total gamma sensitivity ranges. The RS model RSS-131 high pressure PICs were used in large part because they are cost effective and widely used for offsite monitoring around the NTS and at other DOE sites and facilities. In addition, because it is an important instrument used by the CEMP for gamma radiation measurements, stakeholders in many rural towns along LLW transportation routes to the NTS are familiar with the output of the instrument. In designing the study, DRI emphasized the ability to measure relatively small net gamma readings because of the assumption (true in most cases) that if a LLW truck was detectable above background, it would not significantly exceed background.

However, choosing this model PIC created problems for the gross measurement for the 59 trucks at the PIC array exceeded approximately $800 \mu \mathrm{R} / \mathrm{h}$. A possible approach in the future would be to combine measurements from one instrument sensitive to the lower-range end of gamma measurements with measurements from one more sensitive to higher net gamma readings. While rare, the trucks with higher external gamma measurements contribute significantly to cumulative exposure measures. Consequently, it is important that these few higher measurements be as accurate as possible.

5. As previously discussed, in the examination of trucks with exposure values greater than $800 \mu \mathrm{R} / \mathrm{h}$, the decrease in values with increasing distance from the truck may be much slower than would be predicted for a point or even a line source. No references were found discussing this phenomenon; thus, it is recommended that this phenomenon specifically be investigated. This could be done with a mobile PIC, taking various measurements versus distance with one or more LLW trucks. The 
trucks would need to have similar characteristic waste loads (probably randomly distributed heterogeneous packages, constituting a large bulky source such as measured in this study at the PIC array and at the Area 5 RWMC and Area 3 RWMS). Radiation readings would need to be sufficiently high to obtain readings from at least $2.0 \mathrm{~m}(6.6 \mathrm{ft})$ distance away from the truck.

6. A slightly larger database could have been created had the truck drivers more accurately recorded information about their shipment. Although DOT shipping standards require that a driver be able to furnish and have readily at hand information such as the WSIN in the event of an accident or other emergency, it is not at all clear from this study that all drivers sufficiently understand their shipping documentation. For a future study of this type, part of the instructions to waste generators could be to brief their drivers on where to find the pertinent information they will need to provide at the point where external exposure readings of the truck will be measured. Alternatively, waste generators could develop a card specifically designed for the transportation study that the driver would carry en route. When the driver arrived at the PIC array, he or she would time-punch the card and leave it in a drop box. While such an approach would increase up-front time and costs, it would significantly reduce the time spent reconstructing missing information as well as potentially increasing the percent of shipments for which exposure data are collected.

\section{REFERENCES}

Campbell Scientific, 1997. CR10X Measurement and Control System Operator's Manual.

Davis, M., A.E. Hechanova and G.S. Cerefice, 2002. Doses from the transportation of radioactive waste. Presentation to the Clark County Yucca Mountain Nuclear Waste Advisory Committee, Las Vegas.

DiSanza, E.F., 2002. Assessing exposure to the public from transporting low-level radioactive waste (LLW) to the Nevada Test Site. Letter to approved Nevada Test Site waste generators, NNSA/NV, November 18, 2002.

Gertz, C.P., 2001. Overview of low-level waste transportation and disposal. U.S. Department of Energy Nevada Operations Office, Las Vegas. 32pp.

Hartwell, W.T., D.S. Shafer, R. Cullison, S. Sedano, M. Herndon, G. McCurdy, L. Karr, C. Shadel, L. Glass and R. Furlow, 2001. The Community Environmental Monitoring Program: Environmental communication and education through participation. Proceedings of Waste Management 2001. Tucson.

National Council on Radiation Protection (NCRP), 1987. Ionizing radiation exposure of the population of the United States, NCRP Report No. 93. ISBN: 0-913392-91-X.

National Council on Radiation Protection (NCRP), 1974. Specification of Gamma-Ray Brachytherapy Sources. NCRP Report No. 41. ISBN: 0-913392-23-5.

Reuter-Stokes, 2001. RSS-131 User's Manual, Revision J. 155pp.

Shebell, Peter, 2004. PIC calibration results for Desert Research Institute. U.S. Department of Homeland Security, Environmental Measurements Laboratory, New York, 3pp. 
Shleien, B., L.A. Slaback, Jr. and B. Birky, 1998. Handbook of Health Physics and Radiological Health. Lippinott Williams and Wilkins, 700pp.

Turner, J.E., 1995. Atoms, Radiation, and Radiation Protection. John Wiley and Sons, Inc., New York.

United States Department of Energy (DOE), 1999. Transporting DOE Low-Level Radioactive Waste. National Transportation Program, Albuquerque.

United States Department of Energy (DOE), 2002. Performance Management Plan, U.S. DOE National Nuclear Security Administration Nevada Operations Office, DOE/NV-831. 


\section{APPENDIX}

Gross, Net, and Adjusted Net Measurements for LLW Trucks 


\begin{tabular}{|c|c|c|c|c|c|c|c|c|}
\hline $\begin{array}{c}\text { Record } \\
\text { Number }\end{array}$ & Date of Shipment & $\begin{array}{c}\text { Time of } \\
\text { Shipment }\end{array}$ & $\begin{array}{l}\text { Gross } \\
\text { Value }\end{array}$ & $\begin{array}{l}\text { Background } \\
\text { Measurement }\end{array}$ & $\begin{array}{l}\text { Standard } \\
\text { Deviation }\end{array}$ & Net Exposure & $\begin{array}{l}\text { Adjusted } \\
\text { Net } \\
\text { Exposure }\end{array}$ & $\begin{array}{c}\text { Route } \\
\text { Number }\end{array}$ \\
\hline 1 & July 21,2003 & 4:08:00 AM & 14.84 & 14.14 & 7.35 & -6.65 & 0.00 & 5 \\
\hline 2 & July 20, 2003 & 9:18:00 PM & 15.07 & 14.14 & 7.35 & -6.42 & 0.00 & 5 \\
\hline 3 & June 22, 2003 & 11:08:00 PM & 14.84 & 14.16 & 6.90 & -6.22 & 0.00 & 2 \\
\hline 4 & May 13,2003 & 6:34:00 PM & 15.57 & 14.14 & 7.29 & -5.86 & 0.00 & 2 \\
\hline 5 & August 17, 2003 & 9:06:00 PM & 14.12 & 14.19 & 5.25 & -5.32 & 0.00 & 5 \\
\hline 6 & June 22, 2003 & 11:30:00 PM & 16.11 & 14.16 & 6.90 & -4.95 & 0.00 & 2 \\
\hline 7 & September 1, 2003 & $10: 22: 00 \mathrm{PM}$ & 14.54 & 14.13 & 4.96 & -4.55 & 0.00 & 1 \\
\hline 8 & November 13, 2003 & $7: 34: 00$ AM & 13.93 & 13.89 & 4.37 & -4.33 & 0.00 & $\begin{array}{l}1 \\
1\end{array}$ \\
\hline 9 & August 18, 2003 & 7:26:00 AM & 15.32 & 14.19 & 5.25 & -4.12 & 0.00 & 5 \\
\hline 10 & November 13, 2003 & 4:44:00 AM & 14.17 & 13.89 & 4.37 & -4.09 & 0.00 & 1 \\
\hline 11 & August 18, 2003 & 1:00:00 AM & 15.56 & 14.19 & 5.25 & -3.88 & 0.00 & 5 \\
\hline 12 & September 11, 2003 & 1:10:00 AM & 14.85 & 13.90 & 4.68 & -3.73 & 0.00 & 1 \\
\hline 13 & September 11, 2003 & 5:48:00 AM & 14.85 & 13.90 & 4.68 & -3.73 & 0.00 & 1 \\
\hline 14 & September 11, 2003 & 5:56:00 AM & 14.85 & 13.90 & 4.68 & -3.73 & 0.00 & 1 \\
\hline 15 & September 11, 2003 & 6:08:00 AM & 14.85 & 13.90 & 4.68 & -3.73 & 0.00 & 1 \\
\hline 16 & November 17, 2003 & $6: 30: 00 \mathrm{AM}$ & 14.17 & 13.74 & 4.08 & -3.65 & 0.00 & 6 \\
\hline 17 & October 12,2003 & 5:10:00 PM & 14.84 & 14.15 & 4.16 & -3.47 & 0.00 & 5 \\
\hline 18 & October 12, 2003 & 5:16:00 PM & 14.84 & 14.15 & 4.16 & -3.47 & 0.00 & 6 \\
\hline 19 & November 17, 2003 & 4:36:00 AM & 14.35 & 13.74 & 4.08 & -3.47 & 0.00 & 5 \\
\hline 20 & September 11, 2003 & 5:44:00 AM & 15.14 & 13.90 & 4.68 & -3.44 & 0.00 & 1 \\
\hline 21 & November 17, 2003 & 4:34:00 AM & 14.38 & 13.74 & 4.08 & -3.44 & 0.00 & 5 \\
\hline 22 & August 14, 2003 & $5: 12: 00$ AM & 14.61 & 13.81 & 4.23 & -3.43 & 0.00 & 1 \\
\hline 23 & August 14, 2003 & 6:04:00 AM & 14.61 & 13.81 & 4.23 & -3.43 & 0.00 & 5 \\
\hline 24 & November 13, 2003 & 7:36:00 AM & 14.84 & 13.89 & 4.37 & -3.42 & 0.00 & 1 \\
\hline 25 & November 16, 2003 & 9:28:00 PM & 14.41 & 13.74 & 4.08 & -3.41 & 0.00 & 1 \\
\hline 26 & July 23,2003 & 7:58:00 AM & 14.40 & 14.12 & 3.69 & -3.41 & 0.00 & 5 \\
\hline 27 & November 5, 2003 & 5:56:00 AM & 13.90 & 13.58 & 3.66 & -3.34 & 0.00 & 5 \\
\hline 28 & August 14, 2003 & 6:06:00 AM & 14.84 & 13.81 & 4.23 & -3.20 & 0.00 & 5 \\
\hline 29 & July 21, 2003 & $12: 44: 00 \mathrm{AM}$ & 18.30 & 14.14 & 7.35 & -3.19 & 0.00 & 5 \\
\hline 30 & August 14, 2003 & 5:50:00 AM & 15.08 & 13.81 & 4.23 & -2.96 & 0.00 & 1 \\
\hline 31 & August 14, 2003 & 5:52:00 AM & 15.08 & 13.81 & 4.23 & -2.96 & 0.00 & 5 \\
\hline 32 & August 14, 2003 & 6:00:00 AM & 15.13 & 13.81 & 4.23 & -2.91 & 0.00 & 1 \\
\hline 33 & September 4, 2003 & 5:50:00 AM & 14.85 & 13.89 & 3.84 & -2.88 & 0.00 & 5 \\
\hline
\end{tabular}




\begin{tabular}{|c|c|c|c|c|c|c|c|c|}
\hline $\begin{array}{l}\text { Record } \\
\text { Number }\end{array}$ & Date of Shipment & $\begin{array}{l}\text { Time of } \\
\text { Shipment }\end{array}$ & $\begin{array}{l}\text { Gross } \\
\text { Value }\end{array}$ & $\begin{array}{l}\text { Background } \\
\text { Measurement }\end{array}$ & $\begin{array}{l}\text { Standard } \\
\text { Deviation }\end{array}$ & Net Exposure & $\begin{array}{l}\text { Adjusted } \\
\text { Net } \\
\text { Exposure } \\
\end{array}$ & $\begin{array}{c}\text { Route } \\
\text { Number }\end{array}$ \\
\hline 34 & September 4, 2003 & 6:06:00 AM & 14.85 & 13.89 & 3.84 & -2.88 & 0.00 & 1 \\
\hline 35 & September 3, 2003 & 11:00:00 PM & 15.08 & 13.89 & 3.84 & -2.65 & 0.00 & 1 \\
\hline 36 & September 4, 2003 & $5: 26: 00$ AM & 15.09 & 13.89 & 3.84 & -2.64 & 0.00 & 5 \\
\hline 37 & September 4, 2003 & 5:46:00 AM & 15.09 & 13.89 & 3.84 & -2.64 & 0.00 & 1 \\
\hline 38 & September 4, 2003 & 5:48:00 AM & 15.09 & 13.89 & 3.84 & -2.64 & 0.00 & 1 \\
\hline 39 & October 14, 2003 & $6: 30: 00 \mathrm{AM}$ & 14.84 & 13.85 & 3.57 & -2.58 & 0.00 & 5 \\
\hline 40 & September 11, 2003 & 1:12:00 AM & 16.11 & 13.90 & 4.68 & -2.47 & 0.00 & 5 \\
\hline 41 & November 13, 2003 & 5:00:00 AM & 15.82 & 13.89 & 4.37 & -2.44 & 0.00 & 1 \\
\hline 42 & April 23, 2003 & $6: 10: 00 \mathrm{AM}$ & 13.66 & 14.03 & 2.05 & -2.42 & 0.00 & 5 \\
\hline 43 & September 11, 2003 & 8:00:00 PM & 13.89 & 13.80 & 2.48 & -2.39 & 0.00 & 5 \\
\hline 44 & October 14, 2003 & $6: 52: 00 \mathrm{AM}$ & 15.08 & 13.85 & 3.57 & -2.34 & 0.00 & 5 \\
\hline 45 & March 13, 2003 & $6: 50: 00 \mathrm{AM}$ & 13.35 & 13.64 & 1.99 & -2.28 & 0.00 & 5 \\
\hline 46 & February 13, 2003 & 3:54:00 PM & 13.68 & 13.73 & 2.21 & -2.26 & 0.00 & 1 \\
\hline 47 & November 10, 2003 & 4:44:00 AM & 13.65 & 13.52 & 2.32 & -2.19 & 0.00 & 5 \\
\hline 48 & July 23, 2003 & 5:22:00 AM & 13.88 & 14.37 & 1.67 & -2.16 & 0.00 & 5 \\
\hline 49 & April 14, 2003 & $6: 12: 00 \mathrm{AM}$ & 14.14 & 13.61 & 2.66 & -2.13 & 0.00 & 5 \\
\hline 50 & September 2, 2003 & 4:10:00 AM & 16.97 & 14.13 & 4.96 & -2.12 & 0.00 & 2 \\
\hline 51 & July 15, 2003 & 5:50:00 AM & 15.08 & 13.90 & 3.26 & -2.08 & 0.00 & 5 \\
\hline 52 & July 15, 2003 & 5:54:00 AM & 15.08 & 13.90 & 3.26 & -2.08 & 0.00 & 5 \\
\hline 53 & July 15, 2003 & 6:02:00 AM & 15.08 & 13.90 & 3.26 & -2.08 & 0.00 & 1 \\
\hline 54 & July 15, 2003 & 6:04:00 AM & 15.13 & 13.90 & 3.26 & -2.03 & 0.00 & 1 \\
\hline 55 & December 15, 2003 & 5:46:00 PM & 12.46 & 13.29 & 1.19 & -2.02 & 0.00 & 5 \\
\hline 56 & April 30, 2003 & $5: 14: 00$ AM & 14.17 & 13.82 & 2.36 & -2.01 & 0.00 & 5 \\
\hline 57 & November 17, 2003 & 6:06:00 AM & 15.82 & 13.74 & 4.08 & -2.00 & 0.00 & 5 \\
\hline 58 & September 8, 2003 & 7:56:00 AM & 15.33 & 13.96 & 3.35 & -1.98 & 0.00 & 5 \\
\hline 59 & April 15, 2003 & 5:56:00 AM & 13.66 & 14.38 & 1.26 & -1.98 & 0.00 & 5 \\
\hline 60 & September 25, 2003 & $3: 22: 00 \mathrm{AM}$ & 14.61 & 14.00 & 2.59 & -1.98 & 0.00 & 5 \\
\hline 61 & June 20,2003 & 6:00:00 AM & 14.61 & 13.99 & 2.58 & -1.96 & 0.00 & 5 \\
\hline 62 & June 20,2003 & $6: 10: 00 \mathrm{AM}$ & 14.61 & 13.99 & 2.58 & -1.96 & 0.00 & 5 \\
\hline 63 & June 20, 2003 & $6: 12: 00 \mathrm{AM}$ & 14.61 & 13.99 & 2.58 & -1.96 & 0.00 & 5 \\
\hline 64 & September 23, 2003 & $3: 44: 00$ AM & 15.33 & 14.07 & 3.22 & -1.96 & 0.00 & 5 \\
\hline 65 & September 23, 2003 & $3: 48: 00$ AM & 15.33 & 14.07 & 3.22 & -1.96 & 0.00 & 1 \\
\hline 66 & May 15, 2003 & $6: 24: 00 \mathrm{AM}$ & 14.61 & 13.90 & 2.66 & -1.95 & 0.00 & 5 \\
\hline
\end{tabular}




\begin{tabular}{|c|c|c|c|c|c|c|c|c|}
\hline $\begin{array}{l}\text { Record } \\
\text { Number }\end{array}$ & Date of Shipment & $\begin{array}{l}\text { Time of } \\
\text { Shipment }\end{array}$ & $\begin{array}{l}\text { Gross } \\
\text { Value }\end{array}$ & $\begin{array}{l}\text { Background } \\
\text { Measurement }\end{array}$ & $\begin{array}{l}\text { Standard } \\
\text { Deviation }\end{array}$ & Net Exposure & $\begin{array}{l}\text { Adjusted } \\
\text { Net } \\
\text { Exposure } \\
\end{array}$ & $\begin{array}{c}\text { Route } \\
\text { Number }\end{array}$ \\
\hline 67 & April 23, 2003 & 6:04:00 AM & 14.17 & 14.03 & 2.05 & -1.91 & 0.00 & 5 \\
\hline 68 & July 23, 2003 & $5: 42: 00 \mathrm{AM}$ & 14.15 & 14.37 & 1.67 & -1.89 & 0.00 & 5 \\
\hline 69 & September 28, 2003 & 9:56:00 PM & 14.60 & 13.97 & 2.51 & -1.88 & 0.00 & 1 \\
\hline 70 & July 15,2003 & 6:00:00 AM & 15.32 & 13.90 & 3.26 & -1.84 & 0.00 & 1 \\
\hline 71 & April 30, 2003 & 7:00:00 AM & 14.38 & 13.82 & 2.36 & -1.80 & 0.00 & 5 \\
\hline 72 & April 23, 2003 & 6:02:00 AM & 14.35 & 14.03 & 2.05 & -1.73 & 0.00 & 5 \\
\hline 73 & April 23, 2003 & $6: 12: 00$ AM & 14.35 & 14.03 & 2.05 & -1.73 & 0.00 & 5 \\
\hline 74 & April 14, 2003 & 6:14:00 AM & 14.55 & 13.61 & 2.66 & -1.72 & 0.00 & 5 \\
\hline 75 & April 23, 2003 & 6:00:00 AM & 14.38 & 14.03 & 2.05 & -1.70 & 0.00 & 5 \\
\hline 76 & August 25, 2003 & 5:58:00 PM & 14.15 & 13.84 & 2.00 & -1.69 & 0.00 & 1 \\
\hline 77 & September 28, 2003 & 9:54:00 PM & 14.84 & 13.97 & 2.51 & -1.64 & 0.00 & 1 \\
\hline 78 & December 18, 2003 & $6: 04: 00 \mathrm{AM}$ & 12.95 & 13.40 & 1.18 & -1.63 & 0.00 & 5 \\
\hline 79 & March 12, 2003 & $6: 20: 00 \mathrm{AM}$ & 13.58 & 13.77 & 1.40 & -1.59 & 0.00 & 5 \\
\hline 80 & April 29, 2003 & 9:04:00 PM & 14.61 & 13.82 & 2.36 & -1.57 & 0.00 & 1 \\
\hline 81 & April 29, 2003 & 9:18:00 PM & 14.61 & 13.82 & 2.36 & -1.57 & 0.00 & 1 \\
\hline 82 & June 20, 2003 & 5:26:00 AM & 15.03 & 13.99 & 2.58 & -1.54 & 0.00 & 5 \\
\hline 83 & November 10, 2003 & 4:46:00 AM & 14.31 & 13.52 & 2.32 & -1.53 & 0.00 & 5 \\
\hline 84 & July 22, 2003 & 6:06:00 AM & 13.88 & 13.91 & 1.49 & -1.52 & 0.00 & 1 \\
\hline 85 & June 19, 2003 & 10:00:00 PM & 15.08 & 13.99 & 2.58 & -1.49 & 0.00 & 1 \\
\hline 86 & June 19, 2003 & 11:02:00 PM & 15.08 & 13.99 & 2.58 & -1.49 & 0.00 & 1 \\
\hline 87 & June 20, 2003 & 1:28:00 AM & 15.08 & 13.99 & 2.58 & -1.49 & 0.00 & 1 \\
\hline 88 & March 11, 2003 & 8:56:00 PM & 13.68 & 13.77 & 1.40 & -1.49 & 0.00 & 1 \\
\hline 89 & March 12, 2003 & 6:16:00 AM & 13.68 & 13.77 & 1.40 & -1.49 & 0.00 & 5 \\
\hline 90 & February 23, 2003 & 2:00:00 PM & 14.30 & 13.83 & 1.96 & -1.48 & 0.00 & 2 \\
\hline 91 & September 28, 2003 & 9:02:00 PM & 15.03 & 13.97 & 2.51 & -1.45 & 0.00 & 1 \\
\hline 92 & June 9,2003 & 5:48:00 AM & 14.61 & 14.03 & 2.03 & -1.45 & 0.00 & 5 \\
\hline 93 & September 21, 2003 & 8:04:00 PM & 14.36 & 13.84 & 1.96 & -1.44 & 0.00 & 1 \\
\hline 94 & May 4, 2003 & 9:30:00 PM & 13.89 & 13.70 & 1.60 & -1.41 & 0.00 & 1 \\
\hline 95 & September 16, 2003 & 5:52:00 PM & 13.91 & 13.96 & 1.35 & -1.40 & 0.00 & 5 \\
\hline 96 & April 29, 2003 & 10:44:00 PM & 14.79 & 13.82 & 2.36 & -1.39 & 0.00 & 1 \\
\hline 97 & April 29, 2003 & 10:54:00 PM & 14.79 & 13.82 & 2.36 & -1.39 & 0.00 & 1 \\
\hline 98 & June 30, 2003 & 10:40:00 PM & 13.57 & 13.65 & 1.28 & -1.36 & 0.00 & 1 \\
\hline 99 & September 28, 2003 & 9:42:00 PM & 15.13 & 13.97 & 2.51 & -1.35 & 0.00 & 1 \\
\hline
\end{tabular}




\begin{tabular}{|c|c|c|c|c|c|c|c|c|}
\hline $\begin{array}{l}\text { Record } \\
\text { Number }\end{array}$ & Date of Shipment & $\begin{array}{l}\text { Time of } \\
\text { Shipment }\end{array}$ & $\begin{array}{l}\text { Gross } \\
\text { Value }\end{array}$ & $\begin{array}{l}\text { Background } \\
\text { Measurement }\end{array}$ & $\begin{array}{l}\text { Standard } \\
\text { Deviation }\end{array}$ & Net Exposure & $\begin{array}{l}\text { Adjusted } \\
\text { Net } \\
\text { Exposure } \\
\end{array}$ & $\begin{array}{c}\text { Route } \\
\text { Number }\end{array}$ \\
\hline 100 & August 10, 2003 & 6:58:00 PM & 13.91 & 13.75 & 1.51 & -1.34 & 0.00 & 1 \\
\hline 101 & December 2, 2003 & 7:04:00 PM & 13.42 & 13.47 & 1.29 & -1.34 & 0.00 & 5 \\
\hline 102 & July 22, 2003 & 5:56:00 AM & 14.06 & 13.91 & 1.49 & -1.34 & 0.00 & 1 \\
\hline 103 & July 22, 2003 & 6:02:00 AM & 14.06 & 13.91 & 1.49 & -1.34 & 0.00 & 1 \\
\hline 104 & April 29, 2003 & 10:58:00 PM & 14.85 & 13.82 & 2.36 & -1.33 & 0.00 & 1 \\
\hline 105 & April 8, 2003 & 9:12:00 PM & 13.92 & 13.66 & 1.59 & -1.33 & 0.00 & 1 \\
\hline 106 & October 9, 2003 & $7: 12: 00$ AM & 14.13 & 13.89 & 1.54 & -1.30 & 0.00 & 5 \\
\hline 107 & October 9, 2003 & 7:14:00 AM & 14.13 & 13.89 & 1.54 & -1.30 & 0.00 & 5 \\
\hline 108 & August 19, 2003 & 4:10:00 AM & 13.89 & 13.86 & 1.31 & -1.28 & 0.00 & 1 \\
\hline 109 & August 19, 2003 & 5:38:00 AM & 13.89 & 13.86 & 1.31 & -1.28 & 0.00 & 1 \\
\hline 110 & October 8, 2003 & $6: 22: 00 \mathrm{AM}$ & 14.37 & 13.88 & 1.72 & -1.23 & 0.00 & 5 \\
\hline 111 & July 22,2003 & 5:08:00 PM & 14.12 & 14.07 & 1.26 & -1.21 & 0.00 & 5 \\
\hline 112 & June 9, 2003 & 6:02:00 AM & 14.85 & 14.03 & 2.03 & -1.21 & 0.00 & 5 \\
\hline 113 & September 11, 2003 & 8:02:00 PM & 15.08 & 13.80 & 2.48 & -1.20 & 0.00 & 5 \\
\hline 114 & March 16, 2003 & 7:46:00 PM & 14.41 & 13.77 & 1.83 & -1.20 & 0.00 & 5 \\
\hline 115 & September 16, 2003 & 7:34:00 PM & 14.12 & 13.96 & 1.35 & -1.19 & 0.00 & 1 \\
\hline 116 & May 4, 2003 & 9:28:00 PM & 14.13 & 13.70 & 1.60 & -1.17 & 0.00 & 2 \\
\hline 117 & December 18, 2003 & 6:06:00 AM & 13.42 & 13.40 & 1.18 & -1.16 & 0.00 & 5 \\
\hline 118 & September 28, 2003 & 10:04:00 PM & 15.32 & 13.97 & 2.51 & -1.16 & 0.00 & 1 \\
\hline 119 & June 30,2003 & 7:06:00 PM & 13.88 & 13.80 & 1.23 & -1.15 & 0.00 & 5 \\
\hline 120 & July 12, 2003 & 4:38:00 PM & 14.12 & 13.97 & 1.29 & -1.14 & 0.00 & 1 \\
\hline 121 & September 23, 2003 & 2:20:00 PM & 14.60 & 13.99 & 1.74 & -1.13 & 0.00 & 1 \\
\hline 122 & August 20, 2003 & 7:24:00 AM & 15.09 & 14.48 & 1.73 & -1.12 & 0.00 & 5 \\
\hline 123 & April 9, 2003 & $6: 26: 00 \mathrm{AM}$ & 14.14 & 13.66 & 1.59 & -1.11 & 0.00 & 5 \\
\hline 124 & May 21, 2003 & 7:06:00 PM & 14.08 & 13.84 & 1.35 & -1.11 & 0.00 & 5 \\
\hline 125 & June 8, 2003 & 5:48:00 PM & 14.15 & 14.01 & 1.24 & -1.10 & 0.00 & 5 \\
\hline 126 & May 22, 2003 & 6:18:00 AM & 14.37 & 13.72 & 1.75 & -1.10 & 0.00 & 5 \\
\hline 127 & May 22, 2003 & 6:30:00 AM & 14.37 & 13.72 & 1.75 & -1.10 & 0.00 & 5 \\
\hline 128 & May 11, 2003 & 11:42:00 PM & 14.41 & 13.67 & 1.84 & -1.10 & 0.00 & 2 \\
\hline 129 & May 20,2003 & 6:04:00 AM & 14.13 & 13.72 & 1.50 & -1.09 & 0.00 & 5 \\
\hline 130 & December 2, 2003 & 3:00:00 PM & 13.67 & 13.47 & 1.29 & -1.09 & 0.00 & 1 \\
\hline 131 & May 13,2003 & $6: 00: 00 \mathrm{AM}$ & 13.89 & 13.67 & 1.31 & -1.09 & 0.00 & 5 \\
\hline 132 & May 13,2003 & 6:04:00 AM & 13.89 & 13.67 & 1.31 & -1.09 & 0.00 & 5 \\
\hline
\end{tabular}




\begin{tabular}{|c|c|c|c|c|c|c|c|c|}
\hline $\begin{array}{l}\text { Record } \\
\text { Number }\end{array}$ & Date of Shipment & $\begin{array}{l}\text { Time of } \\
\text { Shipment }\end{array}$ & $\begin{array}{l}\text { Gross } \\
\text { Value }\end{array}$ & $\begin{array}{l}\text { Background } \\
\text { Measurement }\end{array}$ & $\begin{array}{l}\text { Standard } \\
\text { Deviation }\end{array}$ & Net Exposure & $\begin{array}{l}\text { Adjusted } \\
\text { Net } \\
\text { Exposure } \\
\end{array}$ & $\begin{array}{c}\text { Route } \\
\text { Number }\end{array}$ \\
\hline 133 & October 9, 2003 & $7: 16: 00$ AM & 14.37 & 13.89 & 1.54 & -1.06 & 0.00 & 5 \\
\hline 134 & August 17, 2003 & 1:14:00 PM & 14.15 & 13.90 & 1.29 & -1.05 & 0.00 & 1 \\
\hline 135 & December 15, 2003 & 7:26:00 PM & 13.44 & 13.29 & 1.19 & -1.04 & 0.00 & 5 \\
\hline 136 & October 23, 2003 & 7:56:00 AM & 14.13 & 13.75 & 1.42 & -1.04 & 0.00 & 1 \\
\hline 137 & September 21, 2003 & 8:12:00 PM & 14.78 & 13.84 & 1.96 & -1.02 & 0.00 & 1 \\
\hline 138 & July 27,2003 & 10:30:00 PM & 13.88 & 13.77 & 1.13 & -1.02 & 0.00 & 1 \\
\hline 139 & April 20, 2003 & 8:36:00 PM & 14.16 & 13.88 & 1.29 & -1.01 & 0.00 & 1 \\
\hline 140 & July 14,2003 & 6:00:00 PM & 14.36 & 13.96 & 1.40 & -1.00 & 0.00 & 6 \\
\hline 141 & July 14, 2003 & 7:20:00 AM & 13.88 & 13.75 & 1.13 & -1.00 & 0.00 & 5 \\
\hline 142 & June 22, 2003 & 7:18:00 PM & 14.12 & 13.83 & 1.28 & -0.99 & 0.00 & 1 \\
\hline 143 & June 9, 2003 & $12: 42: 00$ AM & 15.08 & 14.03 & 2.03 & -0.98 & 0.00 & 1 \\
\hline 144 & May 21, 2003 & 4:34:00 AM & 14.13 & 13.73 & 1.37 & -0.97 & 0.00 & 5 \\
\hline 145 & September 21, 2003 & 8:06:00 PM & 14.83 & 13.84 & 1.96 & -0.97 & 0.00 & 1 \\
\hline 146 & May 8, 2003 & 5:00:00 AM & 14.14 & 13.83 & 1.28 & -0.97 & 0.00 & 6 \\
\hline 147 & June 9, 2003 & $6: 06: 00 \mathrm{AM}$ & 15.09 & 14.03 & 2.03 & -0.97 & 0.00 & 5 \\
\hline 148 & June 9, 2003 & $6: 42: 00 \mathrm{AM}$ & 15.09 & 14.03 & 2.03 & -0.97 & 0.00 & 1 \\
\hline 149 & March 20, 2003 & 7:04:00 PM & 13.89 & 13.71 & 1.14 & -0.96 & 0.00 & 1 \\
\hline 150 & August 12, 2003 & 6:04:00 AM & 13.88 & 13.73 & 1.11 & -0.96 & 0.00 & 1 \\
\hline 151 & August 12, 2003 & $6: 16: 00 \mathrm{AM}$ & 13.88 & 13.73 & 1.11 & -0.96 & 0.00 & 1 \\
\hline 152 & July 23,2003 & 5:36:00 AM & 15.08 & 14.37 & 1.67 & -0.96 & 0.00 & 5 \\
\hline 153 & July 20, 2003 & 6:58:00 PM & 14.15 & 13.86 & 1.25 & -0.95 & 0.00 & 1 \\
\hline 154 & June 19, 2003 & 10:58:00 PM & 15.62 & 13.99 & 2.58 & -0.95 & 0.00 & 5 \\
\hline 155 & September 22, 2003 & $6: 44: 00$ AM & 14.85 & 13.84 & 1.96 & -0.95 & 0.00 & 5 \\
\hline 156 & September 22, 2003 & $6: 50: 00 \mathrm{AM}$ & 14.85 & 13.84 & 1.96 & -0.95 & 0.00 & 5 \\
\hline 157 & September 22, 2003 & 7:30:00 AM & 14.85 & 13.84 & 1.96 & -0.95 & 0.00 & 6 \\
\hline 158 & April 2, 2003 & 5:18:00 AM & 14.38 & 13.87 & 1.46 & -0.95 & 0.00 & 1 \\
\hline 159 & April 2, 2003 & $5: 48: 00$ AM & 14.38 & 13.87 & 1.46 & -0.95 & 0.00 & 5 \\
\hline 160 & May 5, 2003 & $6: 14: 00 \mathrm{AM}$ & 14.37 & 13.70 & 1.60 & -0.93 & 0.00 & 5 \\
\hline 161 & May 5, 2003 & $6: 18: 00 \mathrm{AM}$ & 14.37 & 13.70 & 1.60 & -0.93 & 0.00 & 5 \\
\hline 162 & May 15,2003 & 4:52:00 AM & 15.63 & 13.90 & 2.66 & -0.93 & 0.00 & 1 \\
\hline 163 & April 18, 2003 & 5:58:00 AM & 13.90 & 13.70 & 1.13 & -0.93 & 0.00 & 5 \\
\hline 164 & September 14, 2003 & 6:26:00 PM & 14.36 & 13.77 & 1.52 & -0.93 & 0.00 & 1 \\
\hline 165 & August 11, 2003 & 4:00:00 PM & 14.15 & 13.85 & 1.23 & -0.92 & 0.00 & 1 \\
\hline
\end{tabular}




\begin{tabular}{|c|c|c|c|c|c|c|c|c|}
\hline $\begin{array}{l}\text { Record } \\
\text { Number }\end{array}$ & Date of Shipment & $\begin{array}{l}\text { Time of } \\
\text { Shipment }\end{array}$ & $\begin{array}{l}\text { Gross } \\
\text { Value }\end{array}$ & $\begin{array}{l}\text { Background } \\
\text { Measurement }\end{array}$ & $\begin{array}{l}\text { Standard } \\
\text { Deviation }\end{array}$ & Net Exposure & $\begin{array}{l}\text { Adjusted } \\
\text { Net } \\
\text { Exposure } \\
\end{array}$ & $\begin{array}{c}\text { Route } \\
\text { Number }\end{array}$ \\
\hline 166 & December 10, 2003 & $3: 32: 00 \mathrm{AM}$ & 13.86 & 13.52 & 1.26 & -0.92 & 0.00 & 1 \\
\hline 167 & December 18, 2003 & 5:14:00 AM & 13.66 & 13.40 & 1.18 & -0.92 & 0.00 & 5 \\
\hline 168 & September 28, 2003 & 9:48:00 PM & 15.56 & 13.97 & 2.51 & -0.92 & 0.00 & 1 \\
\hline 169 & September 29, 2003 & $2: 54: 00$ AM & 15.56 & 13.97 & 2.51 & -0.92 & 0.00 & 1 \\
\hline 170 & April 8, 2003 & 9:08:00 PM & 14.34 & 13.66 & 1.59 & -0.91 & 0.00 & 1 \\
\hline 171 & April 8, 2003 & 9:10:00 PM & 14.34 & 13.66 & 1.59 & -0.91 & 0.00 & 1 \\
\hline 172 & December 18, 2003 & 4:42:00 AM & 13.68 & 13.40 & 1.18 & -0.90 & 0.00 & 5 \\
\hline 173 & June 8, 2003 & 3:58:00 PM & 14.36 & 14.01 & 1.24 & -0.89 & 0.00 & 5 \\
\hline 174 & April 14, 2003 & 6:10:00 AM & 15.39 & 13.61 & 2.66 & -0.88 & 0.00 & 1 \\
\hline 175 & April 14, 2003 & $6: 16: 00 \mathrm{AM}$ & 15.39 & 13.61 & 2.66 & -0.88 & 0.00 & 5 \\
\hline 176 & July 1, 2003 & 7:00:00 PM & 14.12 & 13.80 & 1.19 & -0.87 & 0.00 & 5 \\
\hline 177 & September 7, 2003 & 10:16:00 PM & 14.12 & 13.82 & 1.16 & -0.87 & 0.00 & 1 \\
\hline 178 & September 7, 2003 & 10:20:00 PM & 14.12 & 13.82 & 1.16 & -0.87 & 0.00 & 1 \\
\hline 179 & March 5, 2003 & 9:38:00 PM & 13.90 & 13.53 & 1.23 & -0.86 & 0.00 & 1 \\
\hline 180 & July 21, 2003 & 9:24:00 PM & 14.54 & 13.91 & 1.49 & -0.86 & 0.00 & 1 \\
\hline 181 & April 10, 2003 & 5:08:00 AM & 14.14 & 13.73 & 1.27 & -0.86 & 0.00 & 5 \\
\hline 182 & May 21, 2003 & 6:58:00 PM & 14.33 & 13.84 & 1.35 & -0.86 & 0.00 & 5 \\
\hline 183 & April 16, 2003 & 3:30:00 AM & 13.90 & 13.55 & 1.18 & -0.83 & 0.00 & 1 \\
\hline 184 & May 16, 2003 & $6: 16: 00 \mathrm{AM}$ & 14.13 & 13.68 & 1.28 & -0.83 & 0.00 & 5 \\
\hline 185 & July 21, 2003 & 8:36:00 AM & 14.36 & 13.96 & 1.22 & -0.83 & 0.00 & 1 \\
\hline 186 & December 15, 2003 & 5:46:00 AM & 13.69 & 13.39 & 1.12 & -0.82 & 0.00 & 5 \\
\hline 187 & May 19, 2003 & 5:46:00 AM & 13.89 & 13.65 & 1.06 & -0.82 & 0.00 & 5 \\
\hline 188 & August 19, 2003 & 6:04:00 AM & 14.36 & 13.86 & 1.31 & -0.81 & 0.00 & 1 \\
\hline 189 & November 17, 2003 & 6:00:00 AM & 17.01 & 13.74 & 4.08 & -0.81 & 0.00 & 5 \\
\hline 190 & April 21, 2003 & 5:58:00 AM & 14.37 & 13.88 & 1.29 & -0.80 & 0.00 & 5 \\
\hline 191 & October 23, 2003 & 8:02:00 AM & 14.37 & 13.75 & 1.42 & -0.80 & 0.00 & 1 \\
\hline 192 & May 16, 2003 & $6: 10: 00$ AM & 14.16 & 13.68 & 1.28 & -0.80 & 0.00 & 5 \\
\hline 193 & July 11, 2003 & $11: 24: 00 \mathrm{AM}$ & 14.36 & 13.96 & 1.19 & -0.79 & 0.00 & 1 \\
\hline 194 & August 11, 2003 & 7:36:00 AM & 14.12 & 13.69 & 1.22 & -0.78 & 0.00 & 5 \\
\hline 195 & October 9, 2003 & 7:10:00 AM & 14.65 & 13.89 & 1.54 & -0.78 & 0.00 & 1 \\
\hline 196 & August 21, 2003 & 5:44:00 AM & 14.85 & 13.63 & 1.99 & -0.77 & 0.00 & 5 \\
\hline 197 & August 21, 2003 & $6: 10: 00 \mathrm{AM}$ & 14.85 & 13.63 & 1.99 & -0.77 & 0.00 & 1 \\
\hline 198 & September 11, 2003 & 8:08:00 PM & 15.51 & 13.80 & 2.48 & -0.77 & 0.00 & 1 \\
\hline
\end{tabular}




\begin{tabular}{|c|c|c|c|c|c|c|c|c|}
\hline $\begin{array}{l}\text { Record } \\
\text { Number }\end{array}$ & Date of Shipment & $\begin{array}{l}\text { Time of } \\
\text { Shipment }\end{array}$ & $\begin{array}{l}\text { Gross } \\
\text { Value }\end{array}$ & $\begin{array}{l}\text { Background } \\
\text { Measurement }\end{array}$ & $\begin{array}{l}\text { Standard } \\
\text { Deviation }\end{array}$ & Net Exposure & $\begin{array}{l}\text { Adjusted } \\
\text { Net } \\
\text { Exposure } \\
\end{array}$ & $\begin{array}{c}\text { Route } \\
\text { Number }\end{array}$ \\
\hline 199 & August 19, 2003 & $5: 40: 00 \mathrm{AM}$ & 14.40 & 13.86 & 1.31 & -0.77 & 0.00 & 1 \\
\hline 200 & November 6, 2003 & 4:46:00 AM & 13.90 & 13.45 & 1.22 & -0.77 & 0.00 & 5 \\
\hline 201 & April 28, 2003 & 4:14:00 AM & 14.07 & 13.68 & 1.15 & -0.76 & 0.00 & 1 \\
\hline 202 & August 10, 2003 & 9:00:00 PM & 14.15 & 13.69 & 1.22 & -0.75 & 0.00 & 1 \\
\hline 203 & May 5, 2003 & $6: 20: 00$ AM & 14.55 & 13.70 & 1.60 & -0.75 & 0.00 & 5 \\
\hline 204 & April 17, 2003 & $6: 12: 00$ AM & 14.14 & 13.68 & 1.20 & -0.75 & 0.00 & 5 \\
\hline 205 & April 17, 2003 & 6:22:00 AM & 14.14 & 13.68 & 1.20 & -0.75 & 0.00 & 5 \\
\hline 206 & November 11, 2003 & 5:26:00 PM & 13.84 & 13.46 & 1.12 & -0.74 & 0.00 & 5 \\
\hline 207 & June 8, 2003 & 9:02:00 PM & 15.32 & 14.03 & 2.03 & -0.74 & 0.00 & 6 \\
\hline 208 & June 9, 2003 & 6:30:00 AM & 15.32 & 14.03 & 2.03 & -0.74 & 0.00 & 1 \\
\hline 209 & May 26, 2003 & 8:20:00 PM & 14.36 & 13.81 & 1.28 & -0.73 & 0.00 & 1 \\
\hline 210 & March 13, 2003 & $6: 54: 00 \mathrm{AM}$ & 14.90 & 13.64 & 1.99 & -0.73 & 0.00 & 5 \\
\hline 211 & April 24, 2003 & 4:48:00 AM & 14.14 & 13.70 & 1.17 & -0.73 & 0.00 & 5 \\
\hline 212 & May 1, 2003 & 7:44:00 AM & 14.37 & 13.72 & 1.37 & -0.72 & 0.00 & 1 \\
\hline 213 & August 12, 2003 & $6: 24: 00 \mathrm{AM}$ & 14.12 & 13.73 & 1.11 & -0.72 & 0.00 & 1 \\
\hline 214 & April 2, 2003 & $5: 22: 00 \mathrm{AM}$ & 14.61 & 13.87 & 1.46 & -0.72 & 0.00 & 1 \\
\hline 215 & May 1, 2003 & 6:16:00 AM & 14.38 & 13.72 & 1.37 & -0.71 & 0.00 & 5 \\
\hline 216 & July 7, 2003 & 5:34:00 PM & 14.64 & 13.98 & 1.37 & -0.71 & 0.00 & 5 \\
\hline 217 & September 22, 2003 & $6: 40: 00 \mathrm{AM}$ & 15.09 & 13.84 & 1.96 & -0.71 & 0.00 & 5 \\
\hline 218 & May 15, 2003 & 5:30:00 PM & 14.36 & 13.81 & 1.25 & -0.70 & 0.00 & 5 \\
\hline 219 & May 8, 2003 & $12: 22: 00 \mathrm{AM}$ & 14.41 & 13.83 & 1.28 & -0.70 & 0.00 & 1 \\
\hline 220 & July 10, 2003 & 6:36:00 PM & 14.36 & 13.91 & 1.15 & -0.70 & 0.00 & 1 \\
\hline 221 & May 21, 2003 & 5:14:00 AM & 14.41 & 13.73 & 1.37 & -0.69 & 0.00 & 5 \\
\hline 222 & July 22, 2003 & 5:06:00 PM & 14.64 & 14.07 & 1.26 & -0.69 & 0.00 & 5 \\
\hline 223 & December 18, 2003 & $3: 44: 00$ AM & 13.90 & 13.40 & 1.18 & -0.68 & 0.00 & 1 \\
\hline 224 & September 21, 2003 & 5:44:00 PM & 14.30 & 13.90 & 1.07 & -0.67 & 0.00 & 1 \\
\hline 225 & May 18, 2003 & 6:24:00 PM & 14.33 & 13.80 & 1.20 & -0.67 & 0.00 & 5 \\
\hline 226 & April 16, 2003 & 6:08:00 AM & 14.07 & 13.55 & 1.18 & -0.66 & 0.00 & 5 \\
\hline 227 & September 19, 2003 & $10: 54: 00$ AM & 14.33 & 13.78 & 1.21 & -0.66 & 0.00 & 2 \\
\hline 228 & April 2, 2003 & 8:08:00 PM & 14.38 & 13.68 & 1.36 & -0.66 & 0.00 & 5 \\
\hline 229 & October 29, 2003 & 6:00:00 AM & 14.13 & 13.54 & 1.24 & -0.65 & 0.00 & 5 \\
\hline 230 & September 23, 2003 & 11:38:00 PM & 15.09 & 13.99 & 1.74 & -0.64 & 0.00 & 1 \\
\hline 231 & June 30, 2003 & 6:30:00 PM & 14.40 & 13.80 & 1.23 & -0.63 & 0.00 & 6 \\
\hline
\end{tabular}




\begin{tabular}{|c|c|c|c|c|c|c|c|c|}
\hline $\begin{array}{l}\text { Record } \\
\text { Number }\end{array}$ & Date of Shipment & $\begin{array}{l}\text { Time of } \\
\text { Shipment }\end{array}$ & $\begin{array}{l}\text { Gross } \\
\text { Value }\end{array}$ & $\begin{array}{l}\text { Background } \\
\text { Measurement }\end{array}$ & $\begin{array}{l}\text { Standard } \\
\text { Deviation }\end{array}$ & Net Exposure & $\begin{array}{l}\text { Adjusted } \\
\text { Net } \\
\text { Exposure } \\
\end{array}$ & $\begin{array}{c}\text { Route } \\
\text { Number }\end{array}$ \\
\hline 232 & June 30, 2003 & 7:02:00 PM & 14.40 & 13.80 & 1.23 & -0.63 & 0.00 & 5 \\
\hline 233 & September 19, 2003 & 10:48:00 AM & 14.36 & 13.78 & 1.21 & -0.63 & 0.00 & 2 \\
\hline 234 & April 7, 2003 & 6:14:00 AM & 14.07 & 13.53 & 1.17 & -0.63 & 0.00 & 5 \\
\hline 235 & November 17, 2003 & 9:00:00 PM & 13.83 & 13.24 & 1.21 & -0.62 & 0.00 & 5 \\
\hline 236 & July 22,2003 & $6: 52: 00$ AM & 14.78 & 13.91 & 1.49 & -0.62 & 0.00 & 1 \\
\hline 237 & April 10, 2003 & 5:06:00 AM & 14.38 & 13.73 & 1.27 & -0.62 & 0.00 & 5 \\
\hline 238 & June 12, 2003 & 6:00:00 PM & 14.64 & 13.94 & 1.32 & -0.62 & 0.00 & 1 \\
\hline 239 & September 21, 2003 & 5:46:00 PM & 14.36 & 13.90 & 1.07 & -0.61 & 0.00 & 1 \\
\hline 240 & November 20, 2003 & 4:56:00 AM & 14.10 & 13.46 & 1.25 & -0.61 & 0.00 & 5 \\
\hline 241 & December 15, 2003 & 5:38:00 AM & 13.91 & 13.39 & 1.12 & -0.60 & 0.00 & 5 \\
\hline 242 & July 21,2003 & 9:28:00 PM & 14.82 & 13.91 & 1.49 & -0.58 & 0.00 & 1 \\
\hline 243 & October 7, 2003 & $6: 52: 00 \mathrm{AM}$ & 14.37 & 13.84 & 1.10 & -0.57 & 0.00 & 5 \\
\hline 244 & June 20, 2003 & $6: 50: 00 \mathrm{AM}$ & 16.00 & 13.99 & 2.58 & -0.57 & 0.00 & 5 \\
\hline 245 & September 28, 2003 & 3:50:00 PM & 14.64 & 13.99 & 1.21 & -0.56 & 0.00 & 1 \\
\hline 246 & April 21, 2003 & 7:30:00 AM & 14.61 & 13.88 & 1.29 & -0.56 & 0.00 & 1 \\
\hline 247 & April 21, 2003 & 7:34:00 AM & 14.61 & 13.88 & 1.29 & -0.56 & 0.00 & 1 \\
\hline 248 & April 16, 2003 & 6:06:00 AM & 14.17 & 13.55 & 1.18 & -0.56 & 0.00 & 5 \\
\hline 249 & July 22, 2003 & 6:04:00 AM & 14.84 & 13.91 & 1.49 & -0.56 & 0.00 & 1 \\
\hline 250 & April 16, 2003 & 8:16:00 AM & 14.38 & 13.65 & 1.29 & -0.56 & 0.00 & 1 \\
\hline 251 & April 7, 2003 & $6: 10: 00 \mathrm{AM}$ & 14.14 & 13.53 & 1.17 & -0.56 & 0.00 & 5 \\
\hline 252 & May 8, 2003 & $5: 44: 00 \mathrm{AM}$ & 14.56 & 13.83 & 1.28 & -0.55 & 0.00 & 5 \\
\hline 253 & May 16, 2003 & $6: 14: 00 \mathrm{AM}$ & 14.41 & 13.68 & 1.28 & -0.55 & 0.00 & 5 \\
\hline 254 & May 15, 2003 & $6: 26: 00 \mathrm{AM}$ & 16.01 & 13.90 & 2.66 & -0.55 & 0.00 & 1 \\
\hline 255 & April 30, 2003 & 7:02:00 AM & 15.64 & 13.82 & 2.36 & -0.54 & 0.00 & 5 \\
\hline 256 & June 1, 2003 & 6:44:00 PM & 14.33 & 13.70 & 1.15 & -0.52 & 0.00 & 5 \\
\hline 257 & August 24, 2003 & 7:44:00 PM & 14.33 & 13.73 & 1.12 & -0.52 & 0.00 & 5 \\
\hline 258 & October 8, 2003 & 1:00:00 AM & 15.09 & 13.88 & 1.72 & -0.51 & 0.00 & 1 \\
\hline 259 & August 27, 2003 & 7:30:00 AM & 14.61 & 13.60 & 1.52 & -0.51 & 0.00 & 5 \\
\hline 260 & April 17, 2003 & 5:54:00 AM & 14.38 & 13.68 & 1.20 & -0.51 & 0.00 & 5 \\
\hline 261 & April 17, 2003 & $6: 10: 00 \mathrm{AM}$ & 14.38 & 13.68 & 1.20 & -0.51 & 0.00 & 5 \\
\hline 262 & May 20, 2003 & 9:04:00 PM & 14.60 & 13.73 & 1.37 & -0.50 & 0.00 & 1 \\
\hline 263 & November 12, 2003 & 3:30:00 PM & 15.82 & 14.66 & 1.66 & -0.50 & 0.00 & 1 \\
\hline 264 & July 27,2003 & 8:00:00 PM & 14.40 & 13.77 & 1.13 & -0.50 & 0.00 & 1 \\
\hline
\end{tabular}




\begin{tabular}{|c|c|c|c|c|c|c|c|c|}
\hline $\begin{array}{l}\text { Record } \\
\text { Number }\end{array}$ & Date of Shipment & $\begin{array}{c}\text { Time of } \\
\text { Shipment }\end{array}$ & $\begin{array}{l}\text { Gross } \\
\text { Value }\end{array}$ & $\begin{array}{l}\text { Background } \\
\text { Measurement }\end{array}$ & $\begin{array}{l}\text { Standard } \\
\text { Deviation }\end{array}$ & Net Exposure & $\begin{array}{l}\text { Adjusted } \\
\text { Net } \\
\text { Exposure }\end{array}$ & $\begin{array}{c}\text { Route } \\
\text { Number }\end{array}$ \\
\hline 265 & May 26,2003 & 8:22:00 PM & 14.60 & 13.81 & 1.28 & -0.49 & 0.00 & 2 \\
\hline 266 & July 23, 2003 & 5:38:00 AM & 14.60 & 13.81 & 1.28 & -0.49 & 0.00 & 5 \\
\hline 267 & May 20, 2003 & 10:50:00 PM & 14.61 & 13.73 & 1.37 & -0.49 & 0.00 & 1 \\
\hline 268 & May 21, 2003 & 6:02:00 AM & 14.61 & 13.73 & 1.37 & -0.49 & 0.00 & 5 \\
\hline 269 & September 18, 2003 & 11:30:00 PM & 14.37 & 13.60 & 1.26 & -0.49 & 0.00 & 1 \\
\hline 270 & September 19, 2003 & 5:12:00 AM & 14.37 & 13.60 & 1.26 & -0.49 & 0.00 & 1 \\
\hline 271 & September 19, 2003 & 5:40:00 AM & 14.37 & 13.60 & 1.26 & -0.49 & 0.00 & 5 \\
\hline 272 & September 19, 2003 & $5: 52: 00 \mathrm{AM}$ & 14.37 & 13.60 & 1.26 & -0.49 & 0.00 & 5 \\
\hline 273 & September 19, 2003 & 5:54:00 AM & 14.37 & 13.60 & 1.26 & -0.49 & 0.00 & 5 \\
\hline 274 & September 19, 2003 & $6: 10: 00 \mathrm{AM}$ & 14.37 & 13.60 & 1.26 & -0.49 & 0.00 & 1 \\
\hline 275 & July 13,2003 & $10: 42: 00 \mathrm{PM}$ & 14.40 & 13.75 & 1.13 & -0.48 & 0.00 & 1 \\
\hline 276 & October 20, 2003 & $5: 30: 00$ AM & 14.13 & 13.57 & 1.04 & -0.48 & 0.00 & 5 \\
\hline 277 & October 20, 2003 & $5: 52: 00 \mathrm{AM}$ & 14.13 & 13.57 & 1.04 & -0.48 & 0.00 & 1 \\
\hline 278 & April 28, 2003 & 9:10:00 PM & 14.65 & 13.75 & 1.37 & -0.47 & 0.00 & 2 \\
\hline 279 & July 20, 2003 & 6:54:00 PM & 14.64 & 13.86 & 1.25 & -0.46 & 0.00 & 1 \\
\hline 280 & October 12, 2003 & 3:18:00 AM & 14.37 & 13.62 & 1.21 & -0.46 & 0.00 & 1 \\
\hline 281 & October 14, 2003 & 8:44:00 AM & 14.61 & 13.78 & 1.29 & -0.46 & 0.00 & 1 \\
\hline 282 & November 4, 2003 & 8:40:00 AM & 14.35 & 13.49 & 1.31 & -0.45 & 0.00 & 1 \\
\hline 283 & November 5, 2003 & 7:10:00 PM & 14.14 & 13.46 & 1.13 & -0.45 & 0.00 & 1 \\
\hline 284 & November 11, 2003 & 4:58:00 PM & 14.13 & 13.46 & 1.12 & -0.45 & 0.00 & 5 \\
\hline 285 & September 15, 2003 & 2:02:00 AM & 14.61 & 13.70 & 1.36 & -0.45 & 0.00 & 1 \\
\hline 286 & June 1, 2003 & 7:30:00 PM & 14.40 & 13.70 & 1.15 & -0.45 & 0.00 & 1 \\
\hline 287 & June 5, 2003 & $6: 00: 00 \mathrm{AM}$ & 14.61 & 13.84 & 1.22 & -0.44 & 0.00 & 6 \\
\hline 288 & September 14, 2003 & 8:50:00 AM & 14.85 & 13.77 & 1.52 & -0.44 & 0.00 & 1 \\
\hline 289 & May 20, 2003 & 6:06:00 AM & 14.79 & 13.72 & 1.50 & -0.43 & 0.00 & 5 \\
\hline 290 & October 28, 2003 & 4:30:00 PM & 14.60 & 13.73 & 1.30 & -0.43 & 0.00 & 1 \\
\hline 291 & June 23, 2003 & 10:42:00 PM & 14.61 & 13.77 & 1.27 & -0.43 & 0.00 & 1 \\
\hline 292 & June 24, 2003 & 6:48:00 AM & 14.61 & 13.77 & 1.27 & -0.43 & 0.00 & 5 \\
\hline 293 & June 3, 2003 & 6:06:00 AM & 14.84 & 13.94 & 1.33 & -0.43 & 0.00 & 2 \\
\hline 294 & April 2, 2003 & 5:24:00 AM & 14.90 & 13.87 & 1.46 & -0.43 & 0.00 & 1 \\
\hline 295 & July 23, 2003 & $6: 24: 00 \mathrm{AM}$ & 15.62 & 14.37 & 1.67 & -0.42 & 0.00 & 1 \\
\hline 296 & March 20, 2003 & 1:38:00 AM & 14.86 & 13.62 & 1.66 & -0.42 & 0.00 & 1 \\
\hline 297 & September 21, 2003 & 8:18:00 PM & 15.38 & 13.84 & 1.96 & -0.42 & 0.00 & 1 \\
\hline
\end{tabular}




\begin{tabular}{|c|c|c|c|c|c|c|c|c|}
\hline $\begin{array}{l}\text { Record } \\
\text { Number }\end{array}$ & Date of Shipment & $\begin{array}{l}\text { Time of } \\
\text { Shipment }\end{array}$ & $\begin{array}{l}\text { Gross } \\
\text { Value }\end{array}$ & $\begin{array}{l}\text { Background } \\
\text { Measurement }\end{array}$ & $\begin{array}{l}\text { Standard } \\
\text { Deviation }\end{array}$ & Net Exposure & $\begin{array}{l}\text { Adjusted } \\
\text { Net } \\
\text { Exposure }\end{array}$ & $\begin{array}{c}\text { Route } \\
\text { Number }\end{array}$ \\
\hline 298 & October 29, 2003 & 6:02:00 AM & 14.37 & 13.54 & 1.24 & -0.41 & 0.00 & 5 \\
\hline 299 & April 10, 2003 & 5:02:00 AM & 14.59 & 13.73 & 1.27 & -0.41 & 0.00 & 5 \\
\hline 300 & October 16, 2003 & 5:00:00 AM & 14.37 & 13.60 & 1.18 & -0.41 & 0.00 & 5 \\
\hline 301 & September 23, 2003 & 8:56:00 AM & 15.32 & 13.99 & 1.74 & -0.41 & 0.00 & 1 \\
\hline 302 & September 24, 2003 & 7:28:00 AM & 15.33 & 13.99 & 1.74 & -0.40 & 0.00 & 1 \\
\hline 303 & September 2, 2003 & 5:28:00 PM & 14.54 & 13.71 & 1.22 & -0.39 & 0.00 & 6 \\
\hline 304 & May 9, 2003 & 6:22:00 AM & 14.41 & 13.61 & 1.19 & -0.39 & 0.00 & 5 \\
\hline 305 & May 9, 2003 & 6:04:00 AM & 14.42 & 13.61 & 1.19 & -0.38 & 0.00 & 5 \\
\hline 306 & December 3, 2003 & 7:36:00 PM & 14.56 & 13.61 & 1.33 & -0.38 & 0.00 & 1 \\
\hline 307 & May 12,2003 & 10:04:00 PM & 14.61 & 13.67 & 1.31 & -0.37 & 0.00 & 1 \\
\hline 308 & May 12, 2003 & 10:10:00 PM & 14.61 & 13.67 & 1.31 & -0.37 & 0.00 & 1 \\
\hline 309 & May 13, 2003 & $11: 14: 00$ PM & 14.61 & 13.62 & 1.36 & -0.37 & 0.00 & 1 \\
\hline 310 & May 14,2003 & 6:32:00 AM & 14.61 & 13.62 & 1.36 & -0.37 & 0.00 & 5 \\
\hline 311 & September 28, 2003 & 4:32:00 PM & 14.84 & 13.99 & 1.21 & -0.36 & 0.00 & 1 \\
\hline 312 & May 15,2003 & 9:30:00 PM & 14.60 & 13.68 & 1.28 & -0.36 & 0.00 & 1 \\
\hline 313 & April 14, 2003 & 7:22:00 PM & 14.66 & 13.76 & 1.26 & -0.36 & 0.00 & 5 \\
\hline 314 & April 16, 2003 & 12:06:00 AM & 14.38 & 13.55 & 1.18 & -0.35 & 0.00 & 1 \\
\hline 315 & April 10, 2003 & 5:10:00 AM & 14.66 & 13.73 & 1.27 & -0.34 & 0.00 & 5 \\
\hline 316 & July 2, 2003 & 6:00:00 AM & 14.85 & 13.76 & 1.43 & -0.34 & 0.00 & 5 \\
\hline 317 & July 2,2003 & 6:04:00 AM & 14.85 & 13.76 & 1.43 & -0.34 & 0.00 & 5 \\
\hline 318 & April 21, 2003 & 7:32:00 AM & 14.84 & 13.88 & 1.29 & -0.33 & 0.00 & 1 \\
\hline 319 & April 6, 2003 & 8:12:00 PM & 14.37 & 13.53 & 1.17 & -0.33 & 0.00 & 2 \\
\hline 320 & July 7, 2003 & $12: 18: 00 \mathrm{AM}$ & 14.84 & 13.94 & 1.23 & -0.33 & 0.00 & 1 \\
\hline 321 & July 1, 2003 & 5:30:00 AM & 14.61 & 13.65 & 1.28 & -0.32 & 0.00 & 1 \\
\hline 322 & July 1, 2003 & $6: 14: 00$ AM & 14.61 & 13.65 & 1.28 & -0.32 & 0.00 & 5 \\
\hline 323 & June 19, 2003 & 5:24:00 AM & 15.08 & 13.90 & 1.50 & -0.32 & 0.00 & 5 \\
\hline 324 & May 5, 2003 & 7:30:00 PM & 14.61 & 13.72 & 1.21 & -0.32 & 0.00 & 5 \\
\hline 325 & May 5, 2003 & 8:42:00 AM & 14.61 & 13.72 & 1.21 & -0.32 & 0.00 & 1 \\
\hline 326 & May 8, 2003 & 5:48:00 AM & 14.80 & 13.83 & 1.28 & -0.31 & 0.00 & 5 \\
\hline 327 & June 15, 2003 & 8:02:00 PM & 14.64 & 13.78 & 1.17 & -0.31 & 0.00 & 5 \\
\hline 328 & August 21, 2003 & 9:28:00 PM & 15.32 & 13.63 & 1.99 & -0.30 & 0.00 & 5 \\
\hline 329 & July 28,2003 & $7: 16: 00$ AM & 14.60 & 13.77 & 1.13 & -0.30 & 0.00 & 1 \\
\hline 330 & October 26, 2003 & 3:50:00 PM & 14.60 & 13.49 & 1.40 & -0.29 & 0.00 & 6 \\
\hline
\end{tabular}




\begin{tabular}{|c|c|c|c|c|c|c|c|c|}
\hline $\begin{array}{l}\text { Record } \\
\text { Number }\end{array}$ & Date of Shipment & $\begin{array}{l}\text { Time of } \\
\text { Shipment }\end{array}$ & $\begin{array}{l}\text { Gross } \\
\text { Value }\end{array}$ & $\begin{array}{l}\text { Background } \\
\text { Measurement }\end{array}$ & $\begin{array}{l}\text { Standard } \\
\text { Deviation }\end{array}$ & Net Exposure & $\begin{array}{l}\text { Adjusted } \\
\text { Net } \\
\text { Exposure }\end{array}$ & $\begin{array}{c}\text { Route } \\
\text { Number }\end{array}$ \\
\hline 331 & September 21, 2003 & 8:14:00 PM & 15.51 & 13.84 & 1.96 & -0.29 & 0.00 & 5 \\
\hline 332 & June 17, 2003 & 5:30:00 AM & 14.61 & 13.73 & 1.16 & -0.28 & 0.00 & 5 \\
\hline 333 & May 7, 2003 & 10:42:00 PM & 14.83 & 13.83 & 1.28 & -0.28 & 0.00 & 1 \\
\hline 334 & August 26, 2003 & 8:00:00 PM & 14.84 & 13.60 & 1.52 & -0.28 & 0.00 & 5 \\
\hline 335 & June 22, 2003 & 7:06:00 PM & 14.84 & 13.83 & 1.28 & -0.27 & 0.00 & 2 \\
\hline 336 & October 27, 2003 & 4:44:00 AM & 14.37 & 13.40 & 1.24 & -0.27 & 0.00 & 5 \\
\hline 337 & October 2, 2003 & $6: 30: 00$ AM & 14.61 & 13.77 & 1.11 & -0.27 & 0.00 & 5 \\
\hline 338 & October 2, 2003 & $6: 34: 00$ AM & 14.61 & 13.77 & 1.11 & -0.27 & 0.00 & 5 \\
\hline 339 & July 22, 2003 & 5:58:00 AM & 15.13 & 13.91 & 1.49 & -0.27 & 0.00 & 1 \\
\hline 340 & February 23, 2003 & 7:40:00 PM & 15.52 & 13.83 & 1.96 & -0.26 & 0.00 & 1 \\
\hline 341 & September 18, 2003 & $6: 20: 00 \mathrm{AM}$ & 14.37 & 13.55 & 1.08 & -0.26 & 0.00 & 1 \\
\hline 342 & August 26, 2003 & 7:08:00 PM & 15.03 & 13.83 & 1.46 & -0.26 & 0.00 & 5 \\
\hline 343 & May 7, 2003 & 8:10:00 PM & 14.85 & 13.83 & 1.28 & -0.26 & 0.00 & 5 \\
\hline 344 & June 2, 2003 & $3: 22: 00$ AM & 14.84 & 13.67 & 1.43 & -0.26 & 0.00 & 5 \\
\hline 345 & April 23, 2003 & 11:50:00 PM & 14.61 & 13.70 & 1.17 & -0.26 & 0.00 & 1 \\
\hline 346 & August 13, 2003 & $10: 44: 00 \mathrm{AM}$ & 14.64 & 13.72 & 1.18 & -0.25 & 0.00 & 6 \\
\hline 347 & May 28,2003 & $5: 22: 00$ AM & 14.61 & 13.64 & 1.22 & -0.25 & 0.00 & 5 \\
\hline 348 & October 26, 2003 & 2:00:00 AM & 14.37 & 13.32 & 1.30 & -0.25 & 0.00 & 1 \\
\hline 349 & October 26, 2003 & 2:04:00 AM & 14.37 & 13.32 & 1.30 & -0.25 & 0.00 & 1 \\
\hline 350 & October 26, 2003 & 2:06:00 AM & 14.37 & 13.32 & 1.30 & -0.25 & 0.00 & 1 \\
\hline 351 & May 1, 2003 & $6: 26: 00 \mathrm{AM}$ & 14.84 & 13.72 & 1.37 & -0.25 & 0.00 & 5 \\
\hline 352 & June 2, 2003 & 5:18:00 AM & 14.85 & 13.67 & 1.43 & -0.25 & 0.00 & 5 \\
\hline 353 & June 2, 2003 & 5:26:00 AM & 14.85 & 13.67 & 1.43 & -0.25 & 0.00 & 5 \\
\hline 354 & June 5, 2003 & 5:48:00 AM & 15.32 & 13.98 & 1.59 & -0.25 & 0.00 & 5 \\
\hline 355 & September 18, 2003 & 11:16:00 PM & 14.61 & 13.60 & 1.26 & -0.25 & 0.00 & 1 \\
\hline 356 & June 20,2003 & $6: 14: 00$ AM & 16.32 & 13.99 & 2.58 & -0.25 & 0.00 & 5 \\
\hline 357 & December 8, 2003 & 8:14:00 AM & 14.35 & 13.44 & 1.16 & -0.25 & 0.00 & 1 \\
\hline 358 & December 17, 2003 & 5:50:00 PM & 14.41 & 13.42 & 1.24 & -0.25 & 0.00 & 1 \\
\hline 359 & September 17, 2003 & $10: 20: 00 \mathrm{AM}$ & 15.56 & 13.87 & 1.94 & -0.25 & 0.00 & 1 \\
\hline 360 & October 20, 2003 & 7:40:00 AM & 14.37 & 13.57 & 1.04 & -0.24 & 0.00 & 5 \\
\hline 361 & August 12, 2003 & 6:32:00 AM & 14.60 & 13.73 & 1.11 & -0.24 & 0.00 & 1 \\
\hline 362 & June 24,2003 & 10:06:00 AM & 14.85 & 13.75 & 1.34 & -0.24 & 0.00 & 5 \\
\hline 363 & May 28, 2003 & 5:02:00 PM & 14.84 & 13.85 & 1.23 & -0.24 & 0.00 & 5 \\
\hline
\end{tabular}




\begin{tabular}{|c|c|c|c|c|c|c|c|c|}
\hline $\begin{array}{l}\text { Record } \\
\text { Number }\end{array}$ & Date of Shipment & $\begin{array}{l}\text { Time of } \\
\text { Shipment }\end{array}$ & $\begin{array}{l}\text { Gross } \\
\text { Value }\end{array}$ & $\begin{array}{l}\text { Background } \\
\text { Measurement }\end{array}$ & $\begin{array}{l}\text { Standard } \\
\text { Deviation }\end{array}$ & Net Exposure & $\begin{array}{l}\text { Adjusted } \\
\text { Net } \\
\text { Exposure } \\
\end{array}$ & $\begin{array}{c}\text { Route } \\
\text { Number }\end{array}$ \\
\hline 364 & November 4, 2003 & $8: 44: 00$ AM & 14.56 & 13.49 & 1.31 & -0.24 & 0.00 & 1 \\
\hline 365 & July 10, 2003 & 6:40:00 PM & 14.82 & 13.91 & 1.15 & -0.24 & 0.00 & 5 \\
\hline 366 & June 22, 2003 & 7:16:00 PM & 14.88 & 13.83 & 1.28 & -0.23 & 0.00 & 2 \\
\hline 367 & May 15, 2003 & 5:32:00 PM & 14.83 & 13.81 & 1.25 & -0.23 & 0.00 & 5 \\
\hline 368 & June 19, 2003 & 5:58:00 PM & 14.78 & 13.90 & 1.11 & -0.23 & 0.00 & 5 \\
\hline 369 & October 12, 2003 & 3:16:00 AM & 14.61 & 13.62 & 1.21 & -0.22 & 0.00 & 1 \\
\hline 370 & June 18, 2003 & 5:52:00 AM & 14.85 & 13.79 & 1.28 & -0.22 & 0.00 & 5 \\
\hline 371 & June 29, 2003 & 11:54:00 PM & 14.84 & 13.71 & 1.34 & -0.22 & 0.00 & 1 \\
\hline 372 & June 29, 2003 & 11:58:00 PM & 14.84 & 13.71 & 1.34 & -0.22 & 0.00 & 1 \\
\hline 373 & April 9, 2003 & 5:26:00 AM & 15.04 & 13.66 & 1.59 & -0.21 & 0.00 & 5 \\
\hline 374 & May 14,2003 & 7:18:00 PM & 14.84 & 13.73 & 1.32 & -0.21 & 0.00 & 5 \\
\hline 375 & May 14,2003 & 7:20:00 PM & 14.84 & 13.73 & 1.32 & -0.21 & 0.00 & 5 \\
\hline 376 & May 5, 2003 & 4:56:00 AM & 15.09 & 13.70 & 1.60 & -0.21 & 0.00 & 5 \\
\hline 377 & June 1, 2003 & 7:32:00 PM & 14.64 & 13.70 & 1.15 & -0.21 & 0.00 & 1 \\
\hline 378 & June 1, 2003 & 7:40:00 PM & 14.64 & 13.70 & 1.15 & -0.21 & 0.00 & 5 \\
\hline 379 & September 7, 2003 & 9:52:00 PM & 14.78 & 13.82 & 1.16 & -0.21 & 0.00 & 5 \\
\hline 380 & April 23, 2003 & 7:32:00 PM & 14.85 & 13.80 & 1.25 & -0.20 & 0.00 & 1 \\
\hline 381 & September 25, 2003 & 11:58:00 PM & 14.85 & 13.82 & 1.23 & -0.20 & 0.00 & 1 \\
\hline 382 & September 26, 2003 & 5:30:00 AM & 14.85 & 13.82 & 1.23 & -0.20 & 0.00 & 1 \\
\hline 383 & September 26, 2003 & 5:32:00 AM & 14.85 & 13.82 & 1.23 & -0.20 & 0.00 & 1 \\
\hline 384 & June 23,2003 & 8:50:00 PM & 14.84 & 13.77 & 1.27 & -0.20 & 0.00 & 1 \\
\hline 385 & July 22, 2003 & 5:04:00 PM & 15.13 & 14.07 & 1.26 & -0.20 & 0.00 & 5 \\
\hline 386 & November 9, 2003 & 7:30:00 PM & 14.37 & 13.40 & 1.16 & -0.19 & 0.00 & 1 \\
\hline 387 & April 3, 2003 & 5:30:00 AM & 14.85 & 13.68 & 1.36 & -0.19 & 0.00 & 1 \\
\hline 388 & August 7, 2003 & 7:54:00 AM & 14.85 & 13.77 & 1.27 & -0.19 & 0.00 & 1 \\
\hline 389 & September 17, 2003 & 10:16:00 AM & 15.62 & 13.87 & 1.94 & -0.19 & 0.00 & 1 \\
\hline 390 & December 15, 2003 & 4:44:00 AM & 14.33 & 13.39 & 1.12 & -0.18 & 0.00 & 5 \\
\hline 391 & May 16, 2003 & $6: 18: 00 \mathrm{AM}$ & 14.79 & 13.68 & 1.28 & -0.17 & 0.00 & 5 \\
\hline 392 & July 24, 2003 & 6:30:00 AM & 15.08 & 13.89 & 1.36 & -0.17 & 0.00 & 1 \\
\hline 393 & July 24,2003 & $6: 32: 00 \mathrm{AM}$ & 15.08 & 13.89 & 1.36 & -0.17 & 0.00 & 1 \\
\hline 394 & October 16, 2003 & 1:30:00 AM & 14.61 & 13.60 & 1.18 & -0.17 & 0.00 & 1 \\
\hline 395 & May 21, 2003 & 7:00:00 PM & 15.02 & 13.84 & 1.35 & -0.17 & 0.00 & 5 \\
\hline 396 & September 23, 2003 & 11:36:00 PM & 15.57 & 13.99 & 1.74 & -0.16 & 0.00 & 1 \\
\hline
\end{tabular}




\begin{tabular}{|c|c|c|c|c|c|c|c|c|}
\hline $\begin{array}{l}\text { Record } \\
\text { Number }\end{array}$ & Date of Shipment & $\begin{array}{l}\text { Time of } \\
\text { Shipment }\end{array}$ & $\begin{array}{l}\text { Gross } \\
\text { Value }\end{array}$ & $\begin{array}{l}\text { Background } \\
\text { Measurement }\end{array}$ & $\begin{array}{l}\text { Standard } \\
\text { Deviation }\end{array}$ & Net Exposure & $\begin{array}{l}\text { Adjusted } \\
\text { Net } \\
\text { Exposure }\end{array}$ & $\begin{array}{c}\text { Route } \\
\text { Number }\end{array}$ \\
\hline 397 & August 25, 2003 & 7:04:00 AM & 14.85 & 13.66 & 1.34 & -0.15 & 0.00 & 5 \\
\hline 398 & April 16, 2003 & $12: 04: 00 \mathrm{AM}$ & 14.59 & 13.55 & 1.18 & -0.14 & 0.00 & 1 \\
\hline 399 & July 8, 2003 & 5:24:00 AM & 14.84 & 13.82 & 1.16 & -0.14 & 0.00 & 5 \\
\hline 400 & April 7, 2003 & $6: 12: 00 \mathrm{AM}$ & 14.56 & 13.53 & 1.17 & -0.14 & 0.00 & 5 \\
\hline 401 & July 8,2003 & 6:04:00 AM & 14.85 & 13.82 & 1.16 & -0.13 & 0.00 & 5 \\
\hline 402 & July 8,2003 & $6: 30: 00 \mathrm{AM}$ & 14.85 & 13.82 & 1.16 & -0.13 & 0.00 & 5 \\
\hline 403 & March 12, 2003 & 6:18:00 AM & 15.04 & 13.77 & 1.40 & -0.13 & 0.00 & 5 \\
\hline 404 & May 14, 2003 & $6: 30: 00$ AM & 14.85 & 13.62 & 1.36 & -0.13 & 0.00 & 5 \\
\hline 405 & March 19, 2003 & 5:04:00 AM & 14.56 & 13.51 & 1.18 & -0.13 & 0.00 & 5 \\
\hline 406 & September 9, 2003 & 5:46:00 AM & 15.09 & 13.81 & 1.41 & -0.12 & 0.00 & 1 \\
\hline 407 & September 9, 2003 & 5:48:00 AM & 15.09 & 13.81 & 1.41 & -0.12 & 0.00 & 1 \\
\hline 408 & September 9, 2003 & 5:50:00 AM & 15.09 & 13.81 & 1.41 & -0.12 & 0.00 & 1 \\
\hline 409 & May 19, 2003 & 5:48:00 AM & 14.59 & 13.65 & 1.06 & -0.12 & 0.00 & 5 \\
\hline 410 & May 15, 2003 & 9:32:00 PM & 14.84 & 13.68 & 1.28 & -0.12 & 0.00 & 1 \\
\hline 411 & September 25, 2003 & 7:46:00 AM & 15.09 & 13.99 & 1.21 & -0.11 & 0.00 & 1 \\
\hline 412 & September 25, 2003 & 7:52:00 AM & 15.09 & 13.99 & 1.21 & -0.11 & 0.00 & 1 \\
\hline 413 & July 1, 2003 & 10:20:00 PM & 15.08 & 13.76 & 1.43 & -0.11 & 0.00 & 1 \\
\hline 414 & July 2, 2003 & 1:20:00 AM & 15.08 & 13.76 & 1.43 & -0.11 & 0.00 & 1 \\
\hline 415 & June 15, 2003 & 10:42:00 PM & 14.84 & 13.78 & 1.17 & -0.11 & 0.00 & 2 \\
\hline 416 & September 9, 2003 & 6:20:00 PM & 15.27 & 13.90 & 1.48 & -0.11 & 0.00 & 1 \\
\hline 417 & July 13, 2003 & 6:44:00 PM & 14.88 & 13.91 & 1.07 & -0.10 & 0.00 & 5 \\
\hline 418 & May 19, 2003 & 7:26:00 AM & 14.61 & 13.65 & 1.06 & -0.10 & 0.00 & 6 \\
\hline 419 & July 2, 2003 & 4:20:00 AM & 15.09 & 13.76 & 1.43 & -0.10 & 0.00 & 5 \\
\hline 420 & June 16, 2003 & 5:26:00 AM & 14.85 & 13.78 & 1.17 & -0.10 & 0.00 & 5 \\
\hline 421 & June 16, 2003 & 5:34:00 AM & 14.85 & 13.78 & 1.17 & -0.10 & 0.00 & 5 \\
\hline 422 & June 16, 2003 & 6:06:00 AM & 14.85 & 13.78 & 1.17 & -0.10 & 0.00 & 2 \\
\hline 423 & August 5, 2003 & 6:06:00 AM & 14.61 & 13.57 & 1.13 & -0.09 & 0.00 & 1 \\
\hline 424 & August 5, 2003 & 6:10:00 AM & 14.61 & 13.57 & 1.13 & -0.09 & 0.00 & 1 \\
\hline 425 & August 15, 2003 & 5:58:00 AM & 14.79 & 13.75 & 1.13 & -0.09 & 0.00 & 5 \\
\hline 426 & April 6, 2003 & 8:14:00 PM & 14.61 & 13.53 & 1.17 & -0.09 & 0.00 & 2 \\
\hline 427 & March 11, 2003 & 10:56:00 PM & 15.08 & 13.77 & 1.40 & -0.09 & 0.00 & 1 \\
\hline 428 & July 6,2003 & $11: 32: 00$ PM & 15.08 & 13.94 & 1.23 & -0.09 & 0.00 & 2 \\
\hline 429 & July 7,2003 & $12: 20: 00 \mathrm{AM}$ & 15.08 & 13.94 & 1.23 & -0.09 & 0.00 & 1 \\
\hline
\end{tabular}




\begin{tabular}{|c|c|c|c|c|c|c|c|c|}
\hline $\begin{array}{l}\text { Record } \\
\text { Number }\end{array}$ & Date of Shipment & $\begin{array}{l}\text { Time of } \\
\text { Shipment }\end{array}$ & $\begin{array}{l}\text { Gross } \\
\text { Value }\end{array}$ & $\begin{array}{l}\text { Background } \\
\text { Measurement }\end{array}$ & $\begin{array}{l}\text { Standard } \\
\text { Deviation }\end{array}$ & Net Exposure & $\begin{array}{l}\text { Adjusted } \\
\text { Net } \\
\text { Exposure }\end{array}$ & $\begin{array}{c}\text { Route } \\
\text { Number }\end{array}$ \\
\hline 430 & August 19, 2003 & 5:42:00 AM & 15.08 & 13.86 & 1.31 & -0.09 & 0.00 & 1 \\
\hline 431 & August 19, 2003 & 6:00:00 AM & 15.08 & 13.86 & 1.31 & -0.09 & 0.00 & 5 \\
\hline 432 & August 19, 2003 & 6:02:00 AM & 15.08 & 13.86 & 1.31 & -0.09 & 0.00 & 5 \\
\hline 433 & June 19, 2003 & 5:28:00 AM & 15.32 & 13.90 & 1.50 & -0.08 & 0.00 & 1 \\
\hline 434 & May 29, 2003 & 5:40:00 AM & 14.84 & 13.76 & 1.16 & -0.08 & 0.00 & 5 \\
\hline 435 & May 29, 2003 & 5:50:00 AM & 14.84 & 13.76 & 1.16 & -0.08 & 0.00 & 5 \\
\hline 436 & March 11, 2003 & 11:32:00 PM & 15.09 & 13.77 & 1.40 & -0.08 & 0.00 & 5 \\
\hline 437 & March 17, 2003 & 5:56:00 AM & 15.53 & 13.77 & 1.83 & -0.08 & 0.00 & 5 \\
\hline 438 & April 16, 2003 & $12: 02: 00 \mathrm{AM}$ & 14.66 & 13.55 & 1.18 & -0.07 & 0.00 & 1 \\
\hline 439 & August 12, 2003 & 5:50:00 AM & 14.78 & 13.73 & 1.11 & -0.06 & 0.00 & 1 \\
\hline 440 & May 19,2003 & 5:50:00 AM & 14.65 & 13.65 & 1.06 & -0.06 & 0.00 & 5 \\
\hline 441 & May 28, 2003 & 4:00:00 PM & 15.02 & 13.85 & 1.23 & -0.06 & 0.00 & 5 \\
\hline 442 & September 25, 2003 & 7:50:00 AM & 15.14 & 13.99 & 1.21 & -0.06 & 0.00 & 1 \\
\hline 443 & May 20,2003 & 7:24:00 PM & 14.84 & 13.70 & 1.20 & -0.06 & 0.00 & 5 \\
\hline 444 & July 28, 2003 & $6: 10: 00 \mathrm{AM}$ & 14.84 & 13.77 & 1.13 & -0.06 & 0.00 & 5 \\
\hline 445 & June 16, 2003 & 11:10:00 PM & 14.84 & 13.73 & 1.16 & -0.05 & 0.00 & 1 \\
\hline 446 & June 26, 2003 & 4:22:00 AM & 14.61 & 13.53 & 1.13 & -0.05 & 0.00 & 1 \\
\hline 447 & June 17, 2003 & 6:14:00 AM & 14.85 & 13.73 & 1.16 & -0.04 & 0.00 & 5 \\
\hline 448 & September 9, 2003 & 8:32:00 PM & 14.84 & 13.73 & 1.15 & -0.04 & 0.00 & 1 \\
\hline 449 & August 15, 2003 & 6:32:00 AM & 14.84 & 13.75 & 1.13 & -0.04 & 0.00 & 1 \\
\hline 450 & May 28, 2003 & 8:16:00 PM & 14.88 & 13.76 & 1.16 & -0.04 & 0.00 & 5 \\
\hline 451 & July 10, 2003 & 6:38:00 PM & 15.02 & 13.91 & 1.15 & -0.04 & 0.00 & 5 \\
\hline 452 & May 5, 2003 & 7:28:00 PM & 14.89 & 13.72 & 1.21 & -0.04 & 0.00 & 5 \\
\hline 453 & June 22, 2003 & 6:26:00 PM & 15.08 & 13.83 & 1.28 & -0.03 & 0.00 & 5 \\
\hline 454 & June 22, 2003 & 7:38:00 PM & 15.08 & 13.83 & 1.28 & -0.03 & 0.00 & 1 \\
\hline 455 & October 27, 2003 & 4:46:00 AM & 14.61 & 13.40 & 1.24 & -0.03 & 0.00 & 5 \\
\hline 456 & October 2, 2003 & 6:42:00 AM & 14.85 & 13.77 & 1.11 & -0.03 & 0.00 & 5 \\
\hline 457 & September 18, 2003 & 1:00:00 AM & 14.61 & 13.55 & 1.08 & -0.02 & 0.00 & 1 \\
\hline 458 & August 28, 2003 & 5:58:00 AM & 14.85 & 13.72 & 1.15 & -0.02 & 0.00 & 5 \\
\hline 459 & August 28, 2003 & $6: 10: 00 \mathrm{AM}$ & 14.85 & 13.72 & 1.15 & -0.02 & 0.00 & 5 \\
\hline 460 & August 28, 2003 & $6: 12: 00 \mathrm{AM}$ & 14.85 & 13.72 & 1.15 & -0.02 & 0.00 & 5 \\
\hline 461 & September 30, 2003 & 7:38:00 AM & 15.09 & 13.75 & 1.36 & -0.02 & 0.00 & 5 \\
\hline 462 & July 30, 2003 & 6:04:00 AM & 15.08 & 13.84 & 1.26 & -0.02 & 0.00 & 5 \\
\hline
\end{tabular}




\begin{tabular}{|c|c|c|c|c|c|c|c|c|}
\hline $\begin{array}{l}\text { Record } \\
\text { Number }\end{array}$ & Date of Shipment & $\begin{array}{l}\text { Time of } \\
\text { Shipment }\end{array}$ & $\begin{array}{l}\text { Gross } \\
\text { Value }\end{array}$ & $\begin{array}{l}\text { Background } \\
\text { Measurement }\end{array}$ & $\begin{array}{l}\text { Standard } \\
\text { Deviation }\end{array}$ & Net Exposure & $\begin{array}{l}\text { Adjusted } \\
\text { Net } \\
\text { Exposure } \\
\end{array}$ & $\begin{array}{c}\text { Route } \\
\text { Number }\end{array}$ \\
\hline 463 & July 30, 2003 & 6:08:00 AM & 15.08 & 13.84 & 1.26 & -0.02 & 0.00 & 5 \\
\hline 464 & July 30, 2003 & 6:10:00 AM & 15.08 & 13.84 & 1.26 & -0.02 & 0.00 & 5 \\
\hline 465 & July 30, 2003 & 6:30:00 AM & 15.08 & 13.84 & 1.26 & -0.02 & 0.00 & 5 \\
\hline 466 & December 18, 2003 & 5:48:00 AM & 14.56 & 13.40 & 1.18 & -0.02 & 0.00 & 5 \\
\hline 467 & August 11, 2003 & $6: 12: 00$ AM & 14.89 & 13.69 & 1.22 & -0.01 & 0.00 & 5 \\
\hline 468 & August 4, 2003 & $5: 24: 00$ AM & 14.85 & 13.64 & 1.22 & -0.01 & 0.00 & 5 \\
\hline 469 & August 12, 2003 & 6:12:00 AM & 14.83 & 13.73 & 1.11 & -0.01 & 0.00 & 1 \\
\hline 470 & September 19, 2003 & 12:54:00 AM & 14.85 & 13.60 & 1.26 & -0.01 & 0.00 & 1 \\
\hline 471 & May 28, 2003 & 5:06:00 PM & 15.07 & 13.85 & 1.23 & -0.01 & 0.00 & 5 \\
\hline 472 & June 1, 2003 & 1:42:00 PM & 14.84 & 13.70 & 1.15 & -0.01 & 0.00 & 5 \\
\hline 473 & October 23, 2003 & 1:58:00 AM & 14.90 & 13.62 & 1.29 & -0.01 & 0.00 & 1 \\
\hline 474 & September 17, 2003 & 10:18:00 AM & 15.80 & 13.87 & 1.94 & -0.01 & 0.00 & 1 \\
\hline 475 & August 7, 2003 & 6:00:00 AM & 14.85 & 13.59 & 1.26 & 0.00 & 0.00 & 1 \\
\hline 476 & August 7, 2003 & $6: 20: 00 \mathrm{AM}$ & 14.85 & 13.59 & 1.26 & 0.00 & 0.00 & 1 \\
\hline 477 & August 7, 2003 & $6: 22: 00 \mathrm{AM}$ & 14.85 & 13.59 & 1.26 & 0.00 & 0.00 & 1 \\
\hline 478 & August 7, 2003 & $6: 46: 00 \mathrm{AM}$ & 14.85 & 13.59 & 1.26 & 0.00 & 0.00 & 1 \\
\hline 479 & August 7, 2003 & 7:10:00 AM & 14.85 & 13.59 & 1.26 & 0.00 & 0.00 & 1 \\
\hline 480 & April 17, 2003 & 7:06:00 PM & 15.08 & 13.78 & 1.30 & 0.00 & 0.00 & 5 \\
\hline 481 & April 27, 2003 & 8:28:00 PM & 14.83 & 13.68 & 1.15 & 0.00 & 0.00 & 5 \\
\hline 482 & August 21, 2003 & 5:34:00 AM & 15.62 & 13.63 & 1.99 & 0.00 & 0.00 & 1 \\
\hline 483 & October 20, 2003 & $3: 48: 00 \mathrm{AM}$ & 14.61 & 13.57 & 1.04 & 0.00 & 0.00 & 1 \\
\hline 484 & September 17, 2003 & 6:34:00 AM & 14.85 & 13.76 & 1.08 & 0.01 & 0.01 & 5 \\
\hline 485 & October 13, 2003 & 7:48:00 AM & 14.65 & 13.59 & 1.05 & 0.01 & 0.01 & 5 \\
\hline 486 & April 28, 2003 & 6:06:00 AM & 14.85 & 13.68 & 1.15 & 0.02 & 0.02 & 5 \\
\hline 487 & October 22, 2003 & 7:06:00 AM & 14.61 & 13.54 & 1.05 & 0.02 & 0.02 & 5 \\
\hline 488 & June 3,2003 & 10:36:00 PM & 15.13 & 13.91 & 1.20 & 0.02 & 0.02 & 1 \\
\hline 489 & July 20, 2003 & 5:00:00 PM & 15.13 & 13.86 & 1.25 & 0.03 & 0.03 & 5 \\
\hline 490 & May 14, 2003 & 7:14:00 PM & 15.08 & 13.73 & 1.32 & 0.03 & 0.03 & 5 \\
\hline 491 & June 30, 2003 & $6: 20: 00 \mathrm{AM}$ & 15.09 & 13.71 & 1.34 & 0.03 & 0.03 & 5 \\
\hline 492 & April 23, 2003 & 7:38:00 PM & 15.09 & 13.80 & 1.25 & 0.04 & 0.04 & 1 \\
\hline 493 & December 8, 2003 & 6:18:00 AM & 14.66 & 13.55 & 1.07 & 0.04 & 0.04 & 5 \\
\hline 494 & September 26, 2003 & $12: 02: 00 \mathrm{AM}$ & 15.09 & 13.82 & 1.23 & 0.04 & 0.04 & 1 \\
\hline 495 & May 9, 2003 & 6:02:00 AM & 14.84 & 13.61 & 1.19 & 0.04 & 0.04 & 5 \\
\hline
\end{tabular}




\begin{tabular}{|c|c|c|c|c|c|c|c|c|}
\hline $\begin{array}{l}\text { Record } \\
\text { Number }\end{array}$ & Date of Shipment & $\begin{array}{l}\text { Time of } \\
\text { Shipment }\end{array}$ & $\begin{array}{l}\text { Gross } \\
\text { Value }\end{array}$ & $\begin{array}{l}\text { Background } \\
\text { Measurement }\end{array}$ & $\begin{array}{l}\text { Standard } \\
\text { Deviation }\end{array}$ & Net Exposure & $\begin{array}{l}\text { Adjusted } \\
\text { Net } \\
\text { Exposure }\end{array}$ & $\begin{array}{c}\text { Route } \\
\text { Number }\end{array}$ \\
\hline 496 & June 23,2003 & 10:28:00 PM & 15.08 & 13.77 & 1.27 & 0.04 & 0.04 & 1 \\
\hline 497 & November 2, 2003 & 7:20:00 PM & 14.90 & 13.51 & 1.35 & 0.04 & 0.04 & 1 \\
\hline 498 & November 4, 2003 & 8:42:00 AM & 14.85 & 13.49 & 1.31 & 0.05 & 0.05 & 1 \\
\hline 499 & February 16, 2003 & 5:46:00 PM & 14.61 & 13.42 & 1.14 & 0.05 & 0.05 & 6 \\
\hline 500 & April 23, 2003 & 5:58:00 AM & 16.13 & 14.03 & 2.05 & 0.05 & 0.05 & 2 \\
\hline 501 & June 8, 2003 & 9:00:00 PM & 16.11 & 14.03 & 2.03 & 0.05 & 0.05 & 5 \\
\hline 502 & July 16,2003 & 5:54:00 AM & 15.13 & 13.84 & 1.23 & 0.06 & 0.06 & 5 \\
\hline 503 & July 16, 2003 & $6: 14: 00$ AM & 15.13 & 13.84 & 1.23 & 0.06 & 0.06 & 5 \\
\hline 504 & July 9, 2003 & $6: 12: 00 \mathrm{AM}$ & 14.85 & 13.71 & 1.07 & 0.07 & 0.07 & 5 \\
\hline 505 & July 24, 2003 & 6:08:00 AM & 15.32 & 13.89 & 1.36 & 0.07 & 0.07 & 1 \\
\hline 506 & June 15, 2003 & 7:58:00 PM & 15.03 & 13.78 & 1.17 & 0.08 & 0.08 & 5 \\
\hline 507 & December 2, 2003 & 7:06:00 PM & 14.85 & 13.47 & 1.29 & 0.09 & 0.09 & 5 \\
\hline 508 & April 23, 2003 & 7:36:00 PM & 15.14 & 13.80 & 1.25 & 0.09 & 0.09 & 1 \\
\hline 509 & October 7, 2003 & $7: 10: 00$ AM & 15.04 & 13.84 & 1.10 & 0.10 & 0.10 & 1 \\
\hline 510 & July 8,2003 & $12: 32: 00 \mathrm{AM}$ & 15.08 & 13.82 & 1.16 & 0.10 & 0.10 & 1 \\
\hline 511 & June 19, 2003 & $6: 02: 00$ AM & 15.51 & 13.90 & 1.50 & 0.11 & 0.11 & 2 \\
\hline 512 & October 6, 2003 & 7:40:00 AM & 15.33 & 13.75 & 1.47 & 0.11 & 0.11 & 5 \\
\hline 513 & September 9, 2003 & 6:00:00 AM & 15.33 & 13.81 & 1.41 & 0.12 & 0.12 & 5 \\
\hline 514 & October 30, 2003 & 7:50:00 AM & 14.37 & 13.21 & 1.04 & 0.12 & 0.12 & 1 \\
\hline 515 & May 15, 2003 & 9:34:00 PM & 15.08 & 13.68 & 1.28 & 0.12 & 0.12 & 1 \\
\hline 516 & May 18, 2003 & 8:22:00 PM & 14.84 & 13.65 & 1.06 & 0.13 & 0.13 & 1 \\
\hline 517 & May 19, 2003 & 5:04:00 AM & 14.84 & 13.65 & 1.06 & 0.13 & 0.13 & 5 \\
\hline 518 & August 4, 2003 & 11:08:00 PM & 14.84 & 13.57 & 1.13 & 0.14 & 0.14 & 6 \\
\hline 519 & April 10, 2003 & 5:04:00 AM & 15.14 & 13.73 & 1.27 & 0.14 & 0.14 & 5 \\
\hline 520 & July 1,2003 & 5:02:00 PM & 15.13 & 13.80 & 1.19 & 0.14 & 0.14 & 5 \\
\hline 521 & July 1,2003 & 7:12:00 PM & 15.13 & 13.80 & 1.19 & 0.14 & 0.14 & 5 \\
\hline 522 & June 16,2003 & 6:04:00 AM & 15.09 & 13.78 & 1.17 & 0.14 & 0.14 & 5 \\
\hline 523 & March 9, 2003 & 11:32:00 PM & 15.28 & 13.55 & 1.59 & 0.14 & 0.14 & 2 \\
\hline 524 & July 1,2003 & $12: 16: 00 \mathrm{AM}$ & 15.08 & 13.65 & 1.28 & 0.15 & 0.15 & 1 \\
\hline 525 & May 11, 2003 & 5:36:00 PM & 14.84 & 13.62 & 1.07 & 0.15 & 0.15 & 5 \\
\hline 526 & July 6,2003 & 11:36:00 PM & 15.32 & 13.94 & 1.23 & 0.15 & 0.15 & 1 \\
\hline 527 & July 1, 2003 & $6: 12: 00 \mathrm{AM}$ & 15.09 & 13.65 & 1.28 & 0.16 & 0.16 & 5 \\
\hline 528 & October 2, 2003 & 6:32:00 AM & 15.04 & 13.77 & 1.11 & 0.16 & 0.16 & 5 \\
\hline
\end{tabular}




\begin{tabular}{|c|c|c|c|c|c|c|c|c|}
\hline $\begin{array}{l}\text { Record } \\
\text { Number }\end{array}$ & Date of Shipment & $\begin{array}{l}\text { Time of } \\
\text { Shipment }\end{array}$ & $\begin{array}{l}\text { Gross } \\
\text { Value }\end{array}$ & $\begin{array}{l}\text { Background } \\
\text { Measurement }\end{array}$ & $\begin{array}{l}\text { Standard } \\
\text { Deviation }\end{array}$ & Net Exposure & $\begin{array}{l}\text { Adjusted } \\
\text { Net } \\
\text { Exposure } \\
\end{array}$ & $\begin{array}{c}\text { Route } \\
\text { Number }\end{array}$ \\
\hline 529 & October 1, 2003 & 6:58:00 AM & 15.09 & 13.74 & 1.19 & 0.16 & 0.16 & 1 \\
\hline 530 & May 29, 2003 & 5:38:00 AM & 15.08 & 13.76 & 1.16 & 0.16 & 0.16 & 5 \\
\hline 531 & August 4, 2003 & 6:02:00 AM & 15.03 & 13.64 & 1.22 & 0.17 & 0.17 & 5 \\
\hline 532 & October 8, 2003 & 9:14:00 AM & 15.33 & 13.89 & 1.27 & 0.17 & 0.17 & 5 \\
\hline 533 & July 11,2003 & 5:54:00 AM & 15.08 & 13.78 & 1.13 & 0.17 & 0.17 & 1 \\
\hline 534 & July 11, 2003 & 6:04:00 AM & 15.08 & 13.78 & 1.13 & 0.17 & 0.17 & 5 \\
\hline 535 & July 11, 2003 & 6:06:00 AM & 15.08 & 13.78 & 1.13 & 0.17 & 0.17 & 5 \\
\hline 536 & July 11,2003 & $7: 10: 00$ AM & 15.08 & 13.78 & 1.13 & 0.17 & 0.17 & 5 \\
\hline 537 & August 11, 2003 & 6:16:00 AM & 15.08 & 13.69 & 1.22 & 0.18 & 0.18 & 5 \\
\hline 538 & June 16, 2003 & 11:06:00 PM & 15.08 & 13.73 & 1.16 & 0.19 & 0.19 & 1 \\
\hline 539 & June 26, 2003 & 1:30:00 AM & 14.85 & 13.53 & 1.13 & 0.19 & 0.19 & 1 \\
\hline 540 & June 26, 2003 & $5: 10: 00 \mathrm{AM}$ & 14.85 & 13.53 & 1.13 & 0.19 & 0.19 & 6 \\
\hline 541 & June 26,2003 & $6: 00: 00 \mathrm{AM}$ & 14.85 & 13.53 & 1.13 & 0.19 & 0.19 & 5 \\
\hline 542 & October 21, 2003 & $12: 52: 00 \mathrm{PM}$ & 15.08 & 13.71 & 1.17 & 0.20 & 0.20 & 1 \\
\hline 543 & October 21, 2003 & 4:06:00 PM & 15.08 & 13.71 & 1.17 & 0.20 & 0.20 & 1 \\
\hline 544 & June 17, 2003 & $6: 10: 00 \mathrm{AM}$ & 15.09 & 13.73 & 1.16 & 0.20 & 0.20 & 5 \\
\hline 545 & July 6, 2003 & 8:26:00 PM & 15.37 & 13.94 & 1.23 & 0.20 & 0.20 & 2 \\
\hline 546 & October 22, 2003 & 5:30:00 AM & 14.79 & 13.54 & 1.05 & 0.20 & 0.20 & 5 \\
\hline 547 & July 14, 2003 & 5:08:00 AM & 15.08 & 13.75 & 1.13 & 0.20 & 0.20 & 5 \\
\hline 548 & July 14, 2003 & $5: 22: 00 \mathrm{AM}$ & 15.08 & 13.75 & 1.13 & 0.20 & 0.20 & 5 \\
\hline 549 & August 14, 2003 & 8:34:00 PM & 15.08 & 13.75 & 1.13 & 0.20 & 0.20 & 1 \\
\hline 550 & October 7, 2003 & $6: 50: 00 \mathrm{AM}$ & 15.14 & 13.84 & 1.10 & 0.20 & 0.20 & 5 \\
\hline 551 & June 22, 2003 & $10: 02: 00 \mathrm{AM}$ & 15.32 & 13.83 & 1.28 & 0.21 & 0.21 & 5 \\
\hline 552 & September 10, 2003 & 6:10:00 AM & 15.09 & 13.73 & 1.15 & 0.21 & 0.21 & 5 \\
\hline 553 & October 13, 2003 & 7:46:00 AM & 14.85 & 13.59 & 1.05 & 0.21 & 0.21 & 5 \\
\hline 554 & October 13, 2003 & 7:50:00 AM & 14.85 & 13.59 & 1.05 & 0.21 & 0.21 & 6 \\
\hline 555 & June 4, 2003 & $6: 24: 00$ AM & 15.32 & 13.91 & 1.20 & 0.21 & 0.21 & 5 \\
\hline 556 & August 4, 2003 & 7:26:00 AM & 15.08 & 13.64 & 1.22 & 0.22 & 0.22 & 1 \\
\hline 557 & September 17, 2003 & 9:44:00 PM & 14.85 & 13.55 & 1.08 & 0.22 & 0.22 & 1 \\
\hline 558 & August 28, 2003 & 1:00:00 AM & 15.09 & 13.72 & 1.15 & 0.22 & 0.22 & 1 \\
\hline 559 & August 28, 2003 & $6: 04: 00 \mathrm{AM}$ & 15.09 & 13.72 & 1.15 & 0.22 & 0.22 & 1 \\
\hline 560 & September 30, 2003 & 7:34:00 AM & 15.33 & 13.75 & 1.36 & 0.22 & 0.22 & 1 \\
\hline 561 & September 30, 2003 & 7:36:00 AM & 15.33 & 13.75 & 1.36 & 0.22 & 0.22 & 5 \\
\hline
\end{tabular}




\begin{tabular}{|c|c|c|c|c|c|c|c|c|}
\hline $\begin{array}{l}\text { Record } \\
\text { Number }\end{array}$ & Date of Shipment & $\begin{array}{l}\text { Time of } \\
\text { Shipment }\end{array}$ & $\begin{array}{l}\text { Gross } \\
\text { Value }\end{array}$ & $\begin{array}{l}\text { Background } \\
\text { Measurement }\end{array}$ & $\begin{array}{l}\text { Standard } \\
\text { Deviation }\end{array}$ & Net Exposure & $\begin{array}{l}\text { Adjusted } \\
\text { Net } \\
\text { Exposure }\end{array}$ & $\begin{array}{c}\text { Route } \\
\text { Number }\end{array}$ \\
\hline 562 & September 30, 2003 & 7:40:00 AM & 15.33 & 13.75 & 1.36 & 0.22 & 0.22 & 5 \\
\hline 563 & July 30, 2003 & 6:06:00 AM & 15.32 & 13.84 & 1.26 & 0.22 & 0.22 & 1 \\
\hline 564 & August 24, 2003 & 4:48:00 PM & 15.07 & 13.73 & 1.12 & 0.22 & 0.22 & 1 \\
\hline 565 & July 29, 2003 & $6: 22: 00 \mathrm{AM}$ & 15.32 & 13.91 & 1.19 & 0.23 & 0.23 & 5 \\
\hline 566 & July 29, 2003 & $6: 46: 00 \mathrm{AM}$ & 15.32 & 13.91 & 1.19 & 0.23 & 0.23 & 1 \\
\hline 567 & August 12, 2003 & 6:30:00 AM & 15.07 & 13.73 & 1.11 & 0.23 & 0.23 & 1 \\
\hline 568 & September 19, 2003 & $12: 52: 00 \mathrm{AM}$ & 15.09 & 13.60 & 1.26 & 0.23 & 0.23 & 1 \\
\hline 569 & April 2, 2003 & $5: 20: 00$ AM & 15.57 & 13.87 & 1.46 & 0.24 & 0.24 & 1 \\
\hline 570 & April 27, 2003 & 8:30:00 PM & 15.08 & 13.68 & 1.15 & 0.25 & 0.25 & 5 \\
\hline 571 & July 16, 2003 & 6:30:00 AM & 15.32 & 13.84 & 1.23 & 0.25 & 0.25 & 1 \\
\hline 572 & October 22, 2003 & 5:32:00 AM & 14.85 & 13.54 & 1.05 & 0.26 & 0.26 & 5 \\
\hline 573 & October 22, 2003 & 7:08:00 AM & 14.85 & 13.54 & 1.05 & 0.26 & 0.26 & 5 \\
\hline 574 & June 29, 2003 & 11:52:00 PM & 15.32 & 13.71 & 1.34 & 0.26 & 0.26 & 5 \\
\hline 575 & August 22, 2003 & 4:58:00 AM & 15.08 & 13.59 & 1.21 & 0.28 & 0.28 & 5 \\
\hline 576 & May 5, 2003 & $6: 12: 00 \mathrm{AM}$ & 15.58 & 13.70 & 1.60 & 0.28 & 0.28 & 5 \\
\hline 577 & November 4, 2003 & 3:20:00 PM & 15.09 & 13.49 & 1.31 & 0.29 & 0.29 & 1 \\
\hline 578 & August 11, 2003 & 10:20:00 PM & 15.13 & 13.73 & 1.11 & 0.29 & 0.29 & 6 \\
\hline 579 & August 11, 2003 & 7:50:00 PM & 15.13 & 13.73 & 1.11 & 0.29 & 0.29 & 5 \\
\hline 580 & July 8, 2003 & 10:30:00 PM & 15.08 & 13.71 & 1.07 & 0.30 & 0.30 & 1 \\
\hline 581 & March 16, 2003 & 6:44:00 PM & 15.28 & 13.77 & 1.21 & 0.30 & 0.30 & 5 \\
\hline 582 & July 9, 2003 & $6: 14: 00$ AM & 15.09 & 13.71 & 1.07 & 0.31 & 0.31 & 5 \\
\hline 583 & July 9,2003 & $6: 40: 00 \mathrm{AM}$ & 15.09 & 13.71 & 1.07 & 0.31 & 0.31 & 5 \\
\hline 584 & September 7, 2003 & $10: 14: 00 \mathrm{AM}$ & 15.56 & 13.87 & 1.38 & 0.31 & 0.31 & 1 \\
\hline 585 & September 25, 2003 & 7:54:00 AM & 15.52 & 13.99 & 1.21 & 0.32 & 0.32 & 1 \\
\hline 586 & December 10, 2003 & 3:30:00 AM & 15.10 & 13.52 & 1.26 & 0.32 & 0.32 & 5 \\
\hline 587 & May 19,2003 & 5:52:00 AM & 15.04 & 13.65 & 1.06 & 0.33 & 0.33 & 5 \\
\hline 588 & October 30, 2003 & 1:28:00 AM & 14.85 & 13.36 & 1.16 & 0.33 & 0.33 & 1 \\
\hline 589 & October 30, 2003 & 7:20:00 AM & 14.85 & 13.36 & 1.16 & 0.33 & 0.33 & 1 \\
\hline 590 & October 30, 2003 & 7:30:00 AM & 14.85 & 13.36 & 1.16 & 0.33 & 0.33 & 1 \\
\hline 591 & May 11, 2003 & 5:54:00 PM & 15.03 & 13.62 & 1.07 & 0.34 & 0.34 & 5 \\
\hline 592 & July 8,2003 & $12: 30: 00 \mathrm{AM}$ & 15.32 & 13.82 & 1.16 & 0.34 & 0.34 & 1 \\
\hline 593 & September 19, 2003 & 9:06:00 AM & 15.33 & 13.78 & 1.21 & 0.34 & 0.34 & 1 \\
\hline 594 & June 11, 2003 & 5:52:00 PM & 15.32 & 13.80 & 1.18 & 0.35 & 0.35 & 1 \\
\hline
\end{tabular}




\begin{tabular}{|c|c|c|c|c|c|c|c|c|}
\hline $\begin{array}{l}\text { Record } \\
\text { Number }\end{array}$ & Date of Shipment & $\begin{array}{l}\text { Time of } \\
\text { Shipment }\end{array}$ & $\begin{array}{l}\text { Gross } \\
\text { Value }\end{array}$ & $\begin{array}{l}\text { Background } \\
\text { Measurement }\end{array}$ & $\begin{array}{l}\text { Standard } \\
\text { Deviation }\end{array}$ & Net Exposure & $\begin{array}{l}\text { Adjusted } \\
\text { Net } \\
\text { Exposure }\end{array}$ & $\begin{array}{c}\text { Route } \\
\text { Number }\end{array}$ \\
\hline 595 & April 21, 2003 & 6:02:00 AM & 15.52 & 13.88 & 1.29 & 0.35 & 0.35 & 2 \\
\hline 596 & September 25, 2003 & 9:34:00 AM & 15.56 & 13.99 & 1.21 & 0.36 & 0.36 & 5 \\
\hline 597 & September 25, 2003 & 9:38:00 AM & 15.56 & 13.99 & 1.21 & 0.36 & 0.36 & 5 \\
\hline 598 & April 29, 2003 & 10:56:00 PM & 16.57 & 13.82 & 2.36 & 0.39 & 0.39 & 1 \\
\hline 599 & October 1, 2003 & $5: 44: 00$ AM & 15.33 & 13.74 & 1.19 & 0.40 & 0.40 & 5 \\
\hline 600 & October 1, 2003 & 6:02:00 AM & 15.33 & 13.74 & 1.19 & 0.40 & 0.40 & 5 \\
\hline 601 & May 29, 2003 & 5:34:00 AM & 15.32 & 13.76 & 1.16 & 0.40 & 0.40 & 5 \\
\hline 602 & May 8, 2003 & $12: 54: 00$ AM & 15.52 & 13.83 & 1.28 & 0.41 & 0.41 & 1 \\
\hline 603 & August 11, 2003 & $6: 14: 00$ AM & 15.32 & 13.69 & 1.22 & 0.42 & 0.42 & 5 \\
\hline 604 & October 26, 2003 & 2:02:00 AM & 15.04 & 13.32 & 1.30 & 0.42 & 0.42 & 1 \\
\hline 605 & June 22,2003 & 8:14:00 PM & 21.48 & 14.16 & 6.90 & 0.42 & 0.42 & 1 \\
\hline 606 & August 12, 2003 & 5:42:00 AM & 15.27 & 13.73 & 1.11 & 0.43 & 0.43 & 5 \\
\hline 607 & June 16, 2003 & 11:00:00 PM & 15.32 & 13.73 & 1.16 & 0.43 & 0.43 & 5 \\
\hline 608 & June 26, 2003 & 5:46:00 AM & 15.09 & 13.53 & 1.13 & 0.43 & 0.43 & 5 \\
\hline 609 & July 2, 2003 & 6:06:00 AM & 15.63 & 13.76 & 1.43 & 0.44 & 0.44 & 5 \\
\hline 610 & August 21, 2003 & $6: 12: 00 \mathrm{AM}$ & 16.07 & 13.63 & 1.99 & 0.45 & 0.45 & 5 \\
\hline 611 & November 12, 2003 & 2:30:00 PM & 16.77 & 14.66 & 1.66 & 0.45 & 0.45 & 5 \\
\hline 612 & August 19, 2003 & 6:18:00 AM & 15.62 & 13.86 & 1.31 & 0.45 & 0.45 & 1 \\
\hline 613 & June 18, 2003 & 5:48:00 AM & 15.52 & 13.79 & 1.28 & 0.45 & 0.45 & 1 \\
\hline 614 & December 18, 2003 & 5:46:00 AM & 15.04 & 13.40 & 1.18 & 0.46 & 0.46 & 5 \\
\hline 615 & September 11, 2003 & 8:56:00 AM & 15.33 & 13.57 & 1.30 & 0.46 & 0.46 & 1 \\
\hline 616 & August 4, 2003 & 6:00:00 AM & 15.33 & 13.64 & 1.22 & 0.47 & 0.47 & 2 \\
\hline 617 & April 23, 2003 & 7:34:00 PM & 15.52 & 13.80 & 1.25 & 0.47 & 0.47 & 5 \\
\hline 618 & December 3, 2003 & 9:00:00 PM & 15.28 & 13.61 & 1.19 & 0.48 & 0.48 & 1 \\
\hline 619 & July 16, 2003 & $6: 20: 00 \mathrm{AM}$ & 15.56 & 13.84 & 1.23 & 0.49 & 0.49 & 5 \\
\hline 620 & September 28, 2003 & 3:22:00 AM & 15.33 & 13.78 & 1.04 & 0.51 & 0.51 & 5 \\
\hline 621 & September 28, 2003 & 4:10:00 AM & 15.33 & 13.78 & 1.04 & 0.51 & 0.51 & 1 \\
\hline 622 & July 29, 2003 & 7:28:00 AM & 15.62 & 13.91 & 1.19 & 0.53 & 0.53 & 5 \\
\hline 623 & July 17, 2003 & 4:30:00 AM & 15.32 & 13.72 & 1.07 & 0.53 & 0.53 & 5 \\
\hline 624 & April 13, 2003 & 1:44:00 PM & 15.33 & 13.55 & 1.25 & 0.53 & 0.53 & 1 \\
\hline 625 & July 7,2003 & 8:06:00 PM & 15.51 & 13.82 & 1.16 & 0.53 & 0.53 & 5 \\
\hline 626 & April 29, 2003 & 5:52:00 PM & 15.57 & 13.71 & 1.32 & 0.53 & 0.53 & 1 \\
\hline 627 & October 28, 2003 & 8:10:00 PM & 15.32 & 13.54 & 1.24 & 0.54 & 0.54 & 1 \\
\hline
\end{tabular}




\begin{tabular}{|c|c|c|c|c|c|c|c|c|}
\hline $\begin{array}{l}\text { Record } \\
\text { Number }\end{array}$ & Date of Shipment & $\begin{array}{c}\text { Time of } \\
\text { Shipment }\end{array}$ & $\begin{array}{l}\text { Gross } \\
\text { Value }\end{array}$ & $\begin{array}{l}\text { Background } \\
\text { Measurement }\end{array}$ & $\begin{array}{l}\text { Standard } \\
\text { Deviation }\end{array}$ & Net Exposure & $\begin{array}{l}\text { Adjusted } \\
\text { Net } \\
\text { Exposure } \\
\end{array}$ & $\begin{array}{c}\text { Route } \\
\text { Number }\end{array}$ \\
\hline 628 & June 24, 2003 & 10:24:00 PM & 15.32 & 13.57 & 1.19 & 0.56 & 0.56 & 1 \\
\hline 629 & July 23, 2003 & 8:50:00 PM & 15.81 & 13.89 & 1.36 & 0.56 & 0.56 & 5 \\
\hline 630 & September 26, 2003 & $12: 00: 00$ AM & 15.62 & 13.82 & 1.23 & 0.57 & 0.57 & 5 \\
\hline 631 & October 15, 2003 & $6: 34: 00$ PM & 15.56 & 13.82 & 1.17 & 0.57 & 0.57 & 1 \\
\hline 632 & October 30, 2003 & 2:42:00 AM & 15.09 & 13.36 & 1.16 & 0.57 & 0.57 & 5 \\
\hline 633 & October 30, 2003 & 2:52:00 AM & 15.09 & 13.36 & 1.16 & 0.57 & 0.57 & 5 \\
\hline 634 & October 30, 2003 & 7:26:00 AM & 15.09 & 13.36 & 1.16 & 0.57 & 0.57 & 1 \\
\hline 635 & October 7, 2003 & $6: 54: 00 \mathrm{AM}$ & 15.52 & 13.84 & 1.10 & 0.58 & 0.58 & 1 \\
\hline 636 & July 7,2003 & 9:30:00 PM & 15.56 & 13.82 & 1.16 & 0.58 & 0.58 & 1 \\
\hline 637 & December 14, 2003 & 4:28:00 PM & 16.12 & 14.08 & 1.45 & 0.59 & 0.59 & 1 \\
\hline 638 & September 25, 2003 & 9:36:00 AM & 15.80 & 13.99 & 1.21 & 0.60 & 0.60 & 5 \\
\hline 639 & September 25, 2003 & 9:40:00 AM & 15.80 & 13.99 & 1.21 & 0.60 & 0.60 & 5 \\
\hline 640 & November 6, 2003 & 6:14:00 AM & 15.28 & 13.45 & 1.22 & 0.61 & 0.61 & 5 \\
\hline 641 & July 24, 2003 & 6:06:00 AM & 15.87 & 13.89 & 1.36 & 0.62 & 0.62 & 5 \\
\hline 642 & October 22, 2003 & 7:08:00 PM & 15.32 & 13.67 & 1.03 & 0.62 & 0.62 & 1 \\
\hline 643 & September 9, 2003 & 8:30:00 PM & 15.51 & 13.73 & 1.15 & 0.63 & 0.63 & 1 \\
\hline 644 & June 30,2003 & 10:32:00 PM & 15.56 & 13.65 & 1.28 & 0.63 & 0.63 & 5 \\
\hline 645 & September 7, 2003 & 10:18:00 PM & 15.62 & 13.82 & 1.16 & 0.63 & 0.63 & 5 \\
\hline 646 & April 20, 2003 & 8:42:00 PM & 15.82 & 13.88 & 1.29 & 0.65 & 0.65 & 5 \\
\hline 647 & June 25, 2003 & 9:10:00 PM & 15.32 & 13.53 & 1.13 & 0.66 & 0.66 & 1 \\
\hline 648 & August 11, 2003 & $6: 10: 00$ AM & 15.57 & 13.69 & 1.22 & 0.67 & 0.67 & 1 \\
\hline 649 & August 11, 2003 & 10:14:00 PM & 15.51 & 13.73 & 1.11 & 0.67 & 0.67 & 5 \\
\hline 650 & August 5, 2003 & 5:50:00 AM & 15.38 & 13.57 & 1.13 & 0.68 & 0.68 & 1 \\
\hline 651 & December 7, 2003 & 5:58:00 PM & 15.52 & 13.59 & 1.24 & 0.69 & 0.69 & 5 \\
\hline 652 & August 28, 2003 & 6:00:00 AM & 15.57 & 13.72 & 1.15 & 0.70 & 0.70 & 5 \\
\hline 653 & November 3, 2003 & 7:56:00 AM & 15.39 & 13.51 & 1.17 & 0.71 & 0.71 & 5 \\
\hline 654 & December 8, 2003 & 5:48:00 AM & 15.34 & 13.55 & 1.07 & 0.72 & 0.72 & 1 \\
\hline 655 & May 8, 2003 & $6: 00: 00 \mathrm{AM}$ & 15.83 & 13.83 & 1.28 & 0.72 & 0.72 & 5 \\
\hline 656 & May 1, 2003 & $6: 18: 00$ AM & 15.83 & 13.72 & 1.37 & 0.74 & 0.74 & 5 \\
\hline 657 & September 28, 2003 & 1:06:00 AM & 15.56 & 13.78 & 1.04 & 0.74 & 0.74 & 5 \\
\hline 658 & September 28, 2003 & 1:10:00 AM & 15.56 & 13.78 & 1.04 & 0.74 & 0.74 & 1 \\
\hline 659 & September 28, 2003 & $3: 20: 00$ AM & 15.57 & 13.78 & 1.04 & 0.75 & 0.75 & 1 \\
\hline 660 & June 1, 2003 & 7:28:00 PM & 15.62 & 13.70 & 1.15 & 0.77 & 0.77 & 5 \\
\hline
\end{tabular}




\begin{tabular}{|c|c|c|c|c|c|c|c|c|}
\hline $\begin{array}{l}\text { Record } \\
\text { Number }\end{array}$ & Date of Shipment & $\begin{array}{l}\text { Time of } \\
\text { Shipment }\end{array}$ & $\begin{array}{l}\text { Gross } \\
\text { Value }\end{array}$ & $\begin{array}{l}\text { Background } \\
\text { Measurement }\end{array}$ & $\begin{array}{l}\text { Standard } \\
\text { Deviation }\end{array}$ & Net Exposure & $\begin{array}{l}\text { Adjusted } \\
\text { Net } \\
\text { Exposure }\end{array}$ & $\begin{array}{c}\text { Route } \\
\text { Number }\end{array}$ \\
\hline 661 & August 12, 2003 & $6: 10: 00$ AM & 15.62 & 13.73 & 1.11 & 0.78 & 0.78 & 5 \\
\hline 662 & July 8, 2003 & 11:34:00 PM & 15.57 & 13.71 & 1.07 & 0.79 & 0.79 & 5 \\
\hline 663 & September 17, 2003 & $10: 22: 00 \mathrm{AM}$ & 16.60 & 13.87 & 1.94 & 0.79 & 0.79 & 5 \\
\hline 664 & December 14, 2003 & 4:20:00 PM & 16.33 & 14.08 & 1.45 & 0.80 & 0.80 & 5 \\
\hline 665 & September 25, 2003 & 8:00:00 AM & 16.00 & 13.99 & 1.21 & 0.80 & 0.80 & 1 \\
\hline 666 & October 29, 2003 & 9:26:00 PM & 15.33 & 13.36 & 1.16 & 0.81 & 0.81 & 6 \\
\hline 667 & October 30, 2003 & 7:24:00 AM & 15.33 & 13.36 & 1.16 & 0.81 & 0.81 & 1 \\
\hline 668 & September 19, 2003 & 9:20:00 AM & 15.80 & 13.78 & 1.21 & 0.81 & 0.81 & 5 \\
\hline 669 & August 5, 2003 & 4:00:00 AM & 15.52 & 13.57 & 1.13 & 0.82 & 0.82 & 5 \\
\hline 670 & August 5, 2003 & 6:16:00 AM & 15.52 & 13.57 & 1.13 & 0.82 & 0.82 & 1 \\
\hline 671 & August 22, 2003 & $5: 18: 00 \mathrm{AM}$ & 15.62 & 13.59 & 1.21 & 0.82 & 0.82 & 1 \\
\hline 672 & May 4, 2003 & 9:20:00 PM & 16.12 & 13.70 & 1.60 & 0.82 & 0.82 & 1 \\
\hline 673 & August 20, 2003 & 5:00:00 AM & 17.05 & 14.48 & 1.73 & 0.84 & 0.84 & 5 \\
\hline 674 & September 7, 2003 & 3:44:00 PM & 16.10 & 13.87 & 1.38 & 0.85 & 0.85 & 5 \\
\hline 675 & June 16, 2003 & 7:48:00 PM & 15.81 & 13.78 & 1.17 & 0.86 & 0.86 & 5 \\
\hline 676 & August 5, 2003 & 6:00:00 AM & 15.57 & 13.57 & 1.13 & 0.87 & 0.87 & 1 \\
\hline 677 & April 7, 2003 & 4:42:00 AM & 15.58 & 13.53 & 1.17 & 0.88 & 0.88 & 1 \\
\hline 678 & June 1, 2003 & 2:26:00 PM & 15.75 & 13.70 & 1.15 & 0.90 & 0.90 & 5 \\
\hline 679 & August 10, 2003 & 9:12:00 PM & 15.81 & 13.69 & 1.22 & 0.91 & 0.91 & 5 \\
\hline 680 & July 21,2003 & 9:40:00 PM & 16.31 & 13.91 & 1.49 & 0.91 & 0.91 & 1 \\
\hline 681 & September 25, 2003 & 7:48:00 AM & 16.11 & 13.99 & 1.21 & 0.91 & 0.91 & 1 \\
\hline 682 & August 15, 2003 & 6:36:00 AM & 15.80 & 13.75 & 1.13 & 0.92 & 0.92 & 5 \\
\hline 683 & December 18, 2003 & 6:00:00 AM & 15.53 & 13.40 & 1.18 & 0.95 & 0.95 & 5 \\
\hline 684 & December 18, 2003 & 6:02:00 AM & 15.53 & 13.40 & 1.18 & 0.95 & 0.95 & 5 \\
\hline 685 & November 3, 2003 & $5: 56: 00 \mathrm{AM}$ & 15.83 & 13.48 & 1.40 & 0.95 & 0.95 & 5 \\
\hline 686 & July 10, 2003 & 9:36:00 PM & 15.86 & 13.78 & 1.13 & 0.95 & 0.95 & 5 \\
\hline 687 & October 19, 2003 & 9:28:00 PM & 15.56 & 13.57 & 1.04 & 0.95 & 0.95 & 1 \\
\hline 688 & June 4, 2003 & 7:34:00 AM & 16.11 & 13.91 & 1.20 & 1.00 & 1.00 & 6 \\
\hline 689 & March 17, 2003 & 3:56:00 AM & 16.61 & 13.77 & 1.83 & 1.00 & 1.00 & 5 \\
\hline 690 & May 28, 2003 & 7:00:00 PM & 16.10 & 13.85 & 1.23 & 1.02 & 1.02 & 1 \\
\hline 691 & November 11, 2003 & 6:02:00 PM & 15.63 & 13.46 & 1.12 & 1.05 & 1.05 & 5 \\
\hline 692 & April 9, 2003 & $5: 30: 00 \mathrm{AM}$ & 16.32 & 13.66 & 1.59 & 1.07 & 1.07 & 1 \\
\hline 693 & May 29, 2003 & 5:36:00 AM & 16.04 & 13.76 & 1.16 & 1.12 & 1.12 & 5 \\
\hline
\end{tabular}




\begin{tabular}{|c|c|c|c|c|c|c|c|c|}
\hline $\begin{array}{l}\text { Record } \\
\text { Number }\end{array}$ & Date of Shipment & $\begin{array}{c}\text { Time of } \\
\text { Shipment }\end{array}$ & $\begin{array}{l}\text { Gross } \\
\text { Value }\end{array}$ & $\begin{array}{l}\text { Background } \\
\text { Measurement }\end{array}$ & $\begin{array}{l}\text { Standard } \\
\text { Deviation }\end{array}$ & Net Exposure & $\begin{array}{l}\text { Adjusted } \\
\text { Net } \\
\text { Exposure }\end{array}$ & $\begin{array}{c}\text { Route } \\
\text { Number }\end{array}$ \\
\hline 694 & December 16, 2003 & 8:30:00 PM & 15.64 & 13.30 & 1.22 & 1.12 & 1.12 & 5 \\
\hline 695 & December 15, 2003 & 7:32:00 PM & 15.64 & 13.29 & 1.19 & 1.16 & 1.16 & 5 \\
\hline 696 & July 11, 2003 & 5:48:00 AM & 16.11 & 13.78 & 1.13 & 1.20 & 1.20 & 1 \\
\hline 697 & September 30, 2003 & 11:04:00 AM & 16.28 & 13.82 & 1.24 & 1.22 & 1.22 & 1 \\
\hline 698 & May 21, 2003 & 7:02:00 PM & 16.48 & 13.84 & 1.35 & 1.29 & 1.29 & 1 \\
\hline 699 & August 5, 2003 & 9:34:00 PM & 16.24 & 13.64 & 1.29 & 1.31 & 1.31 & 5 \\
\hline 700 & August 22, 2003 & 5:06:00 AM & 16.11 & 13.59 & 1.21 & 1.31 & 1.31 & 1 \\
\hline 701 & September 28, 2003 & $10: 42: 00$ AM & 16.52 & 13.99 & 1.21 & 1.32 & 1.32 & 5 \\
\hline 702 & July 13, 2003 & 2:30:00 PM & 16.30 & 13.91 & 1.07 & 1.32 & 1.32 & 1 \\
\hline 703 & March 16, 2003 & $10: 24: 00$ AM & 16.30 & 13.77 & 1.21 & 1.32 & 1.32 & 5 \\
\hline 704 & July 23, 2003 & 8:54:00 PM & 16.59 & 13.89 & 1.36 & 1.34 & 1.34 & 5 \\
\hline 705 & May 13, 2003 & 6:02:00 AM & 16.32 & 13.67 & 1.31 & 1.34 & 1.34 & 5 \\
\hline 706 & July 14, 2003 & 5:30:00 AM & 16.24 & 13.75 & 1.13 & 1.36 & 1.36 & 5 \\
\hline 707 & May 16, 2003 & 6:12:00 AM & 16.32 & 13.68 & 1.28 & 1.36 & 1.36 & 5 \\
\hline 708 & March 12, 2003 & 6:08:00 AM & 16.54 & 13.77 & 1.40 & 1.37 & 1.37 & 1 \\
\hline 709 & May 28, 2003 & 10:32:00 PM & 16.31 & 13.76 & 1.16 & 1.39 & 1.39 & 6 \\
\hline 710 & July 6, 2003 & 11:34:00 PM & 16.56 & 13.94 & 1.23 & 1.39 & 1.39 & 5 \\
\hline 711 & August 15, 2003 & $6: 34: 00$ AM & 16.28 & 13.75 & 1.13 & 1.40 & 1.40 & 5 \\
\hline 712 & May 21, 2003 & 7:04:00 PM & 16.59 & 13.84 & 1.35 & 1.40 & 1.40 & 1 \\
\hline 713 & May 7, 2003 & 8:12:00 PM & 16.52 & 13.83 & 1.28 & 1.41 & 1.41 & 5 \\
\hline 714 & July 24, 2003 & $6: 14: 00$ AM & 16.76 & 13.89 & 1.36 & 1.51 & 1.51 & 1 \\
\hline 715 & March 12, 2003 & 6:14:00 AM & 16.77 & 13.77 & 1.40 & 1.60 & 1.60 & 1 \\
\hline 716 & May 6, 2003 & 8:12:00 PM & 16.60 & 13.73 & 1.27 & 1.60 & 1.60 & 5 \\
\hline 717 & July 1, 2003 & 7:46:00 AM & 16.60 & 13.80 & 1.19 & 1.61 & 1.61 & 1 \\
\hline 718 & May 7, 2003 & 8:18:00 PM & 16.73 & 13.83 & 1.28 & 1.62 & 1.62 & 5 \\
\hline 719 & April 29, 2003 & 6:12:00 PM & 16.76 & 13.71 & 1.32 & 1.72 & 1.72 & 1 \\
\hline 720 & September 28, 2003 & 3:52:00 PM & 16.96 & 13.99 & 1.21 & 1.76 & 1.76 & 1 \\
\hline 721 & April 1, 2003 & 10:44:00 PM & 17.10 & 13.87 & 1.46 & 1.77 & 1.77 & 5 \\
\hline 722 & April 28, 2003 & 2:16:00 AM & 16.61 & 13.68 & 1.15 & 1.78 & 1.78 & 1 \\
\hline 723 & September 14, 2003 & 6:24:00 PM & 17.08 & 13.77 & 1.52 & 1.79 & 1.79 & 5 \\
\hline 724 & September 29, 2003 & 5:44:00 AM & 18.31 & 13.97 & 2.51 & 1.83 & 1.83 & 5 \\
\hline 725 & July 14, 2003 & 5:36:00 AM & 16.72 & 13.75 & 1.13 & 1.84 & 1.84 & 1 \\
\hline 726 & April 1, 2003 & 2:14:00 PM & 16.80 & 13.71 & 1.23 & 1.86 & 1.86 & 1 \\
\hline
\end{tabular}




\begin{tabular}{|c|c|c|c|c|c|c|c|c|}
\hline $\begin{array}{l}\text { Record } \\
\text { Number }\end{array}$ & Date of Shipment & $\begin{array}{l}\text { Time of } \\
\text { Shipment }\end{array}$ & $\begin{array}{l}\text { Gross } \\
\text { Value }\end{array}$ & $\begin{array}{l}\text { Background } \\
\text { Measurement }\end{array}$ & $\begin{array}{l}\text { Standard } \\
\text { Deviation }\end{array}$ & Net Exposure & $\begin{array}{l}\text { Adjusted } \\
\text { Net } \\
\text { Exposure }\end{array}$ & $\begin{array}{c}\text { Route } \\
\text { Number }\end{array}$ \\
\hline 727 & August 28, 2003 & 6:02:00 AM & 16.73 & 13.72 & 1.15 & 1.86 & 1.86 & 5 \\
\hline 728 & June 30, 2003 & 10:30:00 PM & 16.80 & 13.65 & 1.28 & 1.87 & 1.87 & 6 \\
\hline 729 & October 1, 2003 & 6:56:00 AM & 16.81 & 13.74 & 1.19 & 1.88 & 1.88 & 5 \\
\hline 730 & May 21, 2003 & 6:00:00 AM & 16.98 & 13.73 & 1.37 & 1.88 & 1.88 & 1 \\
\hline 731 & July 22,2003 & 6:00:00 AM & 17.30 & 13.91 & 1.49 & 1.90 & 1.90 & 1 \\
\hline 732 & June 17, 2003 & 5:48:00 AM & 16.81 & 13.73 & 1.16 & 1.92 & 1.92 & 1 \\
\hline 733 & April 10, 2003 & 7:12:00 PM & 17.05 & 13.73 & 1.38 & 1.94 & 1.94 & 5 \\
\hline 734 & May 12, 2003 & 10:00:00 PM & 17.05 & 13.67 & 1.31 & 2.07 & 2.07 & 5 \\
\hline 735 & July 27, 2003 & 8:02:00 PM & 16.99 & 13.77 & 1.13 & 2.09 & 2.09 & 5 \\
\hline 736 & November 25, 2003 & 5:02:00 AM & 16.99 & 13.75 & 1.11 & 2.13 & 2.13 & 1 \\
\hline 737 & July 7,2003 & 7:00:00 AM & 17.33 & 13.94 & 1.23 & 2.16 & 2.16 & 5 \\
\hline 738 & May 5, 2003 & $6: 10: 00 \mathrm{AM}$ & 17.46 & 13.70 & 1.60 & 2.16 & 2.16 & 1 \\
\hline 739 & November 25, 2003 & 5:00:00 AM & 17.03 & 13.75 & 1.11 & 2.17 & 2.17 & 1 \\
\hline 740 & July 9,2003 & $6: 10: 00 \mathrm{AM}$ & 17.05 & 13.71 & 1.07 & 2.27 & 2.27 & 1 \\
\hline 741 & February 19, 2003 & 10:34:00 PM & 17.56 & 13.90 & 1.38 & 2.28 & 2.28 & 1 \\
\hline 742 & August 22, 2003 & 7:42:00 AM & 17.09 & 13.59 & 1.21 & 2.29 & 2.29 & 1 \\
\hline 743 & October 23, 2003 & 6:00:00 AM & 17.22 & 13.62 & 1.29 & 2.31 & 2.31 & 5 \\
\hline 744 & September 19, 2003 & 9:18:00 AM & 17.30 & 13.78 & 1.21 & 2.31 & 2.31 & 1 \\
\hline 745 & April 7, 2003 & $11: 32: 00 \mathrm{AM}$ & 16.97 & 13.56 & 1.08 & 2.33 & 2.33 & 1 \\
\hline 746 & October 8, 2003 & $6: 20: 00$ AM & 17.97 & 13.88 & 1.72 & 2.37 & 2.37 & 1 \\
\hline 747 & December 3, 2003 & 6:00:00 AM & 17.10 & 13.46 & 1.26 & 2.38 & 2.38 & 1 \\
\hline 748 & May 8, 2003 & 1:58:00 PM & 17.30 & 13.65 & 1.23 & 2.42 & 2.42 & 5 \\
\hline 749 & June 17, 2003 & $5: 26: 00$ AM & 17.33 & 13.73 & 1.16 & 2.44 & 2.44 & 5 \\
\hline 750 & September 19, 2003 & 9:08:00 AM & 17.46 & 13.78 & 1.21 & 2.47 & 2.47 & 5 \\
\hline 751 & August 12, 2003 & $6: 20: 00 \mathrm{AM}$ & 17.33 & 13.73 & 1.11 & 2.49 & 2.49 & 5 \\
\hline 752 & May 1, 2003 & 6:04:00 AM & 17.73 & 13.72 & 1.37 & 2.64 & 2.64 & 1 \\
\hline 753 & February 24, 2003 & 1:42:00 AM & 17.71 & 13.85 & 1.17 & 2.69 & 2.69 & 1 \\
\hline 754 & November 3, 2003 & 5:46:00 AM & 17.59 & 13.48 & 1.40 & 2.71 & 2.71 & 5 \\
\hline 755 & April 28, 2003 & $6: 10: 00 \mathrm{AM}$ & 17.58 & 13.68 & 1.15 & 2.75 & 2.75 & 1 \\
\hline 756 & December 14, 2003 & 5:14:00 AM & 17.51 & 13.57 & 1.11 & 2.83 & 2.83 & 5 \\
\hline 757 & June 1,2003 & 7:42:00 PM & 17.79 & 13.70 & 1.15 & 2.94 & 2.94 & 5 \\
\hline 758 & August 2, 2003 & 8:42:00 PM & 17.79 & 13.59 & 1.25 & 2.95 & 2.95 & 5 \\
\hline 759 & September 21, 2003 & 5:56:00 PM & 17.93 & 13.90 & 1.07 & 2.96 & 2.96 & 1 \\
\hline
\end{tabular}




\begin{tabular}{|c|c|c|c|c|c|c|c|c|}
\hline $\begin{array}{l}\text { Record } \\
\text { Number }\end{array}$ & Date of Shipment & $\begin{array}{l}\text { Time of } \\
\text { Shipment }\end{array}$ & $\begin{array}{l}\text { Gross } \\
\text { Value }\end{array}$ & $\begin{array}{l}\text { Background } \\
\text { Measurement }\end{array}$ & $\begin{array}{l}\text { Standard } \\
\text { Deviation }\end{array}$ & Net Exposure & $\begin{array}{l}\text { Adjusted } \\
\text { Net } \\
\text { Exposure }\end{array}$ & $\begin{array}{c}\text { Route } \\
\text { Number }\end{array}$ \\
\hline 760 & April 8, 2003 & 5:38:00 PM & 18.04 & 13.62 & 1.38 & 3.04 & 3.04 & 5 \\
\hline 761 & October 8, 2003 & 8:26:00 PM & 18.55 & 13.89 & 1.54 & 3.12 & 3.12 & 5 \\
\hline 762 & August 11, 2003 & 5:28:00 AM & 18.04 & 13.69 & 1.22 & 3.14 & 3.14 & 1 \\
\hline 763 & September 15, 2003 & 6:34:00 AM & 18.31 & 13.70 & 1.36 & 3.25 & 3.25 & 1 \\
\hline 764 & October 15, 2003 & 7:48:00 AM & 18.30 & 13.82 & 1.17 & 3.31 & 3.31 & 1 \\
\hline 765 & July 10, 2003 & 6:34:00 PM & 18.42 & 13.91 & 1.15 & 3.36 & 3.36 & 5 \\
\hline 766 & August 15, 2003 & 6:30:00 AM & 18.31 & 13.75 & 1.13 & 3.43 & 3.43 & 5 \\
\hline 767 & April 29, 2003 & 10:52:00 PM & 19.64 & 13.82 & 2.36 & 3.46 & 3.46 & 5 \\
\hline 768 & April 17, 2003 & 5:36:00 AM & 18.44 & 13.68 & 1.20 & 3.55 & 3.55 & 1 \\
\hline 769 & February 24, 2003 & 5:52:00 AM & 18.69 & 13.85 & 1.17 & 3.67 & 3.67 & 1 \\
\hline 770 & October 15, 2003 & 7:50:00 AM & 18.69 & 13.82 & 1.17 & 3.70 & 3.70 & 2 \\
\hline 771 & December 15, 2003 & 7:28:00 PM & 18.20 & 13.29 & 1.19 & 3.72 & 3.72 & 5 \\
\hline 772 & September 12, 2003 & $6: 28: 00$ AM & 20.03 & 13.80 & 2.48 & 3.75 & 3.75 & 5 \\
\hline 773 & August 27, 2003 & 9:40:00 PM & 18.78 & 13.72 & 1.15 & 3.91 & 3.91 & 5 \\
\hline 774 & April 23, 2003 & 5:12:00 AM & 20.04 & 14.03 & 2.05 & 3.96 & 3.96 & 5 \\
\hline 775 & September 24, 2003 & 7:24:00 PM & 19.15 & 13.97 & 1.14 & 4.04 & 4.04 & 2 \\
\hline 776 & August 5, 2003 & 6:18:00 AM & 18.79 & 13.57 & 1.13 & 4.09 & 4.09 & 1 \\
\hline 777 & April 6, 2003 & 8:18:00 PM & 19.04 & 13.53 & 1.17 & 4.34 & 4.34 & 1 \\
\hline 778 & October 29, 2003 & 7:06:00 AM & 19.29 & 13.54 & 1.24 & 4.51 & 4.51 & 1 \\
\hline 779 & April 14, 2003 & 4:58:00 AM & 20.86 & 13.61 & 2.66 & 4.59 & 4.59 & 5 \\
\hline 780 & December 10, 2003 & 7:44:00 PM & 19.41 & 13.58 & 1.23 & 4.60 & 4.60 & 5 \\
\hline 781 & August 4, 2003 & $7: 22: 00 \mathrm{AM}$ & 19.53 & 13.64 & 1.22 & 4.67 & 4.67 & 1 \\
\hline 782 & March 17, 2003 & 6:06:00 AM & 20.38 & 13.77 & 1.83 & 4.77 & 4.77 & 1 \\
\hline 783 & November 20, 2003 & 5:00:00 AM & 19.55 & 13.46 & 1.25 & 4.84 & 4.84 & 5 \\
\hline 784 & August 19, 2003 & 4:06:00 AM & 20.01 & 13.86 & 1.31 & 4.84 & 4.84 & 1 \\
\hline 785 & September 3, 2003 & $7: 30: 00 \mathrm{AM}$ & 20.02 & 13.66 & 1.29 & 5.07 & 5.07 & 5 \\
\hline 786 & July 15,2003 & 5:52:00 AM & 22.26 & 13.90 & 3.26 & 5.10 & 5.10 & 5 \\
\hline 787 & August 13, 2003 & 5:58:00 AM & 20.02 & 13.68 & 1.14 & 5.20 & 5.20 & 1 \\
\hline 788 & June 24, 2003 & 7:24:00 AM & 20.27 & 13.77 & 1.27 & 5.23 & 5.23 & 5 \\
\hline 789 & September 21, 2003 & 8:16:00 PM & 21.33 & 13.84 & 1.96 & 5.53 & 5.53 & 5 \\
\hline 790 & July 24,2003 & 7:48:00 AM & 20.76 & 13.90 & 1.16 & 5.70 & 5.70 & 1 \\
\hline 791 & July 28, 2003 & 5:30:00 AM & 20.60 & 13.77 & 1.13 & 5.70 & 5.70 & 5 \\
\hline 792 & October 20, 2003 & 1:00:00 PM & 20.36 & 13.57 & 1.04 & 5.75 & 5.75 & 1 \\
\hline
\end{tabular}




\begin{tabular}{|c|c|c|c|c|c|c|c|c|}
\hline $\begin{array}{l}\text { Record } \\
\text { Number }\end{array}$ & Date of Shipment & $\begin{array}{l}\text { Time of } \\
\text { Shipment }\end{array}$ & $\begin{array}{l}\text { Gross } \\
\text { Value }\end{array}$ & $\begin{array}{l}\text { Background } \\
\text { Measurement }\end{array}$ & $\begin{array}{l}\text { Standard } \\
\text { Deviation }\end{array}$ & Net Exposure & $\begin{array}{l}\text { Adjusted } \\
\text { Net } \\
\text { Exposure }\end{array}$ & $\begin{array}{c}\text { Route } \\
\text { Number }\end{array}$ \\
\hline 793 & May 18, 2003 & 6:38:00 PM & 20.84 & 13.80 & 1.20 & 5.84 & 5.84 & 1 \\
\hline 794 & November 6, 2003 & 3:06:00 AM & 20.86 & 13.45 & 1.22 & 6.19 & 6.19 & 5 \\
\hline 795 & April 8, 2003 & 9:14:00 PM & 21.76 & 13.66 & 1.59 & 6.51 & 6.51 & 5 \\
\hline 796 & July 17, 2003 & 5:38:00 AM & 21.33 & 13.72 & 1.07 & 6.54 & 6.54 & 1 \\
\hline 797 & July 22, 2003 & 2:24:00 AM & 22.45 & 13.91 & 1.49 & 7.05 & 7.05 & 5 \\
\hline 798 & November 20, 2003 & 4:58:00 AM & 22.23 & 13.46 & 1.25 & 7.52 & 7.52 & 1 \\
\hline 799 & November 4, 2003 & 8:46:00 AM & 22.57 & 13.49 & 1.31 & 7.77 & 7.77 & 1 \\
\hline 800 & May 12, 2003 & 6:26:00 PM & 24.48 & 13.75 & 2.14 & 8.59 & 8.59 & 1 \\
\hline 801 & November 8, 2003 & 8:44:00 AM & 23.48 & 13.50 & 1.25 & 8.73 & 8.73 & 1 \\
\hline 802 & May 18, 2003 & 6:40:00 PM & 23.75 & 13.80 & 1.20 & 8.75 & 8.75 & 5 \\
\hline 803 & April 17, 2003 & 5:38:00 AM & 23.72 & 13.68 & 1.20 & 8.83 & 8.83 & 2 \\
\hline 804 & May 1, 2003 & 3:02:00 AM & 23.94 & 13.72 & 1.37 & 8.85 & 8.85 & 5 \\
\hline 805 & June 20, 2003 & 3:20:00 AM & 25.46 & 13.99 & 2.58 & 8.89 & 8.89 & 1 \\
\hline 806 & December 15, 2003 & 7:30:00 PM & 23.78 & 13.29 & 1.19 & 9.30 & 9.30 & 5 \\
\hline 807 & August 28, 2003 & 6:06:00 AM & 24.49 & 13.72 & 1.15 & 9.62 & 9.62 & 6 \\
\hline 808 & June 23,2003 & 6:12:00 PM & 25.13 & 13.92 & 1.43 & 9.78 & 9.78 & 5 \\
\hline 809 & April 17, 2003 & 6:08:00 AM & 24.68 & 13.68 & 1.20 & 9.79 & 9.79 & 1 \\
\hline 810 & June 15, 2003 & 9:34:00 AM & 25.20 & 13.88 & 1.23 & 10.09 & 10.09 & 6 \\
\hline 811 & December 7, 2003 & 4:48:00 PM & 25.22 & 13.59 & 1.24 & 10.39 & 10.39 & 1 \\
\hline 812 & February 18, 2003 & 6:30:00 AM & 25.17 & 13.42 & 1.16 & 10.59 & 10.59 & 1 \\
\hline 813 & December 18, 2003 & 4:10:00 AM & 25.23 & 13.40 & 1.18 & 10.65 & 10.65 & 1 \\
\hline 814 & May 5, 2003 & 3:24:00 AM & 26.19 & 13.70 & 1.60 & 10.89 & 10.89 & 5 \\
\hline 815 & May 5, 2003 & 6:16:00 AM & 28.03 & 13.70 & 1.60 & 12.73 & 12.73 & 1 \\
\hline 816 & April 7, 2003 & 5:30:00 AM & 27.46 & 13.53 & 1.17 & 12.76 & 12.76 & 1 \\
\hline 817 & May 4, 2003 & 6:22:00 PM & 28.81 & 13.73 & 1.93 & 13.15 & 13.15 & 2 \\
\hline 818 & April 9, 2003 & 5:28:00 AM & 28.69 & 13.66 & 1.59 & 13.44 & 13.44 & 1 \\
\hline 819 & May 5, 2003 & 8:30:00 AM & 28.37 & 13.72 & 1.21 & 13.44 & 13.44 & 5 \\
\hline 820 & April 13, 2003 & 1:48:00 PM & 28.81 & 13.55 & 1.25 & 14.01 & 14.01 & 5 \\
\hline 821 & May 5, 2003 & 3:20:00 AM & 29.55 & 13.70 & 1.60 & 14.25 & 14.25 & 2 \\
\hline 822 & February 23, 2003 & 7:24:00 PM & 30.90 & 13.83 & 1.96 & 15.12 & 15.12 & 1 \\
\hline 823 & May 1, 2003 & 3:04:00 AM & 30.29 & 13.72 & 1.37 & 15.20 & 15.20 & 1 \\
\hline 824 & May 5, 2003 & 8:36:00 AM & 31.28 & 13.72 & 1.21 & 16.35 & 16.35 & 2 \\
\hline 825 & March 17, 2003 & 6:08:00 AM & 32.59 & 13.77 & 1.83 & 16.98 & 16.98 & 1 \\
\hline
\end{tabular}




\begin{tabular}{|c|c|c|c|c|c|c|c|c|}
\hline $\begin{array}{l}\text { Record } \\
\text { Number }\end{array}$ & Date of Shipment & $\begin{array}{l}\text { Time of } \\
\text { Shipment }\end{array}$ & $\begin{array}{l}\text { Gross } \\
\text { Value }\end{array}$ & $\begin{array}{l}\text { Background } \\
\text { Measurement }\end{array}$ & $\begin{array}{l}\text { Standard } \\
\text { Deviation }\end{array}$ & Net Exposure & $\begin{array}{l}\text { Adjusted } \\
\text { Net } \\
\text { Exposure } \\
\end{array}$ & $\begin{array}{c}\text { Route } \\
\text { Number }\end{array}$ \\
\hline 826 & October 12, 2003 & $3: 46: 00$ PM & 35.38 & 14.15 & 4.16 & 17.07 & 17.07 & 5 \\
\hline 827 & July 1,2003 & 7:10:00 PM & 33.18 & 13.80 & 1.19 & 18.19 & 18.19 & 5 \\
\hline 828 & October 9, 2003 & 5:04:00 AM & 33.70 & 13.89 & 1.54 & 18.27 & 18.27 & 5 \\
\hline 829 & November 17, 2003 & 4:20:00 AM & 36.40 & 13.74 & 4.08 & 18.58 & 18.58 & 6 \\
\hline 830 & July 22,2003 & $5: 52: 00$ AM & 35.39 & 13.91 & 1.49 & 19.99 & 19.99 & 6 \\
\hline 831 & November 6, 2003 & $6: 12: 00$ AM & 35.18 & 13.45 & 1.22 & 20.51 & 20.51 & 6 \\
\hline 832 & August 10, 2003 & 1:00:00 PM & 37.80 & 13.75 & 1.51 & 22.55 & 22.55 & 2 \\
\hline 833 & August 25, 2003 & 6:04:00 PM & 38.78 & 13.84 & 2.00 & 22.94 & 22.94 & 2 \\
\hline 834 & October 6, 2003 & $1: 24: 00$ AM & 38.56 & 13.75 & 1.47 & 23.34 & 23.34 & 6 \\
\hline 835 & August 20, 2003 & 10:38:00 AM & 45.64 & 13.97 & 7.01 & 24.66 & 24.66 & 6 \\
\hline 836 & May 4, 2003 & 3:04:00 PM & 40.97 & 13.73 & 1.93 & 25.31 & 25.31 & 6 \\
\hline 837 & October 23, 2003 & $5: 50: 00 \mathrm{AM}$ & 43.96 & 13.62 & 1.29 & 29.05 & 29.05 & 1 \\
\hline 838 & September 4, 2003 & 4:50:00 AM & 48.24 & 13.89 & 3.84 & 30.51 & 30.51 & 2 \\
\hline 839 & September 1, 2003 & 2:40:00 PM & 48.80 & 13.96 & 3.15 & 31.69 & 31.69 & 6 \\
\hline 840 & July 24,2003 & 6:04:00 AM & 47.36 & 13.89 & 1.36 & 32.11 & 32.11 & 6 \\
\hline 841 & March 2, 2003 & 12:18:00 PM & 47.87 & 13.54 & 2.00 & 32.33 & 32.33 & 6 \\
\hline 842 & March 31, 2003 & 2:12:00 AM & 53.49 & 13.87 & 6.95 & 32.67 & 32.67 & 2 \\
\hline 843 & July 24, 2003 & $6: 02: 00 \mathrm{AM}$ & 50.18 & 13.89 & 1.36 & 34.93 & 34.93 & 6 \\
\hline 844 & March 9, 2003 & 10:38:00 AM & 52.89 & 13.52 & 1.63 & 37.74 & 37.74 & 5 \\
\hline 845 & August 20, 2003 & $12: 44: 00$ AM & 54.92 & 14.48 & 1.73 & 38.71 & 38.71 & 6 \\
\hline 846 & October 26, 2003 & 6:22:00 PM & 54.30 & 13.49 & 1.40 & 39.41 & 39.41 & 5 \\
\hline 847 & March 9, 2003 & 10:36:00 AM & 55.12 & 13.52 & 1.63 & 39.97 & 39.97 & 6 \\
\hline 848 & August 11, 2003 & 1:48:00 AM & 55.40 & 13.69 & 1.22 & 40.50 & 40.50 & 2 \\
\hline 849 & August 21, 2003 & 8:48:00 AM & 56.14 & 13.65 & 1.93 & 40.56 & 40.56 & 6 \\
\hline 850 & August 20, 2003 & 5:02:00 PM & 62.04 & 13.97 & 7.01 & 41.06 & 41.06 & 6 \\
\hline 851 & April 3, 2003 & 12:40:00 PM & 57.14 & 13.67 & 1.86 & 41.61 & 41.61 & 6 \\
\hline 852 & October 19, 2003 & 5:50:00 PM & 57.82 & 13.63 & 1.21 & 42.98 & 42.98 & 6 \\
\hline 853 & July 22, 2003 & $12: 28: 00$ AM & 58.56 & 13.91 & 1.49 & 43.16 & 43.16 & 6 \\
\hline 854 & September 6, 2003 & 9:02:00 PM & 61.08 & 13.92 & 2.51 & 44.65 & 44.65 & 6 \\
\hline 855 & October 14, 2003 & $6: 54: 00 \mathrm{AM}$ & 62.28 & 13.85 & 3.57 & 44.86 & 44.86 & 6 \\
\hline 856 & September 14, 2003 & 3:02:00 PM & 62.26 & 13.77 & 1.52 & 46.97 & 46.97 & 6 \\
\hline 857 & August 11, 2003 & 4:54:00 AM & 62.00 & 13.69 & 1.22 & 47.10 & 47.10 & 6 \\
\hline 858 & August 10, 2003 & 12:04:00 PM & 62.76 & 13.75 & 1.51 & 47.51 & 47.51 & 6 \\
\hline
\end{tabular}




\begin{tabular}{|c|c|c|c|c|c|c|c|c|}
\hline $\begin{array}{l}\text { Record } \\
\text { Number }\end{array}$ & Date of Shipment & $\begin{array}{c}\text { Time of } \\
\text { Shipment }\end{array}$ & $\begin{array}{l}\text { Gross } \\
\text { Value }\end{array}$ & $\begin{array}{l}\text { Background } \\
\text { Measurement }\end{array}$ & $\begin{array}{l}\text { Standard } \\
\text { Deviation }\end{array}$ & Net Exposure & $\begin{array}{l}\text { Adjusted } \\
\text { Net } \\
\text { Exposure }\end{array}$ & $\begin{array}{c}\text { Route } \\
\text { Number }\end{array}$ \\
\hline 859 & September 12, 2003 & 1:30:00 AM & 67.17 & 13.80 & 2.48 & 50.89 & 50.89 & 6 \\
\hline 860 & December 14, 2003 & 4:54:00 PM & 68.16 & 14.08 & 1.45 & 52.63 & 52.63 & 6 \\
\hline 861 & August 15, 2003 & 9:30:00 PM & 68.34 & 13.63 & 1.22 & 53.49 & 53.49 & 2 \\
\hline 862 & November 9, 2003 & 6:30:00 AM & 69.71 & 13.50 & 1.75 & 54.46 & 54.46 & 6 \\
\hline 863 & August 15, 2003 & 6:00:00 AM & 71.00 & 13.75 & 1.13 & 56.12 & 56.12 & 2 \\
\hline 864 & October 18, 2003 & 4:14:00 PM & 73.20 & 13.87 & 3.10 & 56.23 & 56.23 & 5 \\
\hline 865 & November 20, 2003 & 7:36:00 AM & 71.3 & 13.46 & 1.25 & 56.59 & 56.59 & 5 \\
\hline 866 & July 27,2003 & 5:58:00 PM & 73.00 & 13.83 & 1.15 & 58.02 & 58.02 & 2 \\
\hline 867 & September 8, 2003 & 5:58:00 PM & 76.60 & 13.96 & 3.35 & 59.29 & 59.29 & 6 \\
\hline 868 & October 14, 2003 & 7:32:00 AM & 76.90 & 13.85 & 3.57 & 59.48 & 59.48 & 6 \\
\hline 869 & December 8, 2003 & 5:46:00 AM & 74.70 & 13.55 & 1.07 & 60.08 & 60.08 & 6 \\
\hline 870 & November 17, 2003 & 1:30:00 AM & 78.10 & 13.74 & 4.08 & 60.28 & 60.28 & 6 \\
\hline 871 & August 24,2003 & 2:32:00 PM & 75.80 & 13.73 & 1.12 & 60.95 & 60.95 & 1 \\
\hline 872 & September 11, 2003 & $6: 56: 00 \mathrm{AM}$ & 79.90 & 13.90 & 4.68 & 61.32 & 61.32 & 1 \\
\hline 873 & August 20, 2003 & $10: 34: 00$ AM & 82.40 & 13.97 & 7.01 & 61.42 & 61.42 & 1 \\
\hline 874 & August 21, 2003 & 6:46:00 AM & 77.60 & 13.63 & 1.99 & 61.98 & 61.98 & 1 \\
\hline 875 & November 23, 2003 & 5:46:00 PM & 77.20 & 13.15 & 1.16 & 62.89 & 62.89 & 1 \\
\hline 876 & September 22, 2003 & 9:28:00 AM & 80.50 & 14.07 & 3.22 & 63.21 & 63.21 & 6 \\
\hline 877 & November 12, 2003 & $6: 20: 00$ AM & 79.60 & 13.55 & 1.35 & 64.70 & 64.70 & 6 \\
\hline 878 & November 10, 2003 & 2:06:00 AM & 80.60 & 13.52 & 2.32 & 64.76 & 64.76 & 6 \\
\hline 879 & October 21, 2003 & 7:12:00 AM & 82.80 & 13.75 & 2.77 & 66.28 & 66.28 & 6 \\
\hline 880 & September 21, 2003 & 5:58:00 PM & 83.90 & 13.90 & 1.07 & 68.93 & 68.93 & 6 \\
\hline 881 & September 1, 2003 & 2:44:00 PM & 87.10 & 13.96 & 3.15 & 69.99 & 69.99 & 6 \\
\hline 882 & September 29, 2003 & 5:38:00 AM & 87.50 & 13.97 & 2.51 & 71.02 & 71.02 & 6 \\
\hline 883 & September 4, 2003 & $6: 56: 00$ AM & 90.50 & 13.89 & 3.84 & 72.77 & 72.77 & 1 \\
\hline 884 & September 2, 2003 & 6:32:00 AM & 92.20 & 14.13 & 4.96 & 73.11 & 73.11 & 6 \\
\hline 885 & August 18, 2003 & 7:22:00 AM & 93.70 & 14.19 & 5.25 & 74.26 & 74.26 & 6 \\
\hline 886 & November 25, 2003 & 5:08:00 AM & 89.9 & 13.75 & 1.11 & 75.04 & 75.04 & 1 \\
\hline 887 & September 10, 2003 & 10:10:00 AM & 95.30 & 14.19 & 5.72 & 75.39 & 75.39 & 6 \\
\hline 888 & August 26, 2003 & 5:58:00 AM & 95.70 & 14.33 & 4.58 & 76.79 & 76.79 & 6 \\
\hline 889 & April 6, 2003 & 1:16:00 PM & 93.80 & 13.68 & 1.25 & 78.87 & 78.87 & 6 \\
\hline 890 & September 9, 2003 & 7:50:00 AM & 94.70 & 13.90 & 1.48 & 79.32 & 79.32 & 1 \\
\hline 891 & April 8, 2003 & 2:28:00 AM & 94.10 & 13.42 & 1.04 & 79.64 & 79.64 & 6 \\
\hline
\end{tabular}




\begin{tabular}{|c|c|c|c|c|c|c|c|c|}
\hline $\begin{array}{l}\text { Record } \\
\text { Number }\end{array}$ & Date of Shipment & $\begin{array}{l}\text { Time of } \\
\text { Shipment }\end{array}$ & $\begin{array}{l}\text { Gross } \\
\text { Value }\end{array}$ & $\begin{array}{l}\text { Background } \\
\text { Measurement }\end{array}$ & $\begin{array}{l}\text { Standard } \\
\text { Deviation }\end{array}$ & Net Exposure & $\begin{array}{l}\text { Adjusted } \\
\text { Net } \\
\text { Exposure }\end{array}$ & $\begin{array}{c}\text { Route } \\
\text { Number }\end{array}$ \\
\hline 892 & October 12, 2003 & $2: 28: 00$ PM & 100.50 & 14.15 & 4.16 & 82.19 & 82.19 & 6 \\
\hline 893 & September 6, 2003 & 3:34:00 PM & 100.80 & 13.93 & 3.53 & 83.34 & 83.34 & 6 \\
\hline 894 & April 3, 2003 & 3:38:00 AM & 100.00 & 13.68 & 1.36 & 84.96 & 84.96 & 6 \\
\hline 895 & June 19, 2003 & 7:44:00 AM & 100.80 & 13.90 & 1.50 & 85.40 & 85.40 & 6 \\
\hline 896 & September 3, 2003 & 6:18:00 AM & 100.40 & 13.66 & 1.29 & 85.45 & 85.45 & 6 \\
\hline 897 & July 27, 2003 & 12:30:00 PM & 100.80 & 13.83 & 1.15 & 85.82 & 85.82 & 6 \\
\hline 898 & September 2, 2003 & 7:20:00 AM & 105.20 & 14.13 & 4.96 & 86.11 & 86.11 & 6 \\
\hline 899 & August 14, 2003 & 5:08:00 AM & 107.70 & 13.81 & 4.23 & 89.66 & 89.66 & 6 \\
\hline 900 & April 8, 2003 & 2:24:00 AM & 105.30 & 13.42 & 1.04 & 90.84 & 90.84 & 6 \\
\hline 901 & September 22, 2003 & 7:00:00 AM & 107.40 & 13.84 & 1.96 & 91.60 & 91.60 & 2 \\
\hline 902 & September 10, 2003 & 9:36:00 PM & 110.40 & 13.90 & 4.68 & 91.82 & 91.82 & 5 \\
\hline 903 & September 22, 2003 & 7:02:00 AM & 111.30 & 13.84 & 1.96 & 95.50 & 95.50 & 6 \\
\hline 904 & November 13, 2003 & 4:36:00 AM & 120.70 & 13.89 & 4.37 & 102.44 & 102.44 & 6 \\
\hline 905 & April 20, 2003 & 3:50:00 PM & 126.20 & 13.93 & 4.28 & 107.99 & 107.99 & 1 \\
\hline 906 & April 13, 2003 & $12: 56: 00 \mathrm{AM}$ & 126.00 & 13.59 & 1.43 & 110.98 & 110.98 & 1 \\
\hline 907 & April 6, 2003 & 3:18:00 AM & 129.00 & 13.70 & 1.50 & 113.80 & 113.80 & 6 \\
\hline 908 & May 21, 2003 & 2:58:00 PM & 139.10 & 13.84 & 1.35 & 123.91 & 123.91 & 6 \\
\hline 909 & March 31, 2003 & 3:28:00 AM & 146.00 & 13.87 & 6.95 & 125.18 & 125.18 & 5 \\
\hline 910 & August 13, 2003 & $10: 46: 00 \mathrm{AM}$ & 150.00 & 13.72 & 1.18 & 135.11 & 135.11 & 6 \\
\hline 911 & April 29, 2003 & 6:02:00 AM & 173.90 & 13.75 & 1.37 & 158.78 & 158.78 & 6 \\
\hline 912 & August 26, 2003 & 7:32:00 AM & 178.90 & 14.33 & 4.58 & 159.99 & 159.99 & 5 \\
\hline 913 & August 26, 2003 & 7:34:00 AM & 183.30 & 14.33 & 4.58 & 164.39 & 164.39 & 1 \\
\hline 914 & September 3, 2003 & 4:42:00 AM & 183.30 & 13.66 & 1.29 & 168.35 & 168.35 & 1 \\
\hline 915 & March 30, 2003 & 4:18:00 AM & 192.40 & 13.62 & 8.17 & 170.61 & 170.61 & 1 \\
\hline 916 & August 11, 2003 & 4:46:00 AM & 186.60 & 13.69 & 1.22 & 171.70 & 171.70 & 1 \\
\hline 917 & September 3, 2003 & 4:36:00 AM & 197.10 & 13.66 & 1.29 & 182.15 & 182.15 & 1 \\
\hline 918 & May 21, 2003 & 3:06:00 PM & 205.40 & 13.84 & 1.35 & 190.21 & 190.21 & 1 \\
\hline 919 & July 28, 2003 & 1:18:00 AM & 220.80 & 13.77 & 1.13 & 205.90 & 205.90 & 6 \\
\hline 920 & September 9, 2003 & 3:22:00 AM & 223.50 & 13.81 & 1.41 & 208.29 & 208.29 & 1 \\
\hline 921 & July 28, 2003 & 1:20:00 AM & 223.40 & 13.77 & 1.13 & 208.50 & 208.50 & 1 \\
\hline 922 & April 17, 2003 & 2:34:00 AM & 233.40 & 13.68 & 1.20 & 218.51 & 218.51 & 1 \\
\hline 923 & May 20, 2003 & $12: 22: 00 \mathrm{AM}$ & 248.10 & 13.72 & 1.50 & 232.88 & 232.88 & 6 \\
\hline 924 & June 29, 2003 & 10:54:00 PM & 254.80 & 13.71 & 1.34 & 239.74 & 239.74 & 6 \\
\hline
\end{tabular}




\begin{tabular}{|c|c|c|c|c|c|c|c|c|}
\hline $\begin{array}{l}\text { Record } \\
\text { Number }\end{array}$ & Date of Shipment & $\begin{array}{l}\text { Time of } \\
\text { Shipment }\end{array}$ & $\begin{array}{l}\text { Gross } \\
\text { Value }\end{array}$ & $\begin{array}{l}\text { Background } \\
\text { Measurement }\end{array}$ & $\begin{array}{l}\text { Standard } \\
\text { Deviation }\end{array}$ & Net Exposure & $\begin{array}{l}\text { Adjusted } \\
\text { Net } \\
\text { Exposure }\end{array}$ & $\begin{array}{c}\text { Route } \\
\text { Number }\end{array}$ \\
\hline 925 & August 11, 2003 & 12:00:00 PM & 256.40 & 13.85 & 1.23 & 241.33 & 241.33 & 1 \\
\hline 926 & August 11, 2003 & 11:58:00 AM & 256.90 & 13.85 & 1.23 & 241.83 & 241.83 & 1 \\
\hline 927 & February 17, 2003 & 3:54:00 AM & 262.40 & 13.44 & 1.46 & 247.50 & 247.50 & 1 \\
\hline 928 & May 15, 2003 & 7:26:00 PM & 264.60 & 13.81 & 1.25 & 249.54 & 249.54 & 1 \\
\hline 929 & April 29, 2003 & 8:02:00 AM & 266.20 & 13.71 & 1.32 & 251.16 & 251.16 & 6 \\
\hline 930 & June 19, 2003 & 6:00:00 AM & 274.60 & 13.90 & 1.50 & 259.20 & 259.20 & 2 \\
\hline 931 & May 22, 2003 & 6:28:00 AM & 276.50 & 13.72 & 1.75 & 261.03 & 261.03 & 5 \\
\hline 932 & August 30, 2003 & 10:40:00 AM & 435.00 & 15.13 & 25.36 & 394.51 & 394.51 & 5 \\
\hline 933 & August 27, 2003 & 4:32:00 PM & 470.10 & 15.13 & 28.15 & 426.82 & 426.82 & 6 \\
\hline 934 & August 11, 2003 & 1:58:00 PM & 450.20 & 13.85 & 1.23 & 435.13 & 435.13 & 6 \\
\hline 935 & March 16, 2003 & $11: 34: 00$ AM & 459.10 & 13.77 & 1.21 & 444.12 & 444.12 & 6 \\
\hline 936 & October 27, 2003 & $9: 40: 00$ AM & 475.80 & 13.59 & 1.09 & 461.12 & 461.12 & 6 \\
\hline 937 & July 20,2003 & 3:00:00 PM & 496.20 & 13.86 & 1.25 & 481.10 & 481.10 & 6 \\
\hline 938 & April 3, 2003 & 8:12:00 AM & 500.00 & 13.67 & 1.86 & 484.47 & 484.47 & 6 \\
\hline 939 & May 22, 2003 & $6: 26: 00 \mathrm{AM}$ & 500.00 & 13.72 & 1.75 & 484.53 & 484.53 & 6 \\
\hline 940 & March 30, 2003 & 12:10:00 PM & 505.20 & 13.32 & 1.01 & 490.87 & 490.87 & 6 \\
\hline 941 & August 4, 2003 & 4:16:00 AM & 514.40 & 13.64 & 1.22 & 499.54 & 499.54 & 6 \\
\hline 942 & August 10, 2003 & 9:52:00 AM & 523.70 & 13.75 & 1.51 & 508.45 & 508.45 & 6 \\
\hline 943 & June 15, 2003 & 4:40:00 PM & 528.00 & 13.88 & 1.23 & 512.89 & 512.89 & 6 \\
\hline 944 & April 6, 2003 & $11: 08: 00$ AM & 548.50 & 13.68 & 1.25 & 533.57 & 533.57 & 6 \\
\hline 945 & March 3, 2003 & 8:50:00 AM & 569.90 & 13.76 & 1.23 & 554.90 & 554.90 & 6 \\
\hline 946 & August 17, 2003 & 2:00:00 PM & 629.50 & 13.90 & 1.29 & 614.30 & 614.30 & 6 \\
\hline 947 & September 21, 2003 & 11:06:00 AM & 643.70 & 13.90 & 1.07 & 628.73 & 628.73 & 6 \\
\hline 948 & April 6, 2003 & $11: 14: 00 \mathrm{AM}$ & 648.70 & 13.68 & 1.25 & 633.77 & 633.77 & 6 \\
\hline 949 & June 9, 2003 & $10: 32: 00 \mathrm{AM}$ & 694.10 & 13.80 & 1.06 & 679.24 & 679.24 & 6 \\
\hline 950 & October 28, 2003 & $8: 34: 00$ AM & 722.00 & 13.73 & 1.30 & 706.97 & 706.97 & 6 \\
\hline 951 & September 15, 2003 & 5:40:00 PM & 738.00 & 13.85 & 1.44 & 722.70 & 722.70 & 6 \\
\hline 952 & October 19, 2003 & $10: 40: 00 \mathrm{AM}$ & 759.00 & 13.63 & 1.21 & 744.16 & 744.16 & 6 \\
\hline 953 & August 25, 2003 & $11: 38: 00 \mathrm{AM}$ & 763.00 & 13.84 & 2.00 & 747.16 & 747.16 & 6 \\
\hline 954 & February 18, 2003 & 1:28:00 PM & 765.00 & 13.47 & 1.40 & 750.14 & 750.14 & 6 \\
\hline 955 & June 10, 2003 & $6: 36: 00$ AM & 1000.00 & 13.77 & 1.27 & 984.96 & 984.96 & 6 \\
\hline 956 & March 16, 2003 & 1:28:00 PM & 1000.00 & 13.77 & 1.21 & 985.02 & 985.02 & 6 \\
\hline 957 & March 16, 2003 & $11: 32: 00 \mathrm{AM}$ & 1000.00 & 13.77 & 1.21 & 985.02 & 985.02 & 6 \\
\hline
\end{tabular}




\begin{tabular}{|c|c|c|c|c|c|c|c|c|}
\hline $\begin{array}{l}\text { Record } \\
\text { Number }\end{array}$ & Date of Shipment & $\begin{array}{l}\text { Time of } \\
\text { Shipment }\end{array}$ & $\begin{array}{l}\text { Gross } \\
\text { Value }\end{array}$ & $\begin{array}{l}\text { Background } \\
\text { Measurement }\end{array}$ & $\begin{array}{l}\text { Standard } \\
\text { Deviation }\end{array}$ & Net Exposure & $\begin{array}{l}\text { Adjusted } \\
\text { Net } \\
\text { Exposure }\end{array}$ & $\begin{array}{c}\text { Route } \\
\text { Number }\end{array}$ \\
\hline 958 & February 18, 2003 & 6:28:00 AM & 1000.00 & 13.42 & 1.16 & 985.42 & 985.42 & 6 \\
\hline 959 & June 29, 2003 & 5:24:00 PM & 1400.00 & 13.84 & 1.11 & 1385.05 & 1385.05 & 6 \\
\hline 960 & June 8, 2003 & 9:56:00 AM & 1700.00 & 14.01 & 1.24 & 1684.75 & 1684.75 & 6 \\
\hline 961 & June 16, 2003 & $10: 44: 00 \mathrm{AM}$ & 1700.00 & 13.81 & 1.14 & 1685.05 & 1685.05 & 6 \\
\hline 962 & February 25, 2003 & 3:40:00 PM & 1900.00 & 13.98 & 1.35 & 1884.67 & 1884.67 & 6 \\
\hline 963 & June 22,2003 & $11: 44: 00$ PM & 2000.00 & 14.16 & 6.90 & 1978.94 & 1978.94 & 6 \\
\hline 964 & August 3,2003 & $9: 40: 00$ AM & 2000.00 & 14.11 & 4.07 & 1981.81 & 1981.81 & 6 \\
\hline 965 & September 7, 2003 & 7:28:00 AM & 2000.00 & 13.92 & 2.51 & 1983.57 & 1983.57 & 6 \\
\hline 966 & March 11, 2003 & $6: 28: 00$ AM & 2000.00 & 13.77 & 2.56 & 1983.67 & 1983.67 & 6 \\
\hline 967 & September 14, 2003 & $10: 24: 00 \mathrm{AM}$ & 2000.00 & 13.77 & 1.52 & 1984.71 & 1984.71 & 6 \\
\hline 968 & August 10, 2003 & $11: 10: 00 \mathrm{AM}$ & 2000.00 & 13.75 & 1.51 & 1984.75 & 1984.75 & 6 \\
\hline 969 & February 26, 2003 & 7:52:00 AM & 2000.00 & 13.88 & 1.27 & 1984.85 & 1984.85 & 6 \\
\hline 970 & June 22, 2003 & 3:12:00 PM & 2000.00 & 13.83 & 1.28 & 1984.89 & 1984.89 & 6 \\
\hline 971 & June 22, 2003 & 9:18:00 AM & 2000.00 & 13.83 & 1.28 & 1984.89 & 1984.89 & 6 \\
\hline 972 & March 11, 2003 & 1:06:00 PM & 2000.00 & 13.80 & 1.28 & 1984.92 & 1984.92 & 6 \\
\hline 973 & July 10,2003 & 7:10:00 PM & 2000.00 & 13.91 & 1.15 & 1984.94 & 1984.94 & 6 \\
\hline 974 & March 3, 2003 & 12:16:00 PM & 2000.00 & 13.76 & 1.23 & 1985.00 & 1985.00 & 5 \\
\hline 975 & October 6, 2003 & 9:10:00 AM & 2000.00 & 13.87 & 1.11 & 1985.02 & 1985.02 & 6 \\
\hline 976 & October 5, 2003 & 5:18:00 PM & 2000.00 & 13.83 & 1.11 & 1985.06 & 1985.06 & 6 \\
\hline 977 & November 3, 2003 & 7:38:00 AM & 2000.00 & 13.48 & 1.40 & 1985.12 & 1985.12 & 6 \\
\hline 978 & December 7, 2003 & 9:28:00 AM & 2000.00 & 13.59 & 1.24 & 1985.17 & 1985.17 & 6 \\
\hline 979 & December 16, 2003 & $6: 50: 00 \mathrm{AM}$ & 2000.00 & 13.21 & 1.62 & 1985.17 & 1985.17 & 6 \\
\hline 980 & December 16, 2003 & $6: 56: 00 \mathrm{AM}$ & 2000.00 & 13.21 & 1.62 & 1985.17 & 1985.17 & 6 \\
\hline 981 & November 9, 2003 & 9:22:00 AM & 2000.00 & 13.40 & 1.16 & 1985.44 & 1985.44 & 6 \\
\hline 982 & September 11, 2003 & 1:54:00 PM & 2500.00 & 13.90 & 4.68 & 2481.42 & 2481.42 & 6 \\
\hline 983 & August 7,2003 & 3:28:00 AM & 2500.00 & 13.59 & 1.26 & 2485.15 & 2485.15 & 6 \\
\hline 984 & August 30, 2003 & 9:50:00 PM & 2708.16 & 15.02 & 29.25 & 2663.89 & 2663.89 & 6 \\
\hline 985 & September 4, 2003 & 7:22:00 AM & 2708.16 & 13.89 & 3.84 & 2690.43 & 2690.43 & 6 \\
\hline 986 & September 28, 2003 & $10: 34: 00 \mathrm{AM}$ & 2708.16 & 13.99 & 1.21 & 2692.96 & 2692.96 & 6 \\
\hline 987 & December 7, 2003 & $12: 36: 00 \mathrm{PM}$ & 2708.16 & 13.59 & 1.24 & 2693.33 & 2693.33 & 6 \\
\hline 988 & June 20, 2003 & 7:54:00 AM & 3000.00 & 14.02 & 5.38 & 2980.60 & 2980.60 & 6 \\
\hline 989 & September 15, 2003 & 2:56:00 PM & 3000.00 & 13.85 & 1.44 & 2984.70 & 2984.70 & 6 \\
\hline 990 & March 3, 2003 & $10: 52: 00 \mathrm{AM}$ & 3000.00 & 13.76 & 1.23 & 2985.00 & 2985.00 & 6 \\
\hline
\end{tabular}




\begin{tabular}{|c|c|c|c|c|c|c|c|c|}
\hline $\begin{array}{l}\text { Record } \\
\text { Number }\end{array}$ & Date of Shipment & $\begin{array}{l}\text { Time of } \\
\text { Shipment }\end{array}$ & $\begin{array}{l}\text { Gross } \\
\text { Value }\end{array}$ & $\begin{array}{l}\text { Background } \\
\text { Measurement }\end{array}$ & $\begin{array}{l}\text { Standard } \\
\text { Deviation }\end{array}$ & Net Exposure & $\begin{array}{l}\text { Adjusted } \\
\text { Net } \\
\text { Exposure }\end{array}$ & $\begin{array}{c}\text { Route } \\
\text { Number }\end{array}$ \\
\hline 991 & July 13, 2003 & 10:52:00 AM & 3000.00 & 13.91 & 1.07 & 2985.02 & 2985.02 & 6 \\
\hline 992 & September 21, 2003 & 1:10:00 PM & 3000.00 & 13.90 & 1.07 & 2985.03 & 2985.03 & 6 \\
\hline 993 & September 21, 2003 & 12:58:00 PM & 3000.00 & 13.90 & 1.07 & 2985.03 & 2985.03 & 6 \\
\hline 994 & July 14, 2003 & 8:06:00 PM & 3149.70 & 13.90 & 3.26 & 3132.54 & 3132.54 & 6 \\
\hline 995 & July 27, 2003 & 11:20:00 AM & 3500.00 & 13.83 & 1.15 & 3485.02 & 3485.02 & 5 \\
\hline 996 & November 23, 2003 & 11:58:00 AM & 3500.00 & 13.15 & 1.16 & 3485.69 & 3485.69 & 6 \\
\hline 997 & September 28, 2003 & 4:52:00 PM & 4000.00 & 13.99 & 1.21 & 3984.80 & 3984.80 & 6 \\
\hline 998 & July 21, 2003 & $11: 52: 00 \mathrm{AM}$ & 4000.00 & 13.96 & 1.22 & 3984.81 & 3984.81 & 6 \\
\hline 999 & July 20, 2003 & 2:04:00 PM & 4000.00 & 13.86 & 1.25 & 3984.90 & 3984.90 & 6 \\
\hline 1000 & July 20, 2003 & 6:04:00 PM & 4000.00 & 13.86 & 1.25 & 3984.90 & 3984.90 & 6 \\
\hline 1001 & August 24, 2003 & 10:18:00 AM & 4000.00 & 13.73 & 1.12 & 3985.15 & 3985.15 & 6 \\
\hline 1002 & August 24, 2003 & 6:52:00 PM & 4000.00 & 13.73 & 1.12 & 3985.15 & 3985.15 & 6 \\
\hline 1003 & July 29, 2003 & 5:26:00 PM & 4500.00 & 13.92 & 1.27 & 4484.81 & 4484.81 & 6 \\
\hline 1004 & July 29, 2003 & 5:30:00 PM & 4500.00 & 13.92 & 1.27 & 4484.81 & 4484.81 & 6 \\
\hline 1005 & August 14, 2003 & $10: 52: 00 \mathrm{AM}$ & 4500.00 & 13.82 & 1.30 & 4484.87 & 4484.87 & 6 \\
\hline 1006 & September 9, 2003 & 5:32:00 PM & 5000.00 & 13.90 & 1.48 & 4984.62 & 4984.62 & 6 \\
\hline 1007 & October 19, 2003 & 1:30:00 PM & 5000.00 & 13.63 & 1.21 & 4985.16 & 4985.16 & 6 \\
\hline 1008 & August 29, 2003 & $10: 32: 00 \mathrm{AM}$ & 6500.00 & 13.71 & 1.14 & 6485.15 & 6485.15 & 6 \\
\hline 1009 & May 20, 2003 & 6:56:00 AM & 7000.00 & 13.72 & 1.50 & 6984.78 & 6984.78 & 6 \\
\hline 1010 & May 26, 2003 & 9:56:00 PM & 7000.00 & 13.81 & 1.28 & 6984.91 & 6984.91 & 6 \\
\hline 1011 & May 22, 2003 & $6: 24: 00 \mathrm{AM}$ & 10000.00 & 13.72 & 1.75 & 9984.53 & 9984.53 & 6 \\
\hline 1012 & April 8, 2003 & 2:16:00 AM & 12000.00 & 14.76 & 14.31 & 11970.93 & 11970.93 & 6 \\
\hline
\end{tabular}




\section{DISTRIBUTION}

Rick Betteridge

Technology Division

Nevada Site Office

National Nuclear Security Administration

U.S. Department of Energy

P.O. Box 98518

Las Vegas, NV 89193-8518

Martha Youngblood, Contracting Officer

Acquisition Department

Office of Business Services

NNSA Service Center

U.S. Department of Energy

P.O. Box 5400

Albuquerque, NM 87185-5400

Jhon Carilli

Waste Management Division

Nevada Site Office

National Nuclear Security Administration

U.S. Department of Energy

P.O. Box 98518

Las Vegas, NV 89193-8518

James Cebe

Waste Management Division

Nevada Site Office

National Nuclear Security Administration

U.S. Department of Energy

P.O. Box 98518

Las Vegas, NV 89193-8518

Frank Di Sanza

Waste Management Division

Nevada Site Office

National Nuclear Security Administration

U.S. Department of Energy

P.O. Box 98518

Las Vegas, NV 89193-8518

Shirley Doty

Nevada Site Office

National Nuclear Security Administration

U.S. Department of Energy

P.O. Box 98518

Las Vegas, NV 89193-8518
Russ Dwyer (2 copies)

Office of Repository Development

Office of Civilian Radioactive Waste

Management

U.S. Department of Energy

1551 Hillshire Drive

Las Vegas, NV 89134

Dave Emme

Nevada Division of Environmental Protection

Bureau of Waste Management

333 W. Nye Lane, Suite 138

Carson City, NV 89701-0851

Judith A. Holm

Manager, Institutional Programs

Office of National Transportation

Office of Civilian Radioactive Waste Management

U.S. Department of Energy

1000 Independence Ave., SW

Mail Stop RW-30E

Washington, DC 20585

Marjory Jones

Division of Hydrologic Sciences

Desert Research Institute

2215 Raggio Parkway

Reno, NV 89512-1095

Steve Lawrence, Assistant Manager

Site Operations

Nevada Site Office

National Nuclear Security Administration

U.S. Department of Energy

P.O. Box 98518

Las Vegas, NV 89193-8518

Stephen Mellington, Acting Assistant Manager, Environmental Management

Nevada Site Office

National Nuclear Security Administration

U.S. Department of Energy

P.O. Box 98518

Las Vegas, NV 89193-8518 
Kevin Miller

Environmental Measurements Laboratory

U.S. Department of Homeland Security

201 Varick Street, $5^{\text {th }}$ Floor

New York, NY 10014-4811

Michael Nolan, Director

Waste Management Operations

Bechtel Nevada

P.O. Box 98518

Las Vegas, NV 89193-8518

Peter Sanders

Environmental Restoration Division

Nevada Site Office

National Nuclear Security Administration

U.S. Department of Energy

P.O. Box 98518

Las Vegas, NV 89193-8518

David Shafer, Executive Director

Frank H. Rogers Center for Environmental

Remediation and Monitoring

Division of Hydrologic Sciences

Desert Research Institute

755 E. Flamingo Road

Las Vegas, NV 89119-7363

Lee Stevens

Waste Management Division

Nevada Site Office

National Nuclear Security Administration

U.S. Department of Energy

P.O. Box 98518

Las Vegas, NV 89193-8518

Jeff Walker, Director

Office of Technology Development

U.S. Department of Energy

19901 Germantown Road

Germantown, MD 20874

Terry Wallace, Assistant Manager

Technical Services

Nevada Site Office

National Nuclear Security Administration

U.S. Department of Energy

P.O. Box 98518

Las Vegas, NV 89193-8518
Richard Yoshimura

Sandia National Laboratories, New Mexico

P.O. Box 5800

Albuquerque, NM 87185-0718

Nevada State Library and Archives

State Publications

100 North Stewart Street

Carson City, NV 8971-4285

Archives

Getchell Library

University of Nevada, Reno

DeLaMare Library/262

University of Nevada, Reno

Document Section, Library

University of Nevada, Las Vegas

4505 Maryland Parkway

Las Vegas, NV 89154

Library

Stoller-Navarro Joint Venture

7710 W. Cheyenne, Bldg. 3

Las Vegas, NV 89128

ATTN: Toni Miller

Library

Southern Nevada Science Center

Desert Research Institute

755 E. Flamingo Road

Las Vegas, NV 89119-7363

Public Reading Facility

c/o Nuclear Testing Archive

Nevada Site Office

National Nuclear Security Administration

U.S. Department of Energy

P.O. Box 98521

Las Vegas, NV 89193-8521

Technical Library

Nevada Site Office

National Nuclear Security Administration

U.S. Department of Energy

P.O. Box 98518

Las Vegas, NV 89193-8518

Office of Scientific and Technical Information

U.S. Department of Energy

P.O. Box 62 Oak Ridge, TN 37831-9939

(electronic copy) 